Florida International University FIU Digital Commons

\title{
Secondary Stakeholders as Agents of Influence: Three Essays on Political Risk, Reputation and Multinational Performance
}

David A. Wernick

Florida International University, wernick@fiu.edu

DOI: $10.25148 /$ etd.FI11120914

Follow this and additional works at: https://digitalcommons.fiu.edu/etd

\section{Recommended Citation}

Wernick, David A., "Secondary Stakeholders as Agents of Influence: Three Essays on Political Risk, Reputation and Multinational Performance" (2011). FIU Electronic Theses and Dissertations. 538.

https://digitalcommons.fiu.edu/etd/538 


\title{
FLORIDA INTERNATIONAL UNIVERSITY \\ Miami, Florida
}

\begin{abstract}
SECONDARY STAKEHOLDERS AS AGENTS OF INFLUENCE: THREE ESSAYS
ON POLITICAL RISK, REPUTATION, AND MULTINATIONAL PERFORMANCE
\end{abstract}

A dissertation submitted in partial fulfillment of the

requirements for the degree of

DOCTOR OF PHILOSOPHY

in

BUSINESS ADMINISTRATION

by

David Adam Wernick

2011 
To: Dean Joyce Elam

College of Business Administration

This dissertation, written by David Adam Wernick, and entitled Secondary Stakeholders as Agents of Influence: Three Essays on Political Risk, Reputation, and Multinational Performance, having been approved in respect to style and intellectual content, is referred to you for judgment.

We have read this dissertation and recommend that it be approved.

Donald R. Chambers

William Newburry

Isadore Newman

Jennifer Oetzel

William Schneper

Mary Ann Von Glinow

Sumit Kundu, Co-Major Professor

Date of Defense: August 31, 2011

The dissertation of David Adam Wernick is approved.

\begin{tabular}{r} 
Dean Joyce Elam \\
College of Business Administration \\
\hline Dean Lakshmi N. Reddi \\
University Graduate School
\end{tabular}

Florida International University, 2011 


\section{DEDICATION}

I dedicate this dissertation to my family. Without their patience, understanding, encouragement, love, and tremendous sacrifice, this work would not have been possible. 


\section{ACKNOWLEDGMENTS}

I wish to thank the members of my committee for sharing their time, patience, and knowledge with me every step of this journey. This work would have been impossible without their care and commitment. I am profoundly grateful to each of them. I would like extend a particular thank you to my major professor, Dr. Sumit Kundu, who has strongly supported this work from its inception. I also owe a debt of gratitude to Dr. Galen Kroeck and Executive Dean Joyce Elam for their unwavering support throughout my doctoral studies, and to President Mark Rosenberg for being a true friend and mentor. 


\begin{abstract}
OF THE DISSERTATION
SECONDARY STAKEHOLDERS AS AGENTS OF INFLUENCE: THREE ESSAYS

ON POLITICAL RISK, REPUTATION, AND MULTINATIONAL PERFORMANCE

by
\end{abstract}

David Adam Wernick

Florida International University, 2011

Miami, Florida

Professor Sumit Kundu, Major Professor

Organizational researchers have recently taken an interest in the ways in which social movements, non-governmental organizations (NGOs), and other secondary stakeholders attempt to influence corporate behavior. Scholars, however, have yet to carefully probe the link between secondary stakeholder legal action and target firm stock market performance. This is puzzling given the sharp rise in NGO-initiated civil lawsuits against corporations in recent years for alleged overseas human rights abuses and environmental misconduct. Furthermore, few studies have considered how such lawsuits impact a target firm's intangible assets, namely its image and reputation. Structured in the form of three essays, this dissertation examined the antecedents and consequences of secondary stakeholder legal activism in both conceptual and empirical settings.

Essay One argued that conventional approaches to understanding political risk fail to account for the reputational risks to multinational enterprises (MNEs) posed by transnational networks of human rights NGOs employing litigation-based strategies. It offered a new framework for understanding this emerging challenge to multinational corporate activity. Essay Two empirically tested the relationship between the filing of 
human rights-related civil lawsuits and corporate stock market performance using an event study methodology and regression analysis. The statistical analysis performed showed that target firms experience a significant decline in share price upon filing and that both industry and nature of the lawsuit are significantly and negatively related to shareholder wealth. Essay Three drew upon social movement and social identity theories to develop and test a set of hypotheses on how secondary stakeholder groups select their targets for human rights-related civil lawsuits. The results of a logistic regression model offered support for the proposition that MNE targets are chosen based on both interest and identity factors. The results of these essays suggest that legal action initiated by secondary stakeholder groups is a new and salient threat to multinational business and that firms doing business in countries with weak political institutions should factor this into corporate planning and take steps to mitigate their exposure to such risks. 


\section{TABLE OF CONTENTS}

CHAPTER

I. Introduction

ESSAY I - Transnational Legal Activism: A New Form of Political Risk?

II. Abstract and Introduction........................................ 13

III. Literature Review.................................................................. 20

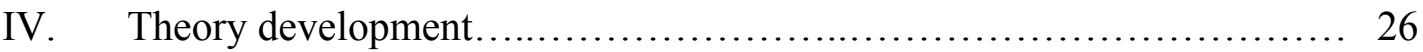

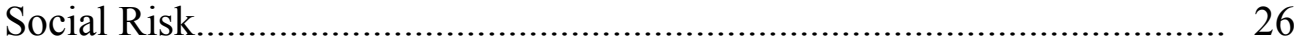

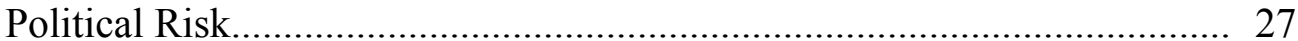

Social vs. Political Risk: Toward a Synthesis.......................................... 30

The 'Human Rights Revolution,' NGOs and the Alien Tort Statute.........31

NGOs as Transnational Advocacy Networks................................34

Extra-Legal Activism........................................... 36

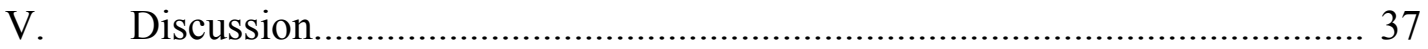

Transnational Legal Risk: A New and Unique Threat to MNEs?.............. 38

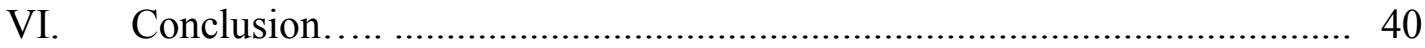

ESSAY II - Secondary Stakeholder Legal Action and Stock Market Performance:

An Event Study of Alien Tort Statue Litigation Filed Against Multinational

Enterprises: 1993-2010

VII. Abstract and Introduction............................................................... 48

The U.S. Legal Environment and Transnational Tort Litigation...... 51

VIII. Literature Review........................................................................ 58

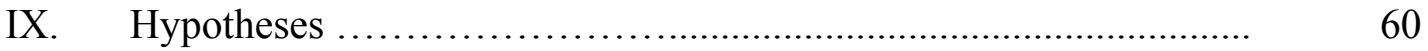

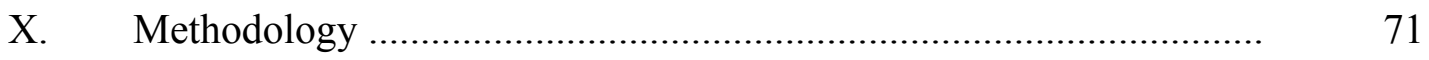

Data Collection Technique …………….............................................. 71

Statistical Analysis............................................................................ 77

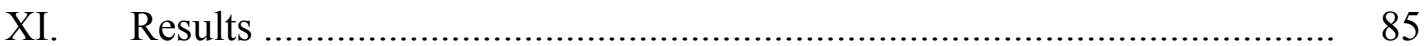

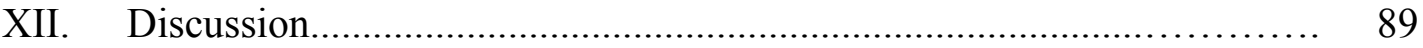

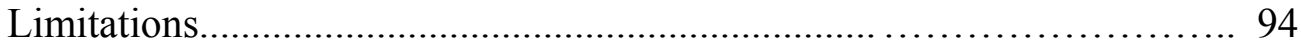


Future Research.

ESSAY III - Is It Who They Are or What They Do? Understanding the Factors that Predict Extractive Firm Vulnerability to Secondary Stakeholder-Initiated Human Rights Litigation

XIII. Abstract and Introduction............................................................ 97

XIV. Theory and Literature Review.................................................... 104

XV. Hypotheses.............................................. 111

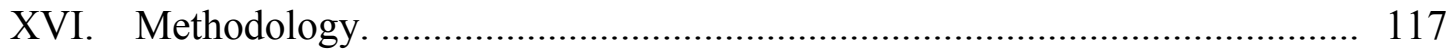

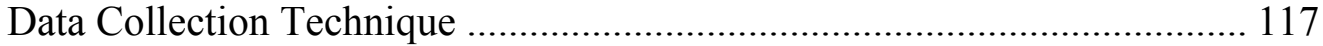

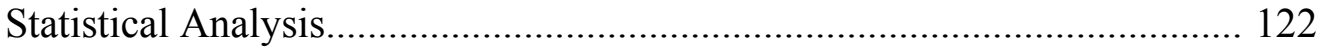

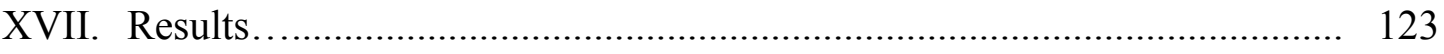

XVIII. Discussion....................................................................... 130

IXX. Conclusion................................................ 133

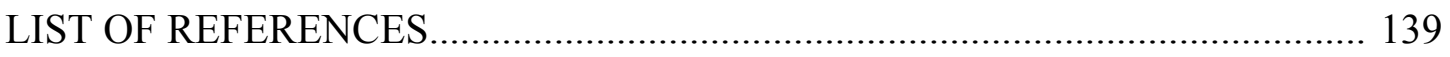

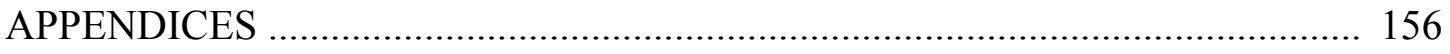

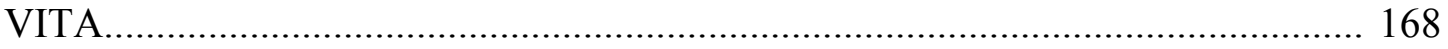




\section{LIST OF TABLES}

TABLE

1. Political, Social, and Transnational Legal Risk: Key Aspects............... 39

2. Descriptive Statistics, Essay Two................................................................ 73

3. Correlation Matrix, Essay Two................................................................. 74

4. Test Statistics for Cumulative Abnormal Returns, Essay Two...............................86

5. Regression Coefficients, Essay Two.................................................... 88

6. Descriptive Statistics for Firms in Combined Sample, Essay Three................... 119

7. Correlation Matrix, Essay Three.......................................................... 124

8. Tolerance Statistics for Independent Variables, Essay Three.............................. 125

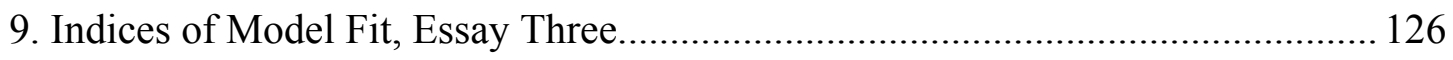

10. Classification Table, Essay Three............................................................ 126

11. Summary of Model Variables, Essay Three............................. 127 


\section{LIST OF FIGURES}

FIGURE

PAGE

1. Conceptual Diagram for the Three Essays.......................... 10

2. Stakeholder Conceptual Diagram, Essay 1........................................... 22

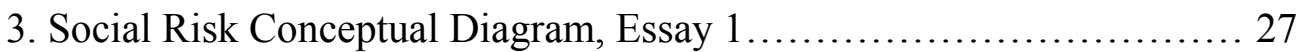

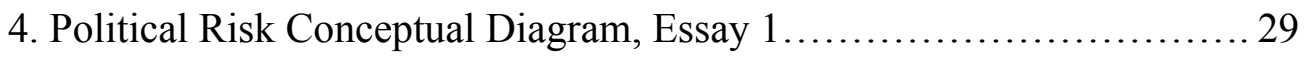

5. ATS Lawsuits by Issue, Essay 2....................................................... 76 


\section{Introduction}

In his seminal book Exit, Voice, and Loyalty (1970) economist Albert O. Hirschman theorized that when confronted with declining performance on the part of an entity with which they have a relationship -- whether a business, government, or political party - individuals and organizations choose to either withdraw from the relationship (i.e., exit), repair it through communication or protest (i.e., voice), or remain quiescent (i.e., loyalty). In recent years sociologists and organizational scholars have invoked Hirschman's framework to explain how social movements, non-governmental organizations (NGOs), and other activist groups use "voice" to promote institutional change (Davis, McAdam, Scott, \& Zald, 2005), and influence corporate policies (King \& Soule, 2007; Rao, 2009).

Hirschman's ideas have had particular resonance with organizational researchers, who have sought to marry his framework with stakeholder theory (King \& Soule, 2007; King, 2008; Eesley \& Lenox, 2006; Lenox \& Eesley, 2009). Stakeholder theory (Freeman, 1984) identifies activist groups as secondary stakeholders, which, unlike primary stakeholders (e.g., shareholders, customers, employees, suppliers, and regulators), have neither a transactional relationship with the firm nor legal authority over it (Clarkson, 1995). Moreover, the firm is not dependent on secondary stakeholders for its survival (Frooman, 1999). As such, these groups should have limited influence over corporate decision-makers, who are typically attuned to the interests and demands of more salient stakeholders - those with power, legitimacy, and urgency (Mitchell, Agle, \& Wood, 1997). And while secondary stakeholders face considerable obstacles in their dealings with corporations (Clarkson, 1995), by skillfully leveraging human resources 
(Yaziji \& Doh, 2009), information technology (Hart \& Sharma, 2004), and relationships with the media, investors, and other stakeholders (Frooman, 1999), they have often been able to advance their agendas (Doh \& Teegen, 2003; Soule, 2009; Spar \& LaMure, 2003; Yaziji \& Doh, 2009).

Meanwhile, since NGOs tend to enjoy high levels of legitimacy (Yaziji, 2004), they have increasingly become highly sought after partners by firms seeking to burnish their images, enhance their reputations, and protect their brand equity (Dahan, Doh, Oetzel, and Yaziji, 2010; Yaziji \& Doh, 2009). Given the proliferation of NGOs in recent years, the growing scope of their activities, and the increasing complexity of the ties between firms and NGOs - both adversarial and cooperative -- a more nuanced understanding of secondary stakeholder activism and its relationship to multinational financial performance is clearly warranted. This dissertation aims to provide such an understanding.

Structured in the form of three essays, this dissertation examines the antecedents and consequences of secondary stakeholder legal activism in both conceptual and empirical settings. Essay One situates the phenomena within the international business and strategy literatures on political risk (Kobrin, 1982; Wells, 1998; Oetzel, 2005), and the sociology-based literature on social risk (Yaziji, 2005; Yaziji \& Doh, 2009). It argues that both frameworks offer important insights into secondary stakeholder legal activism, but that each ultimately falls short in key areas, thereby necessitating new theorizing. It puts forth a new conceptual construct - transnational legal risk - to explain the emerging threat to multinational enterprises (MNEs) posed by transnational human rights networks and offers implications for theory and practice. 
Essay Two empirically tests the relationship between the filing of human-rights related lawsuits and MNE stock market performance. Using an event study methodology and regression analysis, it shows that target firms experience a significant decline in share price upon filing and that both industry and nature of the lawsuit have a significant and negative relationship to shareholder wealth.

Essay Three explores the issue of why certain firms are targeted for anti-corporate campaigns while others escape scrutiny. Drawing upon social movement and social identity theories, the study develops and tests a set of hypotheses on how stakeholder groups select their targets for human-rights related lawsuits. Support is found for the idea that MNE targets are selected based on both interest and identity factors, including social performance and financial performance. Conclusions and implications for practice are drawn.

Essay 1 - Transnational Legal Activism: A New Form of Political Risk?

This essay begins by reviewing two recent cases of North American MNEs that have been targeted by activist groups over alleged misconduct in developing countries Chevron and Talisman Energy. In both cases the companies were sued in U.S. federal courts under a formerly obscure 1789 legal statute known as the Alien Tort Statute (ATS), which allows foreign individuals to file civil lawsuits against former government officials, private individuals, and corporations for serious violations of international law. The ATS has been used since the mid-1990s to sue MNEs, with more than 100 cases filed, involving over 150 corporate defendants (Drimmer, 2010). High-profile ATS cases have involved allegations of MNE support for genocide and ethnic cleansing in Sudan 
(Kobrin, 2005), repression against non-violent protesters occupying an offshore oil platform in Nigeria (Frynas, 2004), aiding and abetting forced labor, torture, rape and other crimes against humanity as part of a natural gas pipeline project in Burma (Spar \& LaMure, 2003), and complicity in extrajudicial killings of trade union leaders at beverage bottling plants and coal mines in Colombia (Shamir, 2004). In addition to contesting these lawsuits inside the courtroom, both Chevron and Talisman have been targeted by activists with boycotts, protests, shareholder resolutions, and other extra-legal tactics. These cases are part of a growing trend of transnational legal activism, instigated by U.S. and European NGOs to pressure MNEs with operations in the developing world particularly large natural resource firms -- to change their business practices and make other concessions (Drimmer, 2010).

But from the firm's perspective, does the prospect of being sued in U.S. courts for alleged human rights violations and other misconduct in foreign countries represent a type of political risk? An argument could certainly be made that it does based on the classical international business (IB) literature on the topic (e.g., Robock, 1971; Kobrin, 1982; Simon, 1984). Yet the political risk literature focuses on governmental actions (e.g., expropriations and discriminatory policies) in the host country as the chief source of firm-level risk (de la Torre \& Neckar, 1988; Henisz \& Zelner, 2003, Wells, 1998), whereas the emerging threat of legal activism emanates primarily from non-governmental actors in the home country or in multiple countries. In addition, the political risk literature tends to focus on the direct operational costs of government interference, whereas the new threat of legal activism involves both direct and indirect costs, such as damage to corporate images, reputations, and brands (Drimmer \& Lamorre, 2011). 
The literature on "social risk" (Yazjij, 2005; Yaziji \& Doh, 2009) calls attention to these indirect costs of activism, as well as the unique pathway in which influence is exerted - from secondary stakeholder groups to the firm via the intermediary of "critical players" (e.g., public pension funds, customers, the media, regulators, the courts, and the general public). Yet the social risk literature, for all its merits, tends to ignore the direct costs of activism and focuses primarily on NGO mobilization in the developed world, rather than mobilization by transnational networks of activist groups spanning multiple nations.

In addition to reviewing and synthesizing these literatures on political and social risk, this first essay provides an overview of the origins and evolution of corporate ATS litigation, along with an analysis of the NGOs that have pioneered its use and the legal and extra-legal tactics they routinely employ to gain leverage over their corporate targets. A new conceptual construct - transnational legal risk - is offered to explain the emerging threat to MNEs posed by these networks. The essay concludes with implications for theory and practice.

Essay 2: Secondary Stakeholder Legal Action and Stock Market Performance: An Event Study of Alien Tort Statue Litigation Filed Against Multinational Enterprises: 1993-2010

A growing body of empirical research has emerged in recent years that examines the relationship between shareholder wealth and stakeholder influence tactics such as boycotts (Pruitt \& Friedman, 1986; King, 2008), protests (Epstein \& Schnietz, 2002; 
King \& Soule, 2007), letter-writing campaigns (Smith \& Cooper-Martin, 1997), divestitures (Davidson, Worrell, \& El-Jelly, 1995), and shareholder (proxy) resolutions (Reid \& Toffel, 2009; Doh, Howton, Howton, \& Siegel, 2010). Yet scholars have devoted scarce attention to empirically measuring the stock market's reaction to stakeholder-initiated civil lawsuits. This is surprising since stakeholder groups are increasingly employing civil litigation as a central pillar of their anti-corporate campaigns (Kurlantzick, 2004). Moreover, one of the few studies to examine corporate response to a variety of stakeholder tactics including civil lawsuits found that they were more likely to elicit concessions than any other tactic (Eesley \& Lenox, 2006).

Given that corporate share price is a widely accepted benchmark for assessing managerial performance, if the filing of civil lawsuits is associated with a loss of shareholder wealth, then managers might have an incentive to engage with stakeholder groups and settle these complaints before they result in litigation, or undertake corporate citizenship initiatives (Gardberg \& Fombrun, 2006) that might make the firm less of a target in the first place. Conversely, if no relationship exists between the filing of these lawsuits and corporate share price, firms might choose to ignore them and let the legal process run its course. Either way, the question of whether secondary stakeholderinitiated litigation is related to corporate share price has great relevance for multinational strategy.

This essay employed an event study methodology to investigate whether the filing of civil lawsuits under the ATS are related to target firm stock price. Research was gathered on all ATS lawsuits filed against MNEs from 1993 to 2010 using Lexis-Nexis and Westlaw legal databases of Federal civil lawsuits. Daily stock price data was 
collected from the CRSP database at the University of Chicago. The study controlled for market-wide fluctuations in stock price returns which could occur for reasons unrelated to the filing of the lawsuits.

Statistical analysis showed that lawsuit filings are significantly and negatively related to target firm share prices during certain event windows. In addition, regression analysis indicated that cases alleging labor violations are associated with a significant loss of shareholder wealth, as are cases involving extractive companies. It was concluded that given the current legal environment, firms with existing investments in developing countries need to be vigilant about monitoring the activities and practices of their overseas subsidiaries and business partners, while firms contemplating major investments should think twice, as some potentially profitable opportunities may be so fraught with risk that they do not merit the investment.

Essay 3: Is It Who They Are or What They Do? Understanding the Factors that Predict Extractive Firm Vulnerability to Secondary Stakeholder-Initiated Human Rights Litigation

Notwithstanding the recent interest amongst organizational scholars in secondary stakeholder activism (Eesley \& Lenox, 2006; Gardberg \& Newburry, 2010; King \& Soule, 2007), the question of why particular firms become targets of activist pressure while others fly below the radar has only received limited attention in the management literature (Whetten, Rands, \& Godfrey, 2002).

Rowley and Moldoveneau (2003) have proposed that anti-corporate activists are driven by two distinct sets of factors: interest-based motivations and identity-based 
motivations. The former pertain to issues these groups hold to be important, including conservation, social justice, and non-discrimination in the workplace. Identity-based factors, by contrast, relate to the organizational imperative to foster solidarity and collective identity. If stakeholder groups are driven primarily by interest-based motivations, they might be expected to target companies in industries that generate negative externalities such as air and water pollution, as well as specific firms perceived to be negligent on social, environmental, and workplace issues. If driven primarily by identity-based motivations, they might be expected to target companies for reasons unrelated to their industry or social performance (Rowley \& Moldoveneau, 2003). A recent review of the empirical literature suggests that "both repeated wrong-doers and larger and more visible firms are at a greater risk of stakeholder scrutiny," thus lending support for both interest-based and identity-based explanations (de Bakker \& den Hond, 2008). Whether this holds true for stakeholder-initiated civil lawsuits, however, remains an unanswered question.

We studied this question by examining lawsuits filed by NGOs against natural resources firms under the ATS. We chose this industry because of its size and importance to the global economy - in 2006, the world's 39 largest publicly listed oil companies generated nearly $\$ 2.8$ trillion in revenue (Rangan \& Barton, 2010) -- and because roughly one-quarter of all the ATS lawsuits filed against MNEs have targeted firms engaged in natural resource extraction or production (Drimmer \& Lamorre, 2011).

Our results suggest that activist groups sometimes choose their corporate targets with the aim of changing the practices of social performance laggards (i.e., based on what they do). But they also indicate that some ATS lawsuits are targeted at highly profitable 
firms, irrespective of their social performance (i.e., based on who they are). It is possible to infer from these results that stakeholder groups are motivated by both interest and identity-based rationales in choosing corporate targets for ATS lawsuits - a finding that is broadly consistent with past empirical research on stakeholder activism (den Hond \& de Bakker, 2007; Rehbein, Waddock \& Graves, 2004).

Conceptual Model for the Three Essays

Figure 1 provides a conceptual diagram that links the three essays that comprise this dissertation. The diagram, viewed from left to right, depicts the pathways of influence and the hypothesized relationships between actors and variables. As can be seen, Essay 3 postulates that secondary stakeholder groups, when considering the universe of potential corporate targets for litigation-based adversarial campaigns, base their decisions, at least in part, on four factors $(\mathrm{H} 1-\mathrm{H} 4)$. Essay 2 considers consequences for firms of being targeted by ATS litigation and other stakeholder actions. It predicts that the filing of ATS litigation will trigger a negative short-term stock market reaction $(\mathrm{H} 1)$, as investors adjust their portfolios in response to the news of the litigation. The magnitude of the stock market's reaction, it is further hypothesized, will be affected by a series of firm and stakeholder factors (H2 - H6). Finally, Essay 1 provides an integrative theoretical and conceptual framework for the three essays. 
Figure 1: Conceptual Model for the Three Essays

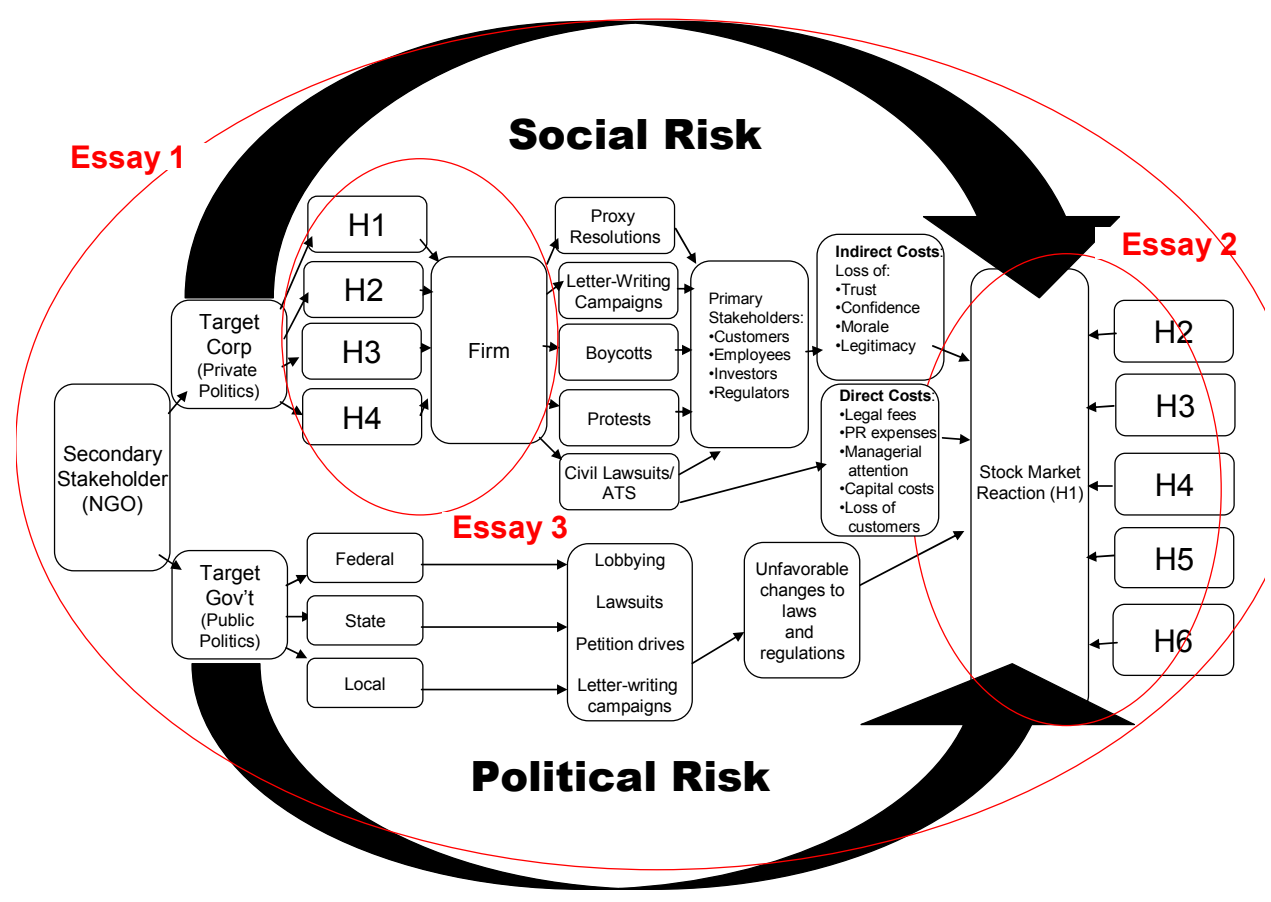

Contribution

This dissertation has relevance for theory, practice, and public policy. By examining how an increasingly influential group of secondary stakeholders - human rights activists - are using civil litigation and extra-legal tactics to press for concessions from MNEs, we offer new insights into a phenomenon that has great salience for IB and management scholars. Given the dearth of scholarly analysis on this topic in the core management literature in comparison to other anti-corporate tactics such boycotts, protests, and proxy resolutions, this work fills an important void.

In a broader sense, this research contributes to the scholarly effort to understand how a range of relatively resource-poor, powerless, and marginalized groups (Gardberg 
\& Newburry, 2010) are using "voice" (Hirschman, 1970) to challenge corporate policies and practices, promote institutional change, and press for new and binding global norms governing the conduct of international business. These groups include NGOs (Doh \& Teegen, 2003; Yaziji \& Doh, 2009), social movements (King \& Soule, 2007; King, 2008; Soule, 2009), and transnational advocacy networks (Riesse et al., 1999). Meanwhile, by identifying the factors that underlie the targeting decisions of NGOs initiating ATS legal challenges against MNEs and empirically testing their impact on stock market performance, this research addresses the gap in our knowledge of the motives and tactical choices stakeholders make and their firm-level consequences (de Bakker \& den Hond, 2008), thereby advancing stakeholder theory.

This research also has relevance for practice. Given the sharp rise in human-rights related lawsuits against MNEs in recent years, managers need to have a better understanding of the likelihood and costs (both direct and indirect) of litigation prior entering new markets. Our principal findings that the filing of ATS lawsuits has a significant and negative relationship to shareholder wealth and that stakeholder groups select their targets for ATS litigation based in part on their social performance would seem to provide a strong justification for multinational managers to seek ways to improve their overseas business practices and stakeholder relations. Possible avenues for action include pursuing dialogue with activists (Hart \& Sharma, 2004), adopting voluntary codes of conduct (Drimmer \& Lamorree, 2011), joining private certification schemes (Conroy, 2007; Vogel, 2008), embracing cross-sectoral partnerships with NGOs (Dahan et al., 2010), and undertaking other corporate citizenship initiatives (Gardberg \& Fombrun, 2006). 
From a policy standpoint, the sharp rise in foreign direct investment to emerging markets in recent years has been heralded as a promising development in global economic affairs (Khanna \& Palepu, 2010). But if MNEs perceive the legal risks in these markets to be too great, they may scale back their investments or withdraw entirely, with grave consequences for local development. Moreover, the exit of Western MNEs from countries with weak governing institutions could diminish Western strategic influence in countries regarded as important partners in the struggle against international terrorism (Shamir, 2004), and open the door to state-owned firms from emerging nations that are less beholden to pressures from civil society and less committed to social responsibility (Schrage, 2003).

This research suggests that the concerns of business and political leaders are legitimate. But so too are the concerns of activist groups that have called attention to the growing disparity in economic power between MNEs and their developing country hosts, and the historic ability of these firms to influence (and sometimes subvert) local laws and regulations while evading responsibility for grievous crimes committed on their behalf or in their interests by sovereign governments. In the absence of a new and binding global framework that spells out the specific social responsibilities and moral obligations of MNEs operating in developing countries, private efforts by transnational activist networks to hold them accountable for overseas rights abuses are bound to continue, with major ramifications for firms that do international business, and the governments and citizens of the nations where they do it. 


\section{Essay I - Transnational Legal Activism: A New Form of Political Risk?}

\section{Abstract and Introduction}

Business scholars have recently taken an interest in the ways in which social movements, non-governmental organizations, and other secondary stakeholder groups attempt to influence corporate policies and practices through confrontational tactics such as boycotts and protests. Yet few efforts have been made to conceptualize the relationship between social activists and the firms they seek to influence, and the mechanisms by which these groups exert their influence remain poorly understood. This essay seeks to fill this gap by examining how transnational networks of human rights activists have used extraterritorial civil litigation and extra-legal activism to push for concessions from multinational enterprises. Building upon stakeholder theory, international business theories of political risk, and neo-institutional theories of social risk, we offer a new conceptualization. Implications for theory and practice are discussed.

In his seminal book Exit, Voice, and Loyalty (1970), Albert O. Hirschman theorized that when confronted with declining performance on the part of an entity with which they have a relationship -- whether a business, government, or political party individuals and organizations chose to either withdraw from the relationship (i.e., exit), attempt to repair it through communication or protest (i.e., voice), or remain quiescent (i.e., loyalty). In recent years sociologists and organization scholars have invoked Hirschman's exit, voice, loyalty framework to explain how social movements, nongovernmental organizations (NGOs), and other relatively powerless groups use "voice" 
to influence corporate policies (King \& Soule, 2007; King, 2008) and promote institutional change (Davis, McAdam, Scott, \& Zald, 2005; Rao, 2009).

Hirschman's ideas have influenced the work of Baron (2001, 2003), who has coined the term "private politics" to refer to social activism aimed directly at corporations rather than channeled via the intermediary of the state (i.e., public politics). Examples of private political activity include boycotts, protests, civil lawsuits, and shareholder (proxy) resolutions, ${ }^{1}$ whereas lobbying legislators and regulators and seeking favorable judicial interpretations represent public political activities (Baron, 2001, 2003; Reid \& Toffel, 2009). ${ }^{2}$ While private political activity in the U.S. has a long history that dates back at least to the Boston Tea Party, ${ }^{3}$ it has become increasingly common in recent years, spurred by the growing economic power of multinational enterprises (MNEs) and the

\footnotetext{
${ }^{1}$ Pioneered by religious organizations, proxy resolutions are often initiated by activist groups who buy enough shares of a company's stock (the equivalent of $\$ 2,000$ ) to initiate a vote on their resolutions at annual shareholder meetings. An example is People for the Ethical Treatment of Animals (PETA), which has reportedly purchased shares in at least 80 companies in recent years, including McDonald's and Kraft Foods, in order to file proxy resolutions (Crumb, 2010).

${ }^{2}$ Activist groups often pursue private and public political strategies simultaneously. A prime example is the student-based Free Burma Coalition, which, during its heyday in the late 1990s, combined anti-corporate activism, including protests, boycotts, and shareholder resolutions, with appeals to local, state and federal governments for sanctions and selective purchasing laws (Spar \& LaMure, 2003).

${ }^{3}$ As King (2009) observes, the Boston Tea Party was both a protest against Britain's rule over its North American colonies and a tactic designed to generate outrage about the East India Tea Company, which was using its market power to drive smaller American rivals out of business. The current era of private political activity directed against MNEs began with the boycott of Nestle in the late 1970s over its sale of infant formula in developing countries (Davis, Morrill, Rao, \& Soule, 2008).
} 
diminished ability of states to rein them in through regulation (King \& Pearce, 2010), and the proliferation of NGOs (Doh \& Teegen, 2003; Yaziji \& Doh, 2009). ${ }^{4}$

NGOs have been defined as private, not-for-profit organizations that aim to serve particular societal interests by focusing on advocacy and/or operational efforts on social, political and economic goals, including equity, education, health, environmental protection and human rights (Teegen et al., 2004). These groups pressure corporations to meet their demands through "insider" and "outsider" strategies (Peterson, 1992). The former involve efforts to influence decision makers directly, typically through moral suasion; the latter, indirectly, by mobilizing public opinion (Peterson, 1992). Outsider strategies often involve adversarial "market campaigns" that threaten (and deliver) harm to corporate reputations and brands (Klein, 2000; Baron and Diermeier, 2007; O'Rourke, 2005). These market campaigns have grown in scope and sophistication in recent years (Manheim, 2001; Drimmer, 2010), and now frequently transcend national borders, creating new risks for MNEs (Spar \& LaMure, 2003; Kobrin, 2005).

A case in point is the campaign waged against Chevron for alleged environmental damage caused by Texaco (acquired by Chevron in 2001) during the nearly three decades it operated a petroleum concession in Ecuador's Oriente region. ${ }^{5}$ Spearheaded by the Amazon Defense Fund (ADF), an Ecuadorian NGO that describes itself as "part of a

\footnotetext{
${ }^{4}$ As Yaziji and Doh (2009) observe, the number of NGOs around the world has grown by 400 percent over the last decade, while mentions of NGOs in the Financial Times and the Wall Street Journal have risen twenty-fold over this period.

${ }^{5}$ Texaco subsidiary TexPet acquired the right to explore and drill for oil in Ecuador in 1964. It operated as part of various consortia with private and state partners until 1992, when it sold its assets to PetroEcuador, the state-owned oil company (Drimmer, 2010).
} 
regional, national, and global struggle for environmental and collective rights in the Ecuadorian Amazon," the campaign began in the early 1990s with a lawsuit filed in a U.S. district court claiming violations of the Alien Tort Statute (ATS) (Aguinda v. Texaco, Inc.), a law that permits non-U.S. citizens to sue corporations in U.S. federal courts for overseas human rights violations (Davis, 2008). ${ }^{6}$ The lawsuit was filed on behalf of 30,000 indigenous people from Ecuador by U.S. and foreign NGOs, public interest attorneys, a Philadelphia-based class action law firm, and several Boston-based law professors (Shamir, 2004). The plaintiffs claimed that Texaco improperly disposed of toxic oil by-products, contaminating rivers and streams, and causing widespread illness. ${ }^{7}$

While the ATS lawsuit was dismissed by a U.S. court in 1996 under forum non conveniens, a legal doctrine that requires a court to dismiss a case if a more appropriate alternative forum exists, related charges were brought in Ecuador under local law. Years of costly litigation ensued. Meanwhile, activists launched a multi-pronged grassroots effort in the U.S. aimed at damaging the firm's image with customers and investors. The campaign, which continues to this day, has included a sophisticated media and public relations effort built around a web-based portal (chevrontoxico.com) containing news items, fact sheets, press kits, court documents, and multimedia clips, and an investor outreach effort that has involved filing shareholder resolutions critical of the company's

\footnotetext{
${ }^{6}$ The ATS, part of the U.S. Judiciary Act of 1789, states that "The district courts shall have original jurisdiction of any civil action by an alien for a tort only, committed in violation of the law of nations or a treaty of the United States."

${ }^{7}$ The Plaintiffs charged Texaco with dumping 18.5 billion gallons of "formation water" - leftover water from the oil extraction process - into open pits that fed into waterways. The result was massive ecological damage, elevated rates of cancer for local residents, and other health issues (Kolker, 2006).
} 
environmental practices and direct appeals to large public pension funds urging them to liquidate their Chevron stock. ${ }^{8}$ The activists achieved a stunning victory in 2011 when an Ecuadorian court found the firm liable for $\$ 17$ billion in damages - the largest-ever award of its kind -- and ordered the MNE to pay an additional 10 percent of the value of the compensatory damages (roughly $\$ 860$ million) to the $\mathrm{ADF} .{ }^{9}$

Another prominent case of private politics involves Canadian oil and gas producer Talisman Energy, which was targeted by activists in the late 1990s after acquiring a smaller Canadian firm with investments in Sudan (Manhas, 2007). Like the campaign against Chevron, the centerpiece of Talisman campaign was a lawsuit: a $\$ 1$ billion class action lawsuit filed in a U.S. federal court charging the firm with complicity in genocide and war crimes perpetrated by the Sudanese government against Christians and other non-Muslim minorities (Kobrin, 2004). In addition to aiding the repressive regime in Khartoum with royalties from an oil pipeline it helped operate, Talisman was accused of providing fuel, vehicles, aircraft, and runways for the Sudanese military, which used them to carry out bombing raids on civilians (Shamir, 2004). Other elements of the divestment campaign, led by the American Anti-Slavery Group, a Boston-based NGO, included boycotts, protests, and proxy resolutions. The campaign generated a barrage of negative press and prompted large investment funds including TIAA-CREF, CALPERS,

\footnotetext{
${ }^{8}$ A novel element of the anti-Chevron campaign is the feature-length documentary "Crude," produced by an independent filmmaker at the suggestion of one of the plaintiffs' attorneys, which features interviews with villagers supposedly harmed by the firm's environmental malpractice and cameo appearances by celebrities such as musician Sting and his wife Trudi Styler (Drimmer, 2010).

${ }^{9}$ Chevron has appealed the judgment, claiming that the ruling was the "product of fraud and contrary to the legitimate scientific evidence" and filed a counter-lawsuit in the U.S. against the plaintiffs' attorneys for violations of the Racketeer Influenced and Corrupt Organizations Act (RICO) (Barrett, 2011).
} 
and the New York City Pension Fund to sell their Talisman shares. The U.S. Congress also considered legislation that might have resulted in Talisman's shares being delisted from the New York Stock Exchange (Kobrin, 2004). Talisman ultimately succumbed to pressure and sold off its Sudanese assets in late 2002, citing "shareholder fatigue" (Manhas, 2007).

The campaigns against Chevron and Talisman, and others like them, suggest a new dynamic in business-society relations, wherein activist groups are leveraging resources and networks across countries and using both legal and extra-legal tactics to pressure firms to divest from otherwise profitable ventures, alter their business practices, and improve their social and environmental performance. In addition, some activist groups appear bent on instigating sweeping institutional changes to entire industries (Reid \& Toffel, 2009) and establishing binding new global norms governing MNE conduct in developing countries (Shamir, 2004). Tarrow (2005) refers to this as "the new transnational activism," which he sees as being driven by "rooted cosmopolitans" -individuals with local and international networks and resources that they use to advance claims on behalf of external actors. In a similar vein, other scholars herald the emergence of "transnational advocacy networks" (Risse et al., 1999), "transnational social movements" (Smith et al., 1997), and "activism beyond borders" (Keck and Sikkink, 1998).

But to what extent is the emerging threat to international business (IB) posed by these activist networks new and different from past threats that MNEs have confronted? How should IB and Strategy scholars conceptualize this threat? And what are the risk management implications? For Jones (2010), transnational legal activism of the kind 
practiced against Chevron and Talisman represents a "new form of political risk." It is "new" in the sense that it stems from changes in international legal norms that have made MNEs potentially liable in the home country for the misconduct of foreign governments, security forces, and even paramilitary organizations if it can be proven that the firm's managers knew about this misconduct or somehow benefitted from it (Davis, 2008). Yet in other respects, this threat is not all that different from the types of challenges MNEs operating in developing countries have faced for years. Indeed, Simon (1984), who put forth an influential conceptual model of political risk, included unfavorable legal rulings in the MNE's home country within his model, categorizing these as "direct external risks" to operations and profitability. ${ }^{10}$

Yet the political risk literature, by and large, focuses on governmental action (or inaction) in the host country as the source of firm-level risk (Wells, 1998), whereas the emerging threat of transnational legal activism emanates from NGOs typically domiciled in the home country or in multiple countries. Indeed, as Kobrin (2005: 204-205) writes, what drove Talisman from Sudan, "was not in-country risk: they managed a difficult situation well... Rather, Talisman sold its Sudanese operations because of 'political risks' arising in North America from activists' successful efforts to associate it with complicity in human rights violations in Sudan."

Yaziji (2005) offers a different label for this emerging threat: "social risk," which he defines as "exposure to possible loss or constraints on strategic choice resulting from

\footnotetext{
${ }^{10}$ By contrast, unfavorable legal rulings in the host country, along with expropriations, restrictions on remittances, wage and price controls, and other discriminatory actions represented "direct-internal risks," which emanate from the host government (Simon, 1984).
} 
normative delegitimation challenges by external organizations." Drawing upon neoinstitutional theory (Scott, 2001; Suchman, 1995), he calls attention to the indirect costs to firms of stakeholder activism, which may include the loss of brand value, employee morale, and legitimacy with key stakeholders. It is these costs, he argues, that ultimately drive the managers of targeted firms to respond to the demands of activist groups, which otherwise wouldn't receive much attention.

But does either of these frameworks adequately explain the nature of the threat to MNEs posed by transnational legal activism and the mechanisms by which such influence is exerted? This essay argues that both frameworks offer important insights into this emerging threat but that each ultimately falls short in key areas, thereby necessitating new theorizing.

This paper proceeds as follows: First we review the literature on secondary stakeholder activism. Next, we examine existing theories of political and social risk. We then provide a brief overview of the ATS, followed by an analysis of the NGOs that have pioneered its use and the legal and extra-legal tactics they routinely employ to gain leverage over their corporate targets. We then put forth a new conceptual construct transnational legal risk - to explain the emerging threat to MNEs posed by these networks and conclude with implications for theory and practice.

\section{Literature Review}

Numerous observers have noted that the once adversarial relationship between NGOs and corporations appears to have evolved into a new and more complex relationship that often involves elements of collaboration, dialogue, and partnership 
(Doh, Newburry, \& Teegen, 2003; Rondinelli \& London, 2003; Yaziji \& Doh, 2009).

One indicator of the new spirit of cooperation is the proliferation of cross-sectoral partnerships like those forged between McDonald's and the Environmental Defense Fund to eliminate polystyrene packaging and reduce solid waste (Davis et al., 2008), and Unilever and Oxfam International to reduce poverty and promote economic development in Indonesia (Yaziji \& Doh, 2009). Research suggests that corporations and stakeholder groups can both derive significant benefit from these partnerships. NGOs may obtain financial and technical resources that enable them to better serve their members and maximize their social impact, while firms may gain enhanced social legitimacy (LaFrance \& Lehaman, 2005), technical and legal expertise (Yaziji, 2004), and access to new information about consumer trends that leads to innovative new products, services, and business models (Dahan et al., 2010; Hart \& Sharma, 2004; Yaziji, 2004).

And while cooperation between NGOs and corporations is on the rise, confrontation remains a key leitmotif of the relationship - particularly when the NGO possesses a radical, anti-corporate ideology (den Hond \& de Bakker, 2007). Management and organization researchers seeking to understand the interplay between activist groups and corporations have recently employed stakeholder theory (Freeman, 1984) as a theoretical lens (Laplume, Sonpar, \& Litz, 2008). A stakeholder is "any group or individual who can affect or is affected by the achievement of the organization's objectives (Freeman, 1984: 46).” In contrast to the shareholder perspective, which views profit maximization as the sole objective of the corporation (Friedman, 1962), stakeholder theory views the economic goals of the corporation to be less important than organizational survival, which can be enhanced by cultivating strong relationships with a 
wide array of groups with a stake in the corporation, including employees, customers, suppliers, creditors, and communities, as well as shareholders (Soule, 2009).

Stakeholder theory accords NGOs and social movements the status of secondary stakeholders (Clarkson, 1995). Unlike the primary stakeholders of the company (e.g., shareholders, workers, suppliers, and creditors), secondary stakeholders have no contractual bond to the firms they seek to influence, little resource leverage, and are less vital to organizational survival (Clarkson, 1995; Eesley \& Lenox, 2006). In conceptual terms, they are part of an outer ring of stakeholder "spokes" that encircle a "hub," which represents the firm. See Figure 2.

Figure 2: Stakeholder Conceptual Diagram

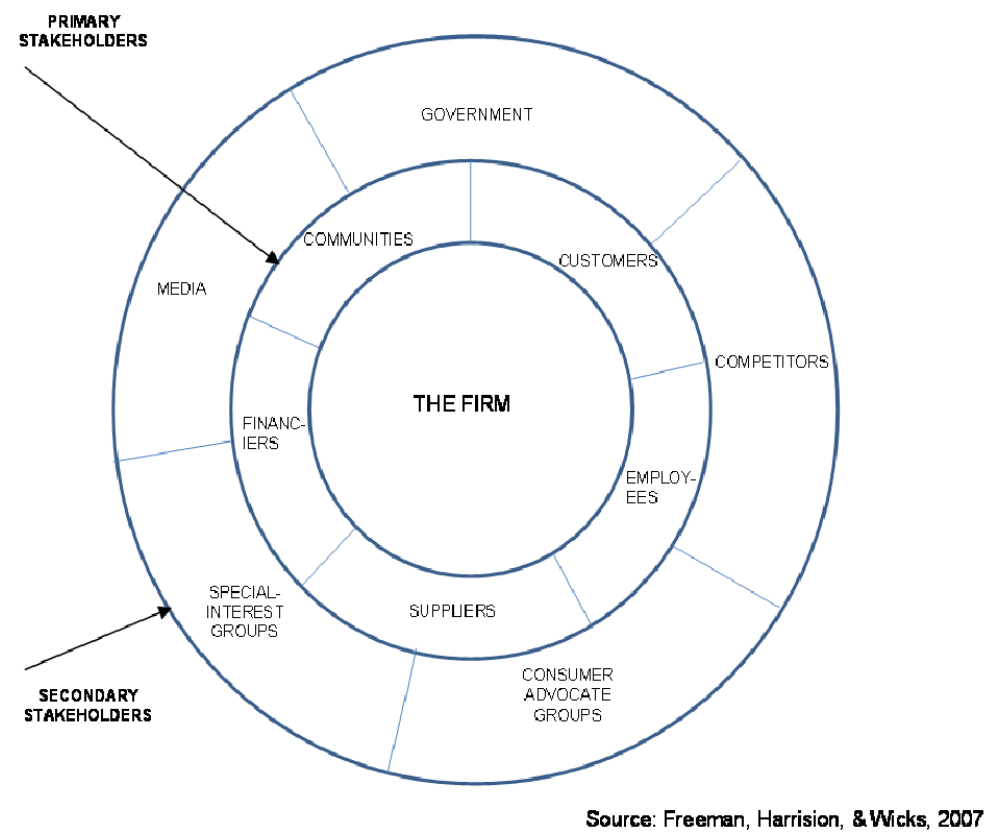

Given their peripheral status in relation to the firm and its primary stakeholders, theory suggests that secondary stakeholders should attract little managerial attention and 
have limited sway over corporate policy (de Bakker \& den Hond, 2008). Indeed, Mitchell and colleagues (1997: 875) liken these groups to "mosquitoes buzzing in the ears of managers: irksome but not dangerous, bothersome, but not warranting more than passing management attention."

Yet we know that mangers not only pay attention to these secondary stakeholders, they often meet their demands - sometimes incurring significant costs in the process. For instance, PepsiCo, Disney, Levi Strauss, and Apple Computer, among others, bowed to pressure from the student-based Free Burma Coalition in the 1990s and divested from Burma (Myanmar) (Spar \& LaMure, 2003); Nike capitulated to the United Students Against Sweatshops and affiliated pressure groups and demanded that foreign suppliers improve working conditions within their factories (Soule, 2009); Starkist conceded to the Earth Island Institute's (EEI) demands that it implement dolphin-safe fishing practices throughout its foreign supply chain (Frooman, 1999); Trader Joe's agreed under pressure from Greenpeace to remove genetically modified products from its shelves (Frooman \& Murrell, 2005); Shell gave in to the demands of Greenpeace that it scuttle plans to dispose of the Brent Spar oil platform at sea and spent $\$ 70$ million to haul the rig to shore for disassembly (Yaziji, 2004); and Aventis capitulated to Friends of the Earth and other environmental NGOs, spending more than $\$ 500$ million to buy back genetically modified StarLink corn from growers (Yaziji \& Doh, 2009). Meanwhile, in 2001, Novartis undertook a series of far-reaching social initiatives, including providing an anti-malaria drug at cost to patients in the developing world before being targeted by NGOs - a move that Spar and LaMure (2003) describe as "preemptive capitulation." 
The success of secondary stakeholders in influencing corporate behavior has stimulated a growing body of theoretical and empirical literature. One stream of research focuses on stakeholder mobilization, and considers which groups are most likely to engage in confrontational tactics such as boycotts (Gardberg \& Newburry, 2010) and shareholder resolutions (Profit \& Spicer, 2006). Another stream focuses on firm response to activism, examining the success of activists in winning concessions from target firms, including the disclosure of information on greenhouse gas emissions (Reid \& Toffel, 2009), improvements in social performance (David, Bloom, \& Hillman, 2007), enhancements to environmental practices (Eesley \& Lenox, 2006; Lenox \& Eesley, 2009), and the addition of healthy items to restaurant menus (Julian, Ofori-Dankwa, \& Justice, 2008).

Yet another research stream examines the stock market's reaction to different stakeholder tactics including boycotts (Pruitt \& Friedman, 1986; Koku et al., 1997), protests (Epstein \& Schnietz, 2002; King \& Soule, 2007), divestiture campaigns (Davidson, Worrell, \& El-Jelly, 1995; Meznar, Nigh, \& Kwok, 1994), proxy resolutions (Reid \& Toffel, 2009; Doh et al., 2010), and a variety of tactics including civil lawsuits (Eesley \& Lenox, 2005). The evidence, by and large, suggests that these tactics typically have only a modest impact on shareholder wealth (Spar \& LaMure, 2003; Vogel, 2005).

A related body of work examines the mechanics by which secondary stakeholder groups exert influence over corporate targets. An important contribution to this literature is Frooman's (1999) model of stakeholder influence. Drawing upon resource dependence theory (Pfeffer \& Salancik, 1978), he argues that stakeholder groups seeking to affect firm behavior typically adopt one of four strategies: Withholding, usage, direct, and 
indirect. Withholding strategies involve restricting the supply of a critical resource to the firm as a means of exerting leverage. Usage strategies involve attaching conditions (i.e., "strings") to the continued supply of a critical resource. Direct influence strategies entail directly manipulating the flow of critical resources. And indirect strategies involve using third parties to influence resource flows to the firm. The choice of a strategy is largely determined by the level of resource dependence (independence) that exists between the stakeholder and the firm (Frooman, 1999).

Frooman and Murrell (2005) offer a modification of this typology. It involves two types of "manipulation strategies" (coercion and compromise), and two types of pathways (direct and indirect). In this model "withholding" represents a coercive manipulation strategy, whereas "usage" a compromise manipulation strategy. Since secondary stakeholder groups usually have few critical resources they can withhold (or threaten to withhold) from the target firm, they typically opt for an indirect influence strategy (Frooman, 1999), which involves appealing to an ally such as consumers or shareholders, who in turn use their leverage with managers to press for change. The EII, as Frooman explains, adopted an indirect strategy in its efforts to convince Starkist to change its tuna procurement policies - it appealed to consumers through a savvy and sophisticated media campaign that included grisly imagery of dolphins being trapped and killed in the netting of fishing trawlers. The ensuing controversy pressured the firm to demand changes in the highly efficient yet inhumane technique its foreign suppliers used to catch tuna.

The models of stakeholder influence articulated by Frooman (1999) and Frooman and Murrell (2005), are broadly consistent with that put forth by Yaziji (2005), who sees 
secondary stakeholders as exerting influence via "critical players" (i.e., primary stakeholders), who in turn use their leverage with firm managers to push for change. We next examine Yaziji's model of social risk, compare it with political risk, and then explore the conceptual fit between these frameworks and the emerging threat of transnational legal activism.

\section{Theory Development}

Social Risk

As previously mentioned, Yaziji (2005) characterizes social risk as threats to firm performance stemming from attacks on the firm's image and reputation by activist groups. At the core of Yaziji's model is the concept of "normative delegitimation." Rooted in the writings of Suchman (1995), Scott (2001), and other neo-institutional theorists, normative delegitimation is the process by which an organization's normative legitimacy is diminished through challenges by outside organizations. These challenges may take the form of boycotts, "brand bashing," shareholder resolutions, and civil lawsuits (Yaziji, 2005).

While some of these actions may impose direct financial costs on the firm, these costs, Yaziji argues, are far less significant than the indirect costs, which may include the loss of trust, confidence, and legitimacy with the critical players. It is concern about damage to these "intangible assets" (Fombrun \& Shanley, 1990; Fombrun, 1996) and relationships which prompts the firm's managers to respond to the activists. Their response may involve initiating delegitimization efforts of their own against the activist groups, issuing threats, extending invitations to negotiate, or adopting policy changes in 
line with the activists' demands. The choice of response is mediated by the activists' success in aligning (or failing to align) with the critical players' interests and institutional norms, the beneficence of the social and economic conditions, and the degree of success of past challenges. Figure 3 provides a conceptual model of social risk based on Yaziji (2005).

Figure 3: A Conceptual Model of Social Risk

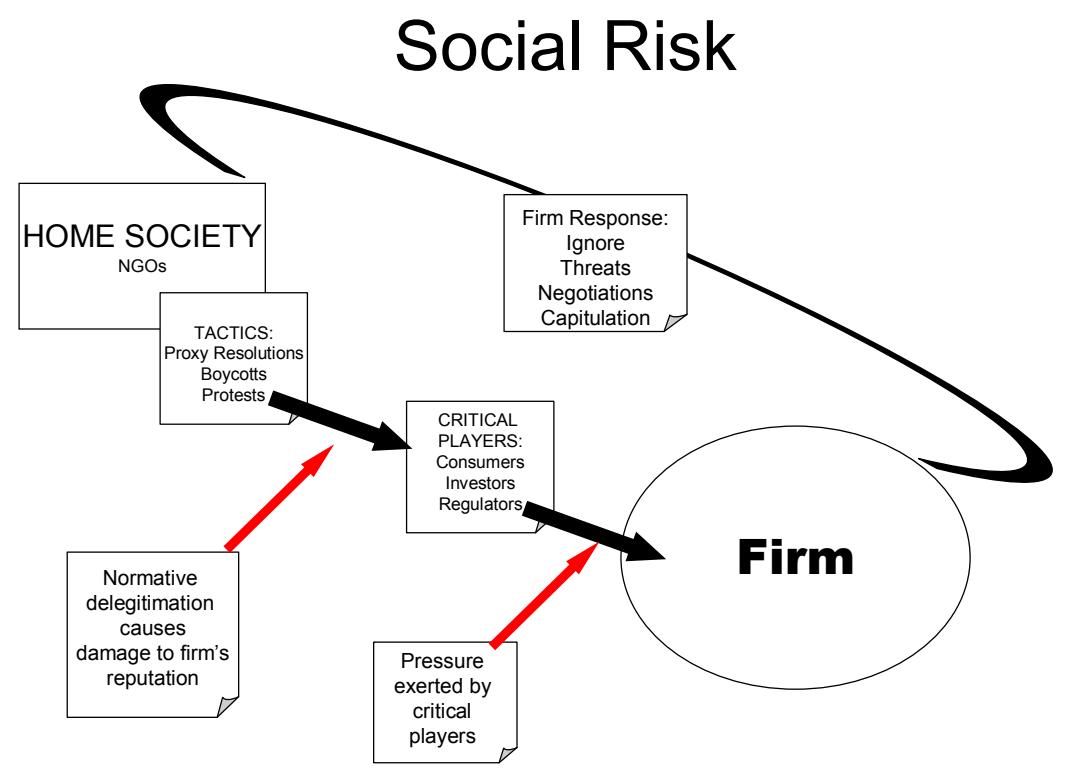

Political Risk

Social risk shares an affinity with political risk in that both streams of research center on firm interactions with non-market players who can affect firm behavior and performance (Yaziji, 2005). Yet social risk is a relatively new concept, whereas political risk is well established in the IB and Strategy literatures (e.g., de la Torre \& Neckar, 
1988; Kobrin, 1982; Simon, 1984; Oetzel, 2005; Wells, 1998). Although many different definitions of political risk have been offered over the years, there is general agreement that it arises from discontinuities in the firm's political environment that are difficult to anticipate and threaten its profitability, performance, operations, and/or strategy (Robock, 1971).

These discontinuities typically stem from the actions of host governments (Wells, 1998), although they can also emerge from actions taken by non-governmental actors in the home, host, or international society (de la Torre \& Neckar, 1988). Examples include protests and strikes initiated by student groups and labor unions, attacks on company property by guerrilla organizations and terrorist groups, and threats against corporate personnel by criminal syndicates (Markwick, 1998). These discontinuities may also emanate from government actions in the home country, such as when the executive or legislative branches impose trade sanctions on "rogue nations," or technology transfer restrictions on particular industries (Simon, 1984). Figure 4 provides a conceptual model of political risk based on Simon (1984). 
Figure 4: A Conceptual Model of the Political Risk

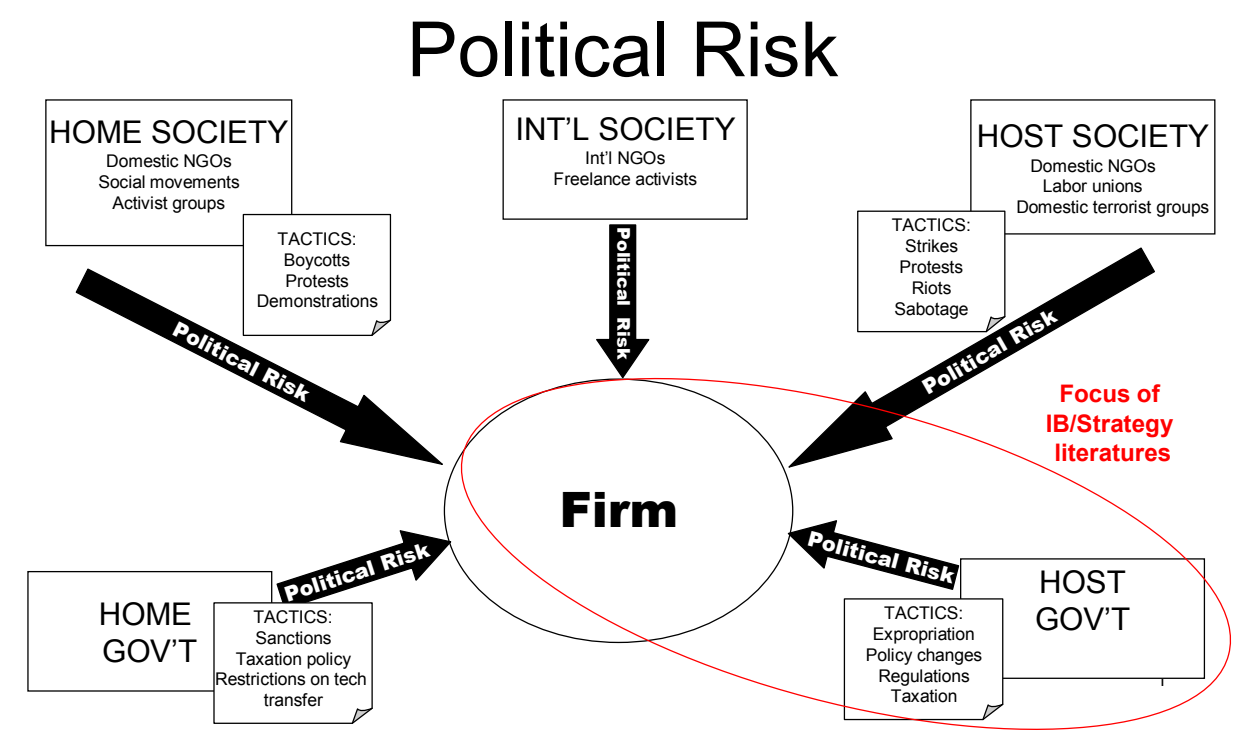

Although political risk can have positive as well as negative consequences for firms - an example of a positive consequence being a sudden change in government that brings a business-friendly regime to power -- the literature focuses on the negative consequences and the managerial strategies that can be adopted to anticipate and mitigate these consequences (Kobrin, 1982). Following Robock (1971), some scholars distinguish between micro (or sub-sovereign) and macro (or sovereign) political risks (Alon, Gurumoorthy, Mitchell, \& Steen, 2006; Alon \& Herbert, 2009; Oetzel, 2005). The former involve threats to select projects and firms, whereas the latter involve threats to many or all projects, firms, and industries in a country. 
Social vs. Political Risk: Toward a Synthesis

As Yaziji (2005) observes, social risk is a close "phenomenal cousin" to political risk. Yet important differences exist. Whereas social risk calls attention to the indirect costs of activist pressures aimed at firms, political risk focuses on the direct costs of such activity, which include the loss of ownership rights (e.g., through expropriation), or, more commonly, operational losses stemming from government interference or discrimination (Kobrin, 1982; Henisz \& Zelner, 2004). Social and political risk also differ over what they identify as the chief source of risk. In the case of political risk, it is typically (though not always) the foreign host government, through its moves to seize assets, impose currency controls, and change laws and regulations in ways that penalize MNEs (Wells, 1998). Social risk, by contrast, is exerted by non-governmental actors through delegitimation campaigns directed at shareholders and public pension funds, customers, the media, regulators, the courts, and the general public (Yaziji \& Doh, 2009). Finally, firms manage these two types of risks in markedly different ways. Political risk is usually managed during the pre-investment phase (Oetzel, 2005) through strategies such as postponement, avoidance, joint ventures, hedging, and insurance (Rivoli \& Salorio, 1996; Wells, 1998), whereas social risk is managed both before and after investments are made, through dialogue, partnerships, philanthropy, and other forms of stakeholder engagement (Yaziji \& Doh, 2009; Oetzel, Getz, \& Ladek, 2007). Whether the emerging threat of transnational legal activism represents a type of political or social risk is the question to which we now turn our attention, following a brief survey of the NGOs that have pioneered this new form of contestation and their legal tool of choice - the ATS. 
The 'Human Rights Revolution,' NGOs, and the Alien Tort Statute

Legal scholar Jeffrey Davis (2008) has referred to the recent efforts to hold MNEs accountable in U.S. federal courts for alleged complicity in human rights abuses in developing countries as a "human rights revolution." This revolution is being driven by a relatively small cadre of U.S.-based NGOs, based in New York and Washington, D.C., using the 200 year-old ATS as their primary legal vehicle. ${ }^{11}$

Originally drafted with an eye toward protecting diplomats and deterring piracy on the high seas, the ATS lay dormant for nearly 200 years until invoked in the late 1970s by a New York-based NGO serving as legal counsel for the family of a Paraguayan citizen who was kidnapped, tortured, and killed by a Paraguayan police inspector in Paraguay who later immigrated to the U.S. While the case was initially dismissed by a U.S. district court on jurisdictional grounds, the U.S. Court of Appeals for the Second Circuit reversed the decision, ruling that torture and extra-judicial killing constitute violations of the "law of nations" and are thus actionable under ATS. The judge awarded the plaintiffs $\$ 10$ million in punitive damages, stimulating new interest in the law as a vehicle for prosecuting crimes against humanity committed on foreign soil (Davis, 2008; Gallagher, 2010).

Subsequent ATS lawsuits targeted prominent political figures including Ferdinand Marcos of the Philippines, and in the mid-1990s, a U.S. federal court ruled that non-state

\footnotetext{
${ }^{11}$ The list of NGOs includes the Center for Constitutional Rights (CCR), Earth Rights International (ERI), International Rights Advocates (IRA), and the International Labor Rights Fund (ILRF). These groups typically draw on the support of public interest attorneys and sometimes work in tandem with private law firms (Drimmer, 2010).
} 
actors, such as Bosnian Serb leader Radovan Karadzic, could be prosecuted for war crimes and other rights abuses. ${ }^{12}$ Shortly thereafter, two NGOs -- the Center for Constitutional Rights (CCR) and Earth Rights International (ERI) -- filed a landmark case on behalf of villagers in Myanmar (Burma) against the U.S. oil and gas company Unocal and its senior executives (Doe v. Unocal). The claims included complicity in forced labor, torture, rape, extra-judicial killings, and other crimes committed by the Burmese military against civilians as part of a $\$ 1.2$ billion natural gas pipeline project in which the company had a minority stake (Holzmeyer, 2009; Schoen, Falchek, \& Hogan, 2005). Unlike previous ATS cases involving corporate defendants, this one survived motions to dismiss, suggesting that U.S. courts viewed the American legal system as the appropriate forum for claims involving serious rights abuses committed by foreign governments and militaries, and the theories of "vicarious corporate liability" upon which these claims rested (Davis, 2008; Shamir, 2004). ${ }^{13}$

Since Doe v. Unocal, plaintiffs have filed dozens of ATS cases against U.S. and foreign-headquartered MNEs over alleged misconduct in some 60 different countries (Drimmer, 2010). ${ }^{14}$ High-profile ATS cases have involved allegations of facilitating

\footnotetext{
${ }^{12}$ The case against Bosnian Serb General Radovan Karadzic (i.e., Kadic v Karadzic) for crimes against humanity was particularly important since Karadzic, who headed an illegitimate government not recognized by the international community, was a private individual rather than a state actor. As Goldhaber (2010) observes, "creative plaintiffs soon concluded that alien tort also applies to non-state actors like corporations that violated the law of nations."

${ }^{13}$ Unocal later won summary judgment in 2000 based on the court's finding that it had neither participated in nor influenced the Burmese military's conduct, however, that ruling was overturned on appeal in 2002, setting the stage for a jury trial. The case was settled prior to trial in 2004 for a reported $\$ 30$ million (Davis, 2008).

${ }^{14}$ Under U.S. law, litigation can only proceed against a corporate defendant where it maintains certain "minimum contacts with the forum." However, U.S. courts have tended to interpret this principle broadly, conferring jurisdiction in cases where the foreign company had no substantial
} 
genocide in Sudan, aiding and abetting atrocities committed by the Apartheid government in South Africa, manufacturing the chemical herbicides used by the U.S. military in the Vietnam War, and conducting non-consensual medical trials on children in Nigeria (Shamir, 2004). Among the MNEs that have been sued under ATS in recent years are Chevron Corp., Royal Dutch/Shell, ExxonMobil, Occidental Petroleum, Talisman Energy, Rio Tinto PLC, Chiquita, Bridgestone, Nestle, Coca-Cola, IBM, Pfizer, Yahoo, and Wal-Mart (Gallagher, 2010).

Although no MNE has yet been found liable in an ATS case that has gone to trial, a number of cases have survived dismissal motions and entered the discovery phase, requiring firms to devote significant resources to legal defense (Kropf, 2010). Some of these cases have lingered in the court system for over a decade, generating negative publicity and tarnishing the reputations of the corporate defendants and their chief officers (Dunst, 2010). Numerous corporate ATS cases have also been settled out of court for large sums, ${ }^{15}$ and two cases involving MNEs have made it to trial. ${ }^{16}$ Some legal

U.S. presence, but was listed on a major U.S. stock exchange or maintained a U.S. investor relations office (Drimmer, 2010).

${ }^{15}$ At least 17 ATS cases involving corporations have been settled over the past 15 years. The list includes the so-called "Nazi gold" lawsuits of the late 1990s, which secured $\$ 1.25$ billion in compensation from Swiss banks for victims of the Holocaust and the case against Unocal in Burma (reportedly between $\$ 30$ and $\$ 60$ million). Other major settlements include those involving U.S. apparel and retail companies for allegations related to sweatshop labor in Saipan (\$20 million), Royal Dutch Shell for alleged human rights violations in the Niger Delta (\$15.5 million), and Yahoo! Inc. for divulging private information on political dissidents to the Chinese government (undisclosed amount) (Goldhaber, 2010).

${ }^{16}$ One of these cases (Bowoto v. Chevron) alleged that Chevron was complicit in the Nigerian military's violent crackdown against unarmed protesters at one of the company's offshore oil platforms. The other case (Romero v. Drummond Co.) was based on accusations that the Drummond Company conspired with Colombian paramilitary organizations to murder union leaders at one of its coal mines (Kropf, 2010). 
analysts believe it is just a matter of time before a defendant is found liable, which would presumably incentivize new cases (Drimmer, 2010).

\section{NGOs as Transnational Advocacy Networks}

While the human rights NGOs that have initiated much of the recent ATS litigation against MNEs typically have small staffs and modest budgets, they extend their reach and maximize their impact by operating as "transnational advocacy networks" (Risse et al., 1999), drawing upon the support of individuals and organizations throughout the world. Such networks are characterized by "shared values and by dense exchanges of information and services" (Sikkink, 1993). Key constituents of transnational human rights networks include NGOs and labor unions at home and abroad, grassroots community activists, academics, individual public interest attorneys, and even attorneys with large corporate law firms that offer pro-bono services (Davis, 2008).

ERI is a good example of an organization that functions as a transnational advocacy network. One of the two NGOs that served as legal counsel to the plaintiffs in the Doe v. Unocal case, ERI maintains a permanent staff of fewer than two dozen attorneys and administrators in Washington, D.C., with an annual budget of less than $\$ 2$ million. Yet its global network of alliances and partnerships is extensive. The network includes an overseas branch in Chaing Mai, Thailand, which oversees the organization's activities in Burma and Southeast Asia, partnerships with leading U.S. and European human rights NGOs, including Human Rights Watch, Human Rights First, Global Witness, and Amnesty International through the International Corporate Accountability Roundtable (ICAR), and relationships with an array of NGOs and grassroots groups 
throughout the developing world. Meanwhile, ERI maintains tight links with foreign attorneys through initiatives like the Mekong Legal Advocacy Institute, a forum for lawyers in South East Asia to network and "develop new legal and advocacy strategies, and take effective coordinated actions to protect the environment and human rights" (earthrights.org).

The importance of this extended network to ERI's success was recently underscored by the organization's executive director: "Making sure that local NGOs are involved is of the utmost importance, because lawyers in D.C. aren't going to know how to go into the pipeline region of Burma and gather evidence that the government doesn't want gathered and not put themselves and others in danger. In many of these (ATS) cases, just for pure logistics, you have to have local people who know what a human rights abuse is and know how to document it in a way that's reliable" (Davis, 2008: 83).

ERI also participates in organizations such as Publish What You Pay, a global civil society coalition that claims to help citizens of developing countries hold their governments accountable for the management of revenues derived from natural resource projects, Save the Mekong, ESCR-Net, Network for Human Rights Documentation Burma, and The True Cost of Chevron, an initiative comprising some 40 NGOs from 20 countries or U.S. states, including Amazon Watch, Global Exchange, Greenpeace, the Rainforest Action Network, and Public Citizen. The initiative describes itself as "a unique collaboration of indigenous, native, and First Nation communities and their allies resisting the destructive human rights and environmental policies of Chevron and the entire oil industry" (earthrights.org). 


\section{Extra-Legal Activism}

In addition to their legal advocacy efforts, human rights NGOs often engage in extra-legal activism, purportedly to pressure firms to settle these lawsuits on terms favorable to the plaintiffs and gain leverage in the legal proceedings. As Drimmer (2010) observes, these out-of-court tactics cluster into four categories: media-related activities, community organizing activities, investment-related activities, and political advocacy activities.

Media-related activities include creating websites to showcase news about the case and mobilize support and donations, authoring opinion-editorials in newspapers, granting media interviews, staging press conferences to coincide with key events such as the filing of new litigation, and filming mini-documentaries (and sometimes full-length films) about the cases; community organizing activities involve organizing protests and boycotts of the goods and services of target firms; investment-related activities include introducing proxy resolutions at shareholder meetings, pressuring institutional investors to divest from the target company, and contacting the Securities and Exchange Commission to initiate investigations; and political advocacy activities include testifying at Congressional hearings (Drimmer, 2010).

ERI, which has filed ATS cases against Unocal, Occidental Petroleum, Chiquita, Chevron, Union Carbide, and Shell in recent years, engages in a wide variety of extralegal tactics. In the context of its campaign against Unocal for its investment in Burma, ERI has published reports critical of the company's activities, written letters to Chevron senior executives accusing the company of supporting repression, and published antiChevron opinion-editorials in international newspapers. It also has organized events to 
promote "Total Denial," a documentary by an independent filmmaker about the Unocal case. The anti-Chevron campaign continues to this day, notwithstanding the fact that the legal case was settled in 2004 (earthrights.org).

International Rights Advocates (IRA) is another U.S.-based human rights NGO that engages in extensive extra-legal tactics in support of its ATS litigation. In concert with an ATS lawsuit it filed against Coca-Cola for alleged complicity in repression against union leaders at a Colombian bottling facility (Sinaltrainal v. The Coca-Cola Company), IRA launched the "Killer Coke" campaign, a multi-pronged grassroots effort designed to "hold The Coca-Cola Company, its bottlers and subsidiaries accountable and to end the gruesome cycle of violence and collaboration with paramilitary thugs, particularly in Colombia" (killercoke.org). The site contains visceral imagery including mock Coca-Cola ads with captions such as "Murder: It's the Real Thing," and exhorts activists to demonstrate, leaflet, and write letters to the offices of Coke's Board of Directors (killercoke.org). While the legal effort against Coca-Cola has yet to bear fruit, the activist campaign has produced results: In 2006 TIAA-CREF sold 1.2 million shares of Coca-Cola stock, worth over $\$ 50$ million, from its Social Choice Fund. The move followed the decision of KLD Analytics to remove the firm from its Broad Market Social Index (BMSI) list of socially responsible firms, in part because of allegations of human rights violations in Colombia (Mankowski, 2006).

\section{Discussion}


Transnational Legal Risk: A New and Unique Threat to MNEs?

The foregoing analysis suggests that human rights NGOs are operating on two tracks simultaneously - the legal track, in which they seek to obtain favorable dispensations in the courtroom or lucrative financial settlements, and the activist track, in which they seek to harm the target firm's image and reputation as a means of gaining leverage over the firm and winning concessions. From the perspective of the target firm, the first of these tracks resembles political risk in the sense that it exposes the firm to direct financial costs in the form of legal fees, court costs, and public relations expenditures, while diverting managerial time and attention away from running the organization. Such maneuvers also expose the firm to the possibility of substantial out-ofcourt settlements and billion-dollar judgments.

The second track, however, resembles social risk in the sense that it raises the prospect of indirect financial harm to the firm through damage to its image, reputation, and ultimately the loss of legitimacy. The potential costs of such reputational damage include the loss of customers, clients, employees, investors, and suppliers, as firms distance themselves from the target and withhold critical resources. An additional cost to the firm is the heightened possibility of regulatory action. Given that neither the social or political risk frameworks adequately capture the essence of this new and increasingly salient threat to MNE operations, we believe it merits a new label: "transnational legal risk." We define this as the risk to a firm's performance and reputation caused by transnational networks of human rights activists employing legal and/or extra-legal tactics in the home country to win concessions. Table 1 compares key aspects of transnational risk with political and social risk. 
Table 1: Political, Social and Transnational Legal Risk - Key Aspects

\begin{tabular}{|c|c|c|c|}
\hline & Political risk & Social risk & Transnational legal risk \\
\hline Focus & $\begin{array}{l}\text { government interference } \\
\text { - primarily in the host } \\
\text { country }\end{array}$ & $\begin{array}{l}\text { NGO and social } \\
\text { movement activism - } \\
\text { primarily in the home } \\
\text { country }\end{array}$ & $\begin{array}{l}\text { NGO and social movement } \\
\text { activism - in both the host } \\
\text { and home countries }\end{array}$ \\
\hline Tactics & $\begin{array}{l}\text {-expropriation } \\
\text {-f/x controls } \\
\text {-taxation } \\
\text {-restrictions on profit } \\
\text { remittances } \\
\text {-local content } \\
\text { requirements } \\
\text {-export performance } \\
\text { requirements }\end{array}$ & $\begin{array}{l}\text {-shareholder resolutions } \\
\text {-boycotts } \\
\text {-protests } \\
\text {-letter-writing campaigns } \\
\text {-civil litigation }\end{array}$ & $\begin{array}{l}\text {-civil litigation } \\
\text { (extraterritorial) } \\
\text {-shareholder resolutions } \\
\text {-boycotts } \\
\text {-protests } \\
\text {-letter-writing campaigns }\end{array}$ \\
\hline Costs & direct & $\begin{array}{l}\text { indirect (damage to } \\
\text { image, reputation, and } \\
\text { legitimacy) }\end{array}$ & $\begin{array}{l}\text { direct (legal, pr expenses) } \\
\text { and indirect (damage to } \\
\text { image, reputation, } \\
\text { legitimacy) }\end{array}$ \\
\hline $\begin{array}{l}\text { Nature of } \\
\text { influence }\end{array}$ & direct (govt to MNE) & $\begin{array}{l}\text { indirect (NGO to MNE } \\
\text { via "critical players") }\end{array}$ & direct and indirect \\
\hline Risk management & $\begin{array}{l}\text {-avoidance } \\
\text {-postponement } \\
\text {-joint ventures } \\
\text {-lobbying } \\
\text {-insurance } \\
\text {-hedging } \\
\text {-diversification }\end{array}$ & $\begin{array}{l}\text {-avoidance } \\
\text {-cross-sectoral } \\
\text { partnerships } \\
\text {-CSR initiatives } \\
\text {-community relations }\end{array}$ & $\begin{array}{l}\text {-avoidance } \\
\text {-cross-sectoral partnerships } \\
\text {-CSR initiatives } \\
\text {-community relations }\end{array}$ \\
\hline Theme & $\begin{array}{l}\text { building barriers around } \\
\text { the firm (insulation) }\end{array}$ & $\begin{array}{l}\text { breaking down barriers } \\
\text { (engagement) }\end{array}$ & $\begin{array}{l}\text { breaking down barriers } \\
\text { (engagement) }\end{array}$ \\
\hline
\end{tabular}


VI. Conclusion

As de Bakker \& den Hond (2008) recently observed, despite more than 25 years of research on stakeholder theory since Freeman's seminal (1984) contribution, scholars know relatively little about the mechanisms by which external agents influence organizational behavior. This research helps fill this gap by examining how an increasingly influential group of secondary stakeholders - human rights activists - are using civil litigation and extra-legal tactics to press for concessions from MNEs. Given the growing importance of civil litigation to the efforts of NGOs and the relative dearth of scholarly analysis on this topic in the management literature in comparison to other anti-corporate tactics such as boycotts, protests, and proxy resolutions, this research fills an important void.

In a broader sense, this research contributes to the scholarly effort to understand how a range of relatively resource-poor and powerless groups including NGOs (Doh \& Teegen, 2003; Yaziji \& Doh, 2009), social movements (King \& Soule, 2007; King, 2008; Soule, 2009), and transnational advocacy networks (Riesse et al., 1999) are seeking to change corporate policies and practices, promote institutional change, and press for new and binding global norms governing the conduct of international business. Moreover, by offering insights into the ways in which MNEs conceptualize and manage threats to their tangible and intangible assets, this research contributes to the literatures on political and social risk and the non-market strategies of firms (Bonardi \& Keim, 2005; Bonardi, Hillman, \& Keim, 2005). This research also draws attention to the social and moral ramifications of MNE behavior in the developing world - an issue that has been 
identified as one of high importance for IB researchers (Ricart, Enright, and Ghemawat, 2004).

Beyond its theoretical contributions, this research has relevance for practice. As Frooman (1999) observes, knowing how stakeholders may try to influence a firm is critical knowledge for any manager since strategic planning and action presupposes some understanding of how organizations in their environment will act and react. By offering insights into the different tactics that activist stakeholder groups employ -- both inside and outside of the courtroom -- this research contributes to that endeavor.

An important conclusion of this research is that firms targeted with human rightsrelated litigation need to take into account both the direct and the indirect costs of these lawsuits - the latter of which include image damage, loss of brand equity, and diminished social legitimacy. Moreover, they need to realize that such challenges are more than a legal fight - they are a battle for the hearts and minds of stakeholders (Garcia \& Ewing, 2008). Or, stated differently, they are "public relations and political wars" with the courtroom battle being just one theater in a wider war (Garcia \& Ewing, 2008). As such, MNEs should approach these challenges in a very different way than they would other types of litigation. Elements of an effective counter-strategy, as Garcia and Ewing (2008) observe, include acting quickly to disclose all relevant information about the allegations "before the media frenzy begins," crafting a simple message that can be understood by a variety of audiences (e.g., legal, public, and policy), communicating it forcefully, and mobilizing allies and using them to "tell the story" - in a word, many of the same extralegal techniques that the claimants have used so effectively against corporations. 
It has been suggested that firms facing class-action lawsuits brought by private (non-corporate) plaintiffs ought to litigate these cases, while settling those brought by other firms, since the latter have a higher probability of success and are viewed by the markets as more threatening (Koku, 2006). And while it is true that no private plaintiff has yet prevailed in a corporate ATS case that has gone to trial (Drimmer, 2010), such advice ignores the exceptionally high reputational risks associated with ATS claims, which, after all, involve allegations of complicity in genocide, murder, torture, rape, and other heinous acts. Moreover, the tendency for these cases to linger in the court system for years, owing to lengthy motion practice, discovery, appeals, and frequent reversals of lower court rulings by appellate courts, only magnifies the potential impact. The case against Royal Dutch Shell for its alleged complicity in the 1995 execution of Ogoni human rights activist Ken Saro-Wiwa by the Nigerian military is a case in point. That litigation, which attracted an international outcry and became a cause célèbre amongst activists, dragged on for 13 years, blighting the company's otherwise positive reputation on social issues. ${ }^{17}$ The parties ultimately agreed to a $\$ 15.5$ million settlement on the eve of the trial in 2009, although in many respects the damage had already been done (Dunst, 2009). In this case, and many others, the defendant clearly would have been better off opting for mediation or a settlement earlier in the game.

\footnotetext{
${ }^{17}$ In 2009 activists groups, including PLATFORM, Oil Change International, and Friends of the Earth launched the "Shell Guilty" campaign, which included the release of reports critical of the firm's activities in the Niger Delta, protests, and international press conferences. These and other groups also initiated a media campaign, "Remember Ken Saro-Wiwa? Shell Would Rather You Didn't," that included the placement of full page anti-Shell advertisements in major UK newspapers (anitaroddick.com, 2010).
} 
While this research does not directly address the question of what strategies MNEs can take to reduce their vulnerability to ATS litigation, some implications can be drawn. First, companies can enhance their due diligence, by adopting codes of conduct, carefully screening potential business partners, and hiring third parties to monitor the compliance of these partners with company codes (Drimmer \& Millerwise Dyck, 2009). Beyond these steps, MNEs can adopt one of three strategies, which we label avoidance, resistance, and engagement.

Avoidance involves steering clear of countries with repressive governments, weak institutions, and chronic human and labor rights violations. And indeed, anecdotal evidence suggests that some companies - particularly small and medium-size firms -- are thinking twice about investing in certain high risk countries due to concerns about legal liability. ${ }^{18}$ But given the importance of emerging markets to the business strategies of MNEs (Khanna \& Palepu, 2010), and the fact that ATS cases have been brought against firms operating in over 60 countries including some of the world's largest and fastestgrowing markets (e.g., China, India, Indonesia, and South Africa), avoidance would seem to be a questionable strategy.

Resistance involves undertaking efforts to oppose the application of ATS to corporations, while attempting to delegitimize or co-opt the groups behind these lawsuits (Shamir, 2004). To this end, MNEs have conducted a vigorous lobbying effort in Washington aimed at convincing policymakers to repeal or amend the statute. The campaign has been spearheaded by business groups such as USA*Engage, the National

\footnotetext{
${ }^{18}$ Davis (2008: 238) quotes an interview with a senior U.S. State Department lawyer who remarked: "In a certain number of instances small and medium size businesses their risk advisors are telling them not to go in conflictive situations simply because.... of the legal fees of defending (against ATS lawsuits)."
} 
Foreign Trade Council, the U.S. Chamber of Commerce, the U.S. Council for International Business, and the Organization for International Investment (Davis, 2008). These groups have also filed friend of the court (amicus) briefs with district courts urging them to drop these cases and petitioned the U.S. Supreme Court to settle the matter of "corporate liability" once and for all. Their efforts appeared to bear fruit in 2004 when the high court took up an ATS-related case (Sosa v. Alvarez Machain), but the court's ruling that the door should remain open to corporate ATS lawsuits "subject to vigilant door-keeping" was hardly the result the business community had sought (Shamir, 2004). Meanwhile, a July 2011 ruling by a federal appeals court overturning a lower court's decision in favor of Exxon Mobil in a 2001 ATS case brought by Indonesian plaintiffs over claims of murder, torture, and other atrocities has raised speculation that the Supreme Court will again address this matter, yet how the justices will rule is anyone's guess (Stempel, 2011b).

Engagement, in our view, is the most promising strategic approach to ATS vulnerability. It involves pursuing dialogue with activists (Hart \& Sharma, 2004; Yaziji, 2004), seeking mediation (Rees, 2010), and embracing corporate citizenship initiatives (Gardberg \& Fombrun, 2006), including voluntary codes of conduct, private certification schemes, and philanthropic support for community education, health, and environmental projects. While there are obvious financial costs to an engagement strategy and no evidence that such a strategy reduces the risk of being targeted by activists, there are huge potential benefits. These include enhanced trust, confidence, and goodwill from local communities, greater legitimacy, and a more robust "social license" to operate (Gunningham, Kagan, \& Thornton, 2004). Firms adopting an engagement strategy in 
developing countries may realize other benefits too, including better employee recruitment and retention, increased sales, reduced insurance risk premiums, and improved relations with host governments and other stakeholders, thereby leading to a sustainable, long-term competitive advantage (Oetzel et al., 2007).

An example of a firm that has adopted an engagement strategy is France's La Farge Group, the world's second-largest cement-maker. Among the many different countries in which Lafarge operates is Indonesia, where it has a plant in the city of Banda Aceh, located in the restive northern province of Aceh, Sumatra. Aware of the "liability of foreigness" associated with being a Western company in the world's largest Muslim nation, Lafarge has actively looked for ways to enhance its social legitimacy. It perceived an opportunity following the December 2004 Southeast Asian tsunami, which devastated the area, killing nearly one-third of its local workers and contractors (Lafarge, 2005). In much the same way that Wal-Mart responded to Hurricane Katrina, Lafarge quickly mobilized workers and resources to assist local community groups with relief and reconstruction. In the months that followed the disaster it built over 300 houses, set up clinics, restaurants, and schools, purchased school supplies, and even renovated mosques (Lafarge, 2005). The result, as Kapstein (2006) observes, is that "Lafarge is widely appreciated in Banda Aceh, and harming its plant or people in any way would not make good political sense for those who wish to make a statement." Similarly, we might presume that the idea of filing an ATS lawsuit against the company would gain little traction within the local community - notwithstanding the fact that ATS lawsuits have been filed against other Western MNEs operating in Indonesia, including Exxon Mobil and Freeport McMoran. 
Finally, this research has relevance for public policy. The sharp rise in ATS lawsuits against MNEs in recent years and the size of the damages sought has raised concerns amongst policymakers that foreign direct investment -- an important engine of global economic growth -- could be curtailed (Fergenson \& Merrigan, 2007). Indeed, Hufbauer (2009) warns that the growing tide of ATS litigation could "chill investment in non-OECD countries," slowing economic growth and increasing human suffering in countries that account for over 5 billion people and half the world economy. Moreover, Hufbauer and Mitrokostas (2004) estimate that $\$ 55$ billion in U.S. foreign direct investment (FDI) could be deterred by ATS lawsuits, jeopardizing some $\$ 10$ billion in U.S. exports and 80,000 manufacturing jobs. Concerns over ATS liability could also discourage foreign-based MNEs from investing in the U.S., costing thousands of additional American jobs (Hufbauer \& Mitrokostas, 2004).

Business and political leaders also warn that the exit of Western MNEs from emerging nations in Africa and Southeast Asia owing to legal concerns could diminish Western strategic influence in countries seen as important partners in the struggle against international terrorism, while opening the door to investment by state-owned firms from emerging nations that are less beholden to pressures from civil society and less committed to social responsibility (Schrage, 2003). Indeed, when Talisman Energy divested from an oil pipeline project in the Sudan in 2003 amidst intense stakeholder pressure, India's state-owned oil company ONGC Videsh Limited purchased its assets. The project continues to this day, but without the community development projects and transparency initiatives that Talisman claims it had implemented (Manhas, 2007). 
This research suggests that the concerns of business and political leaders are legitimate. But so too are the concerns of activist groups that have called attention to the growing disparity in economic power between MNEs and their developing country hosts, and the historic ability of these firms to influence (and sometimes subvert) local laws and regulations while evading responsibility for grievous crimes committed on their behalf or in their interests by sovereign governments and their security forces. In the absence of a new and binding global framework that spells out the specific social responsibilities and moral obligations of MNEs operating in developing countries, private efforts by transnational activist networks to hold them accountable for overseas rights abuses are bound to continue, with major ramifications for firms that do international business, and the governments and citizens of the nations where they do it. 
Essay II: Secondary Stakeholder Legal Action and Stock Market Performance: An Event Study of Alien Tort Statue Litigation Filed Against Multinational Enterprises: 1993-2010

VII. Abstract and Introduction

Secondary stakeholder groups have filed dozens of civil lawsuits in U.S. federal courts against multinational enterprises in recent years over alleged human rights abuses, labor violations, and environmental crimes in developing countries. Multinational business leaders complain that these lawsuits add to their cost of doing business and hamper their global competiveness. Anecdotal evidence suggests that their concerns may be justified. But does the empirical evidence bear this out? To answer this question we conducted an event study of lawsuits filed against multinational enterprises between 1993 and 2010 under the U.S. Alien Tort Statute, a law that gives U.S. federal courts extraterritorial jurisdiction for cases involving allegations of serious offenses committed against foreign citizens. Our analysis shows that target firms experienced a significant decline in share price upon filing and that both industry and nature of the lawsuit had a significant and negative relationship to shareholder wealth. We offer conclusions and implications for practice.

The rise of anti-corporate activism represents a challenge to international management theory and practice. Although a rich stream of international business (IB) and management literature exists on non-market threats to the multinational firm (Chambers, Wernick, Zdanowicz, \& Von Glinow, 2010; Grosse, 2005; Henisz, Mansfield, \& Von Glinow, 2010), this literature tends to focus on political risks to 
investors emanating from the acts of host governments (Kobrin, 1979; de la Torre \& Neckar, 1988), and the opportunistic policy decisions these sovereign entities often take (Henisz \& Zelner, 2010). For many multinational firms today, however, the biggest nonmarket threat they face comes not from governments abroad, but from individuals and non-governmental organizations (NGOs) domiciled in the home country, or from networks of activists spanning multiple countries (Keck \& Sikkink, 1998; Tarrow, 2005; Doh \& Teegen, 2003).

By launching boycotts and protests and filing shareholder resolutions and civil lawsuits, these activist groups damage corporate reputations, tarnish brands, and undermine the firm's legitimacy in the eyes of the public (Soule, 2009; Spar \& La Mure, 2003; Yazjij, 2005). Companies stigmatized as poor corporate citizens may also experience difficulty recruiting and retaining employees, customers, and suppliers, and raising investment capital (David et al., 2007; Turban \& Greening, 1997). Given the stakes, it is no surprise that multinational enterprises (MNEs) have responded to the threat of being "named and shamed" by devoting increasing attention and resources to social risk identification (Yaziji \& Doh, 2009), stakeholder management (Hillman \& Keim, 2001), and corporate citizenship initiatives (Gardberg \& Fombrun, 2006). ${ }^{19}$

Management and organization researchers seeking to understand the interplay between activist groups and corporations have recently employed stakeholder theory (Freeman, 1984) as a theoretical lens (Laplume, Sonpar, \& Litz, 2008). Stakeholder

\footnotetext{
${ }^{19}$ Corporate citizenship refers to the range of socioeconomic activities that companies undertake to fulfill perceived duties as members of society. Examples include charitable giving, pro bono activities, volunteerism, and support for community educational, health, and environmental programs (Gardberg \& Fombrun, 2006).
} 
theory accords social activists the status of "secondary stakeholders," which, unlike primary stakeholders (e.g., shareholders, employees, suppliers, and creditors), are not vital to organizational survival (Clarkson, 1995). As such, these groups should attract little managerial attention (Mitchell et al., 1997). Yet the empirical literature suggests that managers often do pay careful attention to the demands of these secondary stakeholders and sometimes make significant concessions (Eesley \& Lenox, 2006; King, 2008). This reality has stimulated new research that examines when and why these groups mobilize (Rowley \& Moldoveneau, 2003; den Hond \& de Bakker, 2007), how they select their targets (Rehbein et al., 2004; Hendry, 2006; Lenox \& Eesley, 2009), the different influence strategies they employ (Frooman, 1999; Frooman \& Murrell, 2005), and the factors that influence firm response (Spar \& LaMure, 2002; Reid \& Toffel, 2009). Researchers have also analyzed the shareholder wealth implications of common stakeholder tactics such as boycotts (Pruitt \& Friedman, 1986; King, 2008), protests (Epstein \& Schnietz, 2002; King \& Soule, 2007), letter-writing campaigns (Smith \& Cooper-Martin, 1997), divestitures (Davidson, Worrell, \& El-Jelly, 1995), and proxy resolutions (Reid \& Toffel, 2009; Doh et al., 2010).

What is surprising, however, is that scholars have devoted scarce attention to empirically measuring the stock market's reaction to the filing of civil lawsuits by stakeholder groups. This is surprising because stakeholder groups are increasingly employing civil litigation as a central pillar of their anti-corporate campaigns (Kurlantzick, 2004). Moreover, one of the few studies to examine corporate response to a variety of stakeholder tactics including protests and boycotts found that civil suits were more likely to elicit concessions than any other tactic (Eesley \& Lenox, 2006). 
Given that corporate share price is a widely accepted benchmark for assessing managerial performance (Lambert \& Larker, 1987), if the filing of civil lawsuits is associated with a loss of shareholder wealth, then managers might have an incentive to engage with stakeholder groups and settle these complaints before they result in litigation (e.g. through mediation), or undertake measures that would make their firms and senior executives less of a target in the first place. Such measures might include adopting voluntary codes of conduct, participating in private certification programs (Vogel, 2008), or engaging in multi-sectoral partnerships (Dahan et al., 2010). Many MNEs have established such alliances in recent years and claim to be benefiting from them (Kourala \& Laasonen, 2010). Conversely, if there is no relationship between the filing of these lawsuits and corporate share price, firms might choose to ignore them and let the legal process run its course - in much the same way that managers of boycotted firms have often paid them little attention. ${ }^{20}$ Either way, the question of whether and how secondary stakeholder-initiated litigation affects corporate share price has great relevance for multinational strategy.

\section{The U.S. Legal Environment and Transnational Tort Litigation}

The U.S. has been dubbed the "litigious society" (Baye, Kovenock, \& de Vries, 2005). Indeed, trial attorneys in America generate almost $\$ 50$ billion per year in revenue through tort litigation - more than the annual revenues of Microsoft and Intel, and double the global sales of Coca-Cola (Center for Legal Policy, 2010). In recent years the

\footnotetext{
${ }^{20}$ Procter \& Gamble's chairman, for example, refused to acquiesce to boycotters' demands in the early 1990s that his company cease from purchasing coffee beans from El Salvador -- the revenues from which were claimed to be financing right-wing death squads -- because he knew the action would have little or no financial impact (Koku, Akhigbe, \& Springer, 1997).
} 
proliferation of class-action lawsuits, which permit one or more parties to sue (or be sued) on behalf of all those who are similarly situated, has further increased the legal burden companies face, with multi-billion dollar settlements occurring in cases involving tobacco, silicone breast implants, the Dalkon Shield intrauterine device, and the diet supplement Fen-Phen, while others related to fast food, lead paint, firearms, Chinese dry wall, and asbestos may be on the horizon.

Although many different types of civil litigation are on the rise, the growth of transnational tort litigation has been particularly noteworthy (Drimmer, 2010). These cases involve allegations of personal or environmental harms stemming from corporate misconduct overseas. While some transnational tort cases deal with fairly mundane issues such as personal injury claims and allegations of negligent business practices, a growing number involve allegations of complicity in serious overseas human and labor rights abuses and environmental crimes. The primary vehicle for these lawsuits in the U.S. is the ATS, a controversial law that allows foreign citizens to sue government officials, private individuals, and corporations in U.S. federal courts for particular violations of international law or a treaty of the U.S. (Davis, 2008).

Originally drafted with an eye toward protecting diplomats and deterring piracy on the high seas, the ATS lay dormant for nearly 200 years until invoked in the late 1970s by a New York-based non-governmental organization (NGO) serving as legal counsel for the family of a Paraguayan citizen who was kidnapped, tortured, and killed by a Paraguayan police inspector in Paraguay who later immigrated to the U.S. (Kobrin, 2005). While the case was initially dismissed by a U.S. district court on jurisdictional grounds, the U.S. Court of Appeals for the Second Circuit reversed the decision, ruling 
that torture and extra-judicial killing constitute violations of the "law of nations" and are thus actionable under ATS. The judge awarded the plaintiffs $\$ 10$ million in punitive damages, stimulating new interest in the law as a vehicle for prosecuting crimes against humanity committed on foreign soil (Davis, 2008; Gallagher, 2010).

Subsequent ATS lawsuits targeted prominent political figures including former Philippines dictator Ferdinand Marcos, and in the mid-1990s, a U.S. federal court ruled that non-state actors, such as Bosnian Serb leader Radovan Karadzic, could be prosecuted for war crimes and other rights abuses. ${ }^{21}$ Shortly thereafter, two NGOs -- the Center for Constitutional Rights and Earth Rights International -- filed a landmark case on behalf of villagers in Myanmar (Burma) against the U.S. oil and gas company Unocal and its senior executives (Doe v. Unocal). The claims included complicity in forced labor, torture, rape, extra-judicial killings, and other crimes committed by the Burmese military against civilians as part of a $\$ 1.2$ billion natural gas pipeline project in which the company had a minority stake (Holzmeyer, 2009; Schoen, Falchek, \& Hogan, 2005). Unlike previous ATS cases involving corporate defendants, this one survived motions to dismiss, suggesting that U.S. courts viewed the American legal system as the appropriate forum for adjudicating claims of serious rights abuses committed by foreign governments and militaries, and the theories of "vicarious corporate liability" upon which these claims rested (Davis, 2008; Shamir, 2004). ${ }^{22}$

\footnotetext{
${ }^{21}$ The case against Bosnian Serb General Radovan Karadzic (i.e., Kadic v Karadzic) for crimes against humanity was particularly important since Karadzic, who headed an illegitimate government not recognized by the international community, was a private individual rather than a state actor. As Goldhaber (2010) observes, "creative plaintiffs soon concluded that alien tort also applies to non-state actors like corporations that violated the law of nations."

${ }^{22}$ Unocal later won summary judgment in 2000 based on the court's finding that it had neither participated in nor influenced the Burmese military's conduct, however, that ruling was
} 
Since Doe v. Unocal, plaintiffs have filed dozens of ATS cases against U.S. and foreign-headquartered MNEs over alleged misconduct in some 60 different countries (Drimmer, 2010). ${ }^{23}$ High-profile ATS cases have involved allegations of facilitating genocide in Sudan, aiding and abetting atrocities committed by the Apartheid government in South Africa, manufacturing the chemical herbicides used by the U.S. military in the Vietnam War, and conducting non-consensual medical trials on children in Nigeria (Shamir, 2010). Among the MNEs that have been sued under ATS in recent years are Chevron Corp., Royal Dutch/Shell, ExxonMobil, Occidental Petroleum, Talisman Energy, Rio Tinto PLC, Chiquita, Bridgestone, Nestle, Coca-Cola, IBM, Pfizer, Yahoo, and Wal-Mart (Gallagher, 2010).

Although no multinational corporate defendant has yet been found liable in an ATS case that has gone to trial, a number of cases have survived dismissal motions and entered the discovery phase, requiring firms to devote significant resources to legal defense (Williams \& Conley, 2007; Kropf, 2010). Some of these cases have lingered in the court system for over a decade, generating negative publicity and tarnishing the reputations of the corporate defendants and their chief officers (Dunst, 2010). Numerous corporate ATS cases have also been settled out of court for large sums, ${ }^{24}$ and two cases

overturned on appeal in 2002, setting the stage for a jury trial. The case was settled prior to trial in 2004 for a reported $\$ 30$ million (Davis, 2008).

${ }^{23}$ Under U.S. law, litigation can only proceed against a corporate defendant where it maintains certain "minimum contacts with the forum." However, U.S. courts have tended to interpret this principle broadly, conferring jurisdiction in cases where the foreign company had no substantial U.S. presence, but was listed on a major U.S. stock exchange or maintained a U.S. investor relations office (Drimmer, 2010).

${ }^{24}$ At least 17 ATS cases involving corporations have been settled over the past 15 years. The list includes the so-called "Nazi gold" lawsuits of the late 1990s, which secured $\$ 1.25$ billion in 
involving MNEs have made it to trial. ${ }^{25}$ Some legal analysts believe it is just a matter of time before a defendant is found liable, which would presumably incentivize new cases (Drimmer, 2010).

The U.S. business community has been an outspoken critic of ATS and has mobilized to defeat it through lobbying and legal action (Shamir, 2004). Business organizations such as the National Foreign Trade Council and USA*Engage contend that the rising tide of ATS litigation represents a "unique but significant risk" to companies with a substantial U.S. presence, saddling them with heavy legal fees and putting them at a competitive disadvantage vis-à-vis foreign competitors in the international marketplace (Williams \& Conley, 2007). Business advocates and analysts warn that American MNEs might respond to the rising tide of transnational tort litigation by retrenching from developing countries, with grave consequences for the U.S. economy, ${ }^{26}$ and the economies of host countries.

U.S. government officials, meanwhile, warn that the exit of Western MNEs from fragile democracies in Asia, Africa, and the Middle East owing to escalating legal risk

compensation from Swiss banks for victims of the Holocaust and the case against Unocal in Burma (reportedly between $\$ 30$ and $\$ 60$ million). Other major settlements include those involving U.S. apparel and retail companies for allegations related to sweatshop labor in Saipan (\$20 million), Royal Dutch Shell for alleged human rights violations in the Niger Delta (\$15.5 million), and Yahoo! Inc. for divulging private information on political dissidents to the Chinese government (undisclosed amount) (Goldhaber, 2010).

${ }^{25}$ One of these cases (Bowoto v. Chevron) alleged that Chevron was complicit in the Nigerian military's violent crackdown against unarmed protesters at one of the company's offshore oil platforms. The other case (Romero v. Drummond Co.) was based on accusations that the Drummond Company conspired with Colombian paramilitary organizations to murder union leaders at one of its coal mines (Kropf, 2010).

${ }^{26}$ Hufbauer and Mitrokostas (2004) estimate that \$55 billion in U.S. foreign direct investment (FDI) could be deterred by ATS lawsuits, jeopardizing some $\$ 10$ billion in U.S. exports and 80,000 manufacturing jobs. Additionally, concerns over ATS liability could discourage foreignbased MNEs from investing in the U.S., costing thousands of additional American jobs. 
could have major U.S. foreign policy implications (Shamir, 2004). It could diminish Western strategic influence in countries regarded as important partners in the struggle against international terrorism, while opening the door to investment by state-owned firms from emerging nations that are less beholden to pressures from civil society groups (Schrage, 2003). ${ }^{27}$

But are the concerns of U.S. business and government leaders justified? Are the costs to corporations associated with defending themselves against transnational tort litigation indeed substantial? If so, according to the efficient market hypothesis (Fama, 1970), we might expect the market to discount a firm's stock price at the initiation of such litigation, in the absence of contemporaneous market-moving events, since the hypothesis holds that current prices of assets in the market reflect all available information about that asset. To date, no study has examined this question, although it has important implications for corporate strategy and public policy.

The objective of this study is to determine whether a relationship exists between the filing of ATS lawsuits and corporate share price. Given the proliferation of ATS lawsuits against corporations in recent years and the expectations that they will continue in the future, ${ }^{28}$ it is important to know whether the filing of new lawsuits is negatively

\footnotetext{
${ }^{27}$ Indeed, when Talisman Energy divested from an oil pipeline project in the Sudan in 2003 amidst intense stakeholder pressure, India's state-owned oil company ONGC Videsh Limited purchased its assets. The project continues to this day, but without the community development projects and transparency initiatives that Talisman claims it had implemented (Manhas, 2007). ${ }^{28}$ Numerous observers have predicted that ATS will become the next "litigation bonanza" for trial attorneys (Drimmer, 2010). And while an October 2010 ruling by the 2nd U.S. Circuit Court of Appeals that exempts corporations from liability for human rights abuses under ATS caused some to speculate about the imminent demise of this type of legal challenge (Goldhaber, 2010), subsequent decisions in other federal districts have affirmed the principle of corporate liability. Meanwhile, new ATS cases continue to be filed on a regular basis. In May 2001, for instance, an ATS case against Cisco Systems was filed in a California Federal District Court by an NGO on behalf of members of Falun Gong, claiming that Cisco helped design a firewall used by the Chinese government to censor the Internet and track political dissidents (Markoff, 2011). That
} 
associated with shareholder wealth and the magnitude of this relationship, if any. Empirical data of this sort may prove valuable to corporate decision makers contemplating overseas investments -- particularly in countries run by military governments, beset by war or ethnic conflict, or where violations of internationally recognized human and labor rights are commonplace.

If the majority of ATS suits are baseless, as suggested by corporate executives in interviews, congressional testimony, and court briefs (e.g., Drimmer, 2010; Fergenson \& Merrigan, 2007), then the market's reaction to them should be insignificant. Thus, claims that such lawsuits impose excessive costs, risks, and burdens on business could be treated with a high dose of skepticism. If it can be demonstrated, however, that the announcement of these lawsuits does trigger an immediate and significant decline in shareholder wealth, then MNE managers would have an incentive to undertake measures that could preempt such lawsuits, such as corporate social responsibility (CSR) programs and initiatives. ${ }^{29}$ After all, research has shown that firms adopting CSR initiatives prior to tactical attacks by activist groups can buffer themselves from potential criticism (Baron 2001; Baron \& Diermeier, 2007).

The remainder of this paper is organized as follows. Section 2 reviews the literature on corporate lawsuits and financial markets. Section 3 puts forth hypotheses informed by this literature. Section 4 discusses our data and methodology. Section 5

same month a California Federal Appeals Court revived a previously dismissed ATS lawsuit against DaimlerChrysler claiming the company was liable for abetting human rights abuses committed by Argentina's military dictatorship during the "Dirty War" of the 1970s (Stempel, 2011a).

${ }^{29}$ On the other hand, evidence of a litigation-share price link could encourage MNEs to redouble lobbying efforts to oppose such challenges and discredit the groups behind them (Shamir, 2004), make symbolic changes to policy while maintaining "business as usual" (David et al., 2007), or to divest from politically unstable countries (Hufbauer, 2009). 
examines our results. And Section 6 offers discussion, conclusions, and directions for future research.

\section{Literature Review}

Business researchers have long been interested in the question of whether and how legal disputes involving corporations affect company performance and shareholder wealth. An early study by Banks \& Kinney (1982) examined the market's reaction to footnote disclosures of pending lawsuits. They found that there was indeed a negative reaction to such disclosures. Frost (1991) corroborated these findings in a study using a larger sample size over a different time period. Bhagat, Brickley, \& Coles (1994) examined the market's reaction to lawsuits between corporations filed between 1981 and 1983. They found that defendant firms lost about one percent of their equity upon filing. Karpoff and Lott (1993) found that corporate defendants accused of fraud and anti-trust violations suffer significant wealth losses when the accusations were announced. The authors also found that criminal restitution, civil penalty, and court costs accounted for less than 10 percent of the shareholder wealth loss, and that the vast majority was due to reputational damage.

While analyses of the market's reaction to litigation between companies abound, research on the impact of civil lawsuits brought by private citizens against corporations is limited. Unlike inter-firm lawsuits, which primarily involve patent infringements and contract disputes, most lawsuits between individuals and corporations involve allegations of personal harms resulting from corporate negligence or misconduct (i.e., tort cases). 
In one of the few studies to consider these issues, Bhagat, Bizjak, \& Coles (1998) examined how lawsuits filed by governments, firms, and private citizens variously affect corporate share price. They observed that defendant firms experienced an average wealth loss upon filing of about $1 \%$ of market value of equity, or roughly $\$ 16$ million. Wealth destruction was largest for lawsuits filed by governments (-1.73\%), and smallest for those filed by other firms $(-0.75 \%)$; suits brought by private parties resulted in a loss of equity of $-0.81 \%$. In explaining their results, the authors hypothesized that governments have more leverage and resources at their disposal than other parties, and thus are seen by investors as more likely to prevail in a court battle. They also speculated that lawsuits filed by government agencies (e.g., environmental suits) may have more serious financial consequences for firms than other types of litigation (e.g., breach of contract). By contrast, Koku, Qureshi, \& Akhigbe (2001) found that lawsuits brought by individuals against corporate defendants had no significant wealth effect, although those against other firms did. This finding led the authors to conclude that firms should settle inter-firm lawsuits while litigating non-interfirm suits.

Koku (2006) found a difference in the way that the market responds to classaction and non-class action lawsuits. While investors tend to react negatively to the stocks of defendants in both cases, the reaction to class-action suits tends to be of a greater magnitude and occurs over a larger event window. Gande and Lewis (2009) too found significantly negative stock price reactions to shareholder-initiated class-action lawsuits.

Although the empirical evidence is far from conclusive, it does suggest that corporations typically experience a loss of shareholder value upon the filing of lawsuits 
against them, regardless of whether the plaintiff is a government, a corporation, or a private individual. Whether the filing of ATS lawsuits against MNEs by private plaintiffs results in the loss of shareholder wealth, however, remains an unanswered question. It is to this question that we now turn our attention.

\section{Hypotheses}

In the next section we develop a series of hypotheses on how the filing of ATS lawsuits may be related to firm stock market performance. These hypotheses consider characteristics of the firms targeted by litigation, the stakeholder groups that initiate them, and the nature of the lawsuits themselves.

1. Negative Market Reaction - Since most of the corporate ATS cases filed to date have been dismissed by federal courts on jurisdictional grounds, and the few that have made it to trial have resulted in verdicts for the defense, it is possible that the financial markets discount these lawsuits as insignificant events initiated by fringe activist groups and "global ambulance chasers" (Goldhaber, 2008). On the other hand, it is possible that market players do view the filing of ATS lawsuits as important occurrences that cloud a firm's financial prospects. After all, these cases typically involve allegations of complicity in grave human rights abuses and may generate serious reputational harms for defendant firms - especially since these legal cases are increasingly accompanied by sophisticated media campaigns designed to vilify the company (Manheim, 2001; Drimmer, 2010). Companies facing ATS litigation may need to take steps to publicize their side of the story and defend their reputations, including mobilizing public relations 
and crisis management teams and launching media campaigns -- all of which may come at a significant cost to the firm.

In addition to the possible image costs of ATS litigation for defendant firms, there are financial costs associated with either settling the cases or contesting them in court. Since ATS cases involve complex legal theories and arcane constitutional questions, they are typically expensive to litigate, requiring extensive preparation by in-house counsel or private attorneys. In the event that cases survive pretrial motions for dismissal or summary judgment and move into the discovery phase, legal costs escalate dramatically, as discovery may require extensive overseas travel and investigation, the deposing of foreign witnesses, the procurement of documents from foreign governments and militaries and their translation into English, and the hiring of expert witnesses in foreign and international law (Kropf, 2010). Defendants may also be compelled by the courts to provide public access to internal documents, emails, and other materials as part of the discovery process that are time-consuming to collect and may prove embarrassing to corporate officers (Baue, 2007). ${ }^{30}$ While defendants may prevail in lower courts, these rulings are subject to appeals and reversals, raising the prospect of protracted legal battles and escalating court costs.

The case of Talisman Energy in Sudan illustrates the arduous and costly path that ATS litigation can take. The firm, a large, Canadian independent oil and gas producer, was targeted in November 2001 with a $\$ 1$ billion class action lawsuit for alleged complicity in genocide and war crimes perpetrated by the Sudanese government against

\footnotetext{
${ }^{30}$ Davis (2008: 291) recounts an interview he conducted with ERI litigator Richard Herz who explained how a damning piece of evidence against Unocal was uncovered during the course of discovery: "We got an email where the Unocal guy says to the Total guy, 'we have no responsibility to control what the military does. We have our responsibility and they have theirs let's just admit there's a grey area."”
} 
Christians and non-Muslim minorities (Kobrin, 2004). In addition to aiding the repressive regime in Khartoum via royalties from an oil pipeline it helped operate as a minority partner in the Greater Nile Petroleum Operating Company (GNOPC), Talisman was accused of providing fuel, vehicles, aircraft, and runways for the Sudanese military, which used them to carry out bombing raids on civilians (Shamir, 2004). The legal case against Talisman was but one facet of a larger divestment campaign that included boycotts, protests, and shareholder resolutions. Spearheaded by the American AntiSlavery Group, a Boston-based NGO, the campaign generated a barrage of negative press and prompted large investment funds including TIAA-CREF, CALPERS, and the New York City Pension Fund to sell their Talisman shares. The U.S. Congress also considered legislation that might have resulted in Talisman's shares being delisted from the New York Stock Exchange (Kobrin, 2004).

Talisman ultimately sold off its Sudanese assets in late 2002, citing "shareholder fatigue," but this did not end its legal ordeal. In March 2003 a federal district judge denied Talisman's request for dismissal, ruling that the case could proceed. Several more years of litigation ensued. In 2006, a district court granted summary judgment for Talisman, seemingly vindicating the company. But plaintiffs promptly appealed the ruling, initiating a new round of litigation. The appeals court upheld the dismissal in 2009, but the plaintiffs have since filed a petition with the U.S. Supreme Court, which may yet take up the case. The case against Royal Dutch/Shell for its alleged complicity in the execution of Ogoni human rights activist and Nobel Peace Prize nominee Ken SaroWiwa by Nigeria's military followed a similar trajectory, marked by dismissals and 
reversals, and ultimately culminating in a $\$ 15.5$ million settlement on the eve of the trial some 13 years after the initial lawsuit was filed. ${ }^{31}$

Beyond the reputational damage and legal costs, defendants in ATS cases face the possibility of sizable compensatory and punitive damages in the event that a jury finds it liable. This is not an idle threat given the sympathy American juries have shown toward individual plaintiffs in non-ATS tort cases (Koku et al., 2001) and ATS cases involving private individuals and government defendants. Indeed, in 1995 a U.S. jury awarded Filipino citizens nearly $\$ 2$ billion in damages in an ATS case against the estate of former dictator Ferdinand Marcos (Latham \& Watkins, 2010). Plaintiffs may also attempt to recover attorneys' fees and seek the disgorgement of profits, further adding to the potential legal liability that defendant firms face (Fergenson \& Merrigan, 2007).

Even if these efforts fail, MNEs facing litigation may experience higher insurance premiums and higher costs of capital (Frynas, 2004), and in some cases, the loss of customers, as illustrated by a Danish energy firm's recent announcement that it was halting coal purchases from Drummond Co. pending the resolution of a case involving alleged complicity in the murder by right-wing paramilitaries of labor activists at one of its mines in Colombia (Cooper, 2006). Finally, allegations of grave and systematic abuses may invite unwanted attention from policymakers and result in regulatory sanctions that negatively impact future cash flows (Eesley \& Lenox, 2006).

Thus, it is possible that market players will view the filing of an ATS lawsuit against a corporation as bad news that will diminish firm value by diverting resources

\footnotetext{
${ }^{31}$ As Goldhaber (2009) observes, it is quite likely that Royal Dutch Shell spent significantly more in fees to its legal counsel than it did on the settlement, and that it would have spent more again on the trial and subsequent appeals.
} 
from productive activities to litigation and public relations, driving up operating costs, and chasing away customers and investors. Financial markets might also surmise that the reputational damage associated with these suits could adversely affect the firm's ability to raise money on capital markets and attract and retain top managerial talent, triggering a decline in future earnings expectations.

$H 1$ - News of the initial filing of an ATS lawsuit against a firm will result in a negative stock market reaction.

2. Industry: It has been shown that investors react to sudden and unexpected market events by penalizing firms in industries associated with these events. For instance, in the aftermath of the anti-globalization protests that derailed the 1999 WTO global trade negotiations, investors sold shares in firms in industries considered to be "environmentally damaging" (i.e., mining, steel, chemical, pulp and paper, and energy) and "labor abusing" (i.e., toys, apparel, and footwear) (Epstein \& Schnietz, 2002). Investor reaction appears to have been motivated by concerns that the success of these protests might trigger a wave of anti-business regulation or consumer boycotts against firms in these industries. A similar logic could apply to the filing of ATS lawsuits; investors might presume that firms in industries targeted most often by this type of litigation could be harmed in the future by stricter regulation or a consumer backlash.

Although firms from a wide variety of industries, including chemicals, pharmaceuticals, financial services, telecommunications, agriculture, and food and beverages, have been sued under ATS in recent years, those involved in petroleum and 
gas exploration and mining (i.e., extractive companies) and heavy construction have been the most frequent targets (Kropf, 2010). This may be because extractive companies and the firms that help build the infrastructure for their projects typically have limited choices about where they can invest -- they must go where the natural resources are. Since these resources are often buried beneath the soil in developing countries run by authoritarian regimes or torn by strife and internal conflict, MNEs involved in the extraction and production of natural resources may be particularly vulnerable to ATS litigation (Kaeb, 2008).

Furthermore, since MNEs seeking to exploit mineral resources in foreign countries must often partner with state-owned enterprises as a condition of entry and hire government security forces to police these projects, and these security forces typically have little human rights training, extractive MNEs may be disproportionately exposed to ATS litigation (Drimmer, 2010). Finally, since extractive firms and their construction industry affiliates are typically held in low regard by the public, and seen in some quarters as exploitative and corrupt, investors might determine that these firms would be unsympathetic defendants in the event that a case goes to a jury trial (Kropf, 2010), leading them to anticipate declines in future cash flows, thereby adversely affecting corporate share price.

H2 - Lawsuits against extractive companies will have a larger negative impact than those against non-extractive firms. 
3. Reputation for Social Responsibility - There is a large and growing management literature that examines the link between a firm's commitment to social responsibility, broadly understood as discretionary activities designed to improve social conditions (Mackey, Mackey, \& Barney, 2007), and its financial performance (Godfrey, Merrill, \& Hansen, 2009). A primary aim of this literature is to determine whether firms regarded as socially responsible, based on evaluations of third-party entities, ${ }^{32}$ are more profitable than their less socially- and environmentally-minded peers. Although debates rage over the methodologies and measures used in these studies, the consensus is that "virtuous" firms do tend to perform better over time than their non virtuous counterparts (Doh et al., 2010; Margolis \& Walsh, 2003; Orlitzky, Schmidt, \& Rynes, 2003), and may also generate enhanced support from consumers, employees, and investors (Waddock \& Graves, 1997), thereby laying the foundation for sustained competitive advantage (Hill \& Keim, 2001).

While the idea that a reputation for social responsibility can serve as a source of economic value has gained currency, few researchers have examined the social responsibility-financial performance link in the face of organizational uncertainty and crisis. Does having a reputation for social responsibility preserve shareholder wealth in the event of a negative reputation event, such as a legal challenge by secondary stakeholder groups? It is possible that it does. After all, past empirical research has shown that a reputation for social responsibility can buffer a firm from external financial and

\footnotetext{
${ }^{32}$ A variety of third-party entities publish CSR and corporate citizenship rankings. The list includes journals (e.g., Fortune and Business Ethics magazines), mutual funds, private companies, and non-profit organizations. The two most widely used social indices are the Domini social index, created by KLD Research \& Analytics, Inc., and the Calvert social index, created by Calvert Investments (Doh et al., 2010).
} 
political turbulence. Jones, Jones \& Little (2000) found that firms with a high score on Fortune's Most Admired Companies survey experienced smaller declines in shareholder value during the stock market crash of 1989 than did those without, while Schnietz \& Epstein (2005) reported that firms with a reputation for social responsibility experienced proportionately smaller losses in shareholder value in the aftermath of the failed 1999 WTO talks.

These and other studies examining the risk management ramifications of social responsibility initiatives (e.g., Love \& Kraatz, 2009; Doh et al., 2010) suggest that a reputation for social responsibility may serve as a source of "moral capital" (Godfrey, 2005) or "reservoir of goodwill" (Jones et al., 2000) in times of crisis, providing "insurance-like protections" (Godfrey et al., 2009), and cushioning the firm from potentially negative outcomes. A reputation for social responsibility may also facilitate a firm's return to normalcy after a negative event, thereby serving as a source of organizational resilience (Beer, 2009; Sheffi, 2005). As such, we expect that investors will perceive the securities of MNEs with reputations for social responsibility to be less risky than those of firms without such reputations, and that these virtuous firms in turn will experience a smaller adverse market reaction upon the filing of ATS lawsuits. We thus propose:

H3 - Firms with reputations for social responsibility will experience a smaller negative stock market reaction upon the filing of an ATS lawsuit than firms without such reputations. 
4. Identity of Plaintiff's Legal Representation - Theory suggests that managerial attention to stakeholder demands is conditioned by the group's salience, as defined by its power, legitimacy, and the urgency of its demands (Mitchell et al., 1997). It is logical that investors would be swayed by these attributes as well in assessing the potential threat a lawsuit poses to future earnings. While NGOs and other secondary stakeholder groups have little or no resource leverage over focal firms and hence little power (Pfeffer \& Salancik, 1978; Frooman, 1999), they often have high legitimacy in the eyes of the public (Yaziji, 2004; Yaziji \& Doh, 2009). Legitimacy has been defined as social acceptance resulting from adherence to social norms and expectations (Deephouse \& Carter, 2005), and it is reasonable to presume that lawsuits filed by groups with high levels of legitimacy would carry more weight with investors than those filed exclusively by groups with low legitimacy, such as trial attorneys, who are renowned for being unscrupulous and opportunistic. ${ }^{33}$ After all, litigation initiated by high legitimacy groups are likely to be seen as more credible by the primary stakeholders of the firm (e.g., customers, employees, suppliers) as well as by the media and government regulators, which may increase the economic and reputational risks associated with these lawsuits.

NGOs have other assets that may give them an advantage over private firms in civil litigation, including dense networks of relationships with individuals and advocacy groups both domestically and abroad (Rowley \& Berman, 2000; Doh, Newburry, \&

\footnotetext{
${ }^{33}$ In practice, NGOs and private law firms often work together on ATS cases, along with public interest lawyers. For example, the ATS case against Texaco (Aguinda v. Texaco) was filed on behalf of members of three indigenous tribes from Ecaudor by an Ecuadorean attorney based in the U.S., and American class action law firm, a group of Boston-based law professors, and U.S. and foreign NGOs, including the Massachusetts Environmental Law Society, Earth Justice International, and Amazon Watch (Shamir, 2004).
} 
Teegen, 2003). These networks may facilitate the gathering of evidence required to prosecute a successful court case (Davis, 2008). NGOs may also have dedicated legal staffs with extensive knowledge of human rights law and experience litigating ATS cases as well as connections to other NGOs will similar resources and capabilities, and these resources may facilitate the development of successful legal cases (Davis, 2008). Moreover, since NGOs tend to draw people who are morally engaged and committed to the principles their organizations stand for (della Porta \& Mario, 1999), NGOs may be more willing than private firms to pursue cases that take years to develop and are unlikely to result in favorable verdicts or lucrative settlements. Finally, since NGOs typically have limited resources, they tend to be highly selective about the legal cases they take on, and this selectivity may result in more successful litigation (Davis, 2008).

H4 - ATS lawsuits filed with NGO support will have a larger the negative stock market reaction than those filed exclusively by private law firms.

5. Nature of Claims - In addition to paying attention to the identity of the stakeholder group mounting the anti-corporate challenge and the legitimacy they possess, theory suggests that managers consider the nature of the claims being brought against the target firm, with those related to issues affecting primary stakeholders having greater urgency than those involving issues of concern to more distant stakeholders (Mitchell et al., 1997; Clarkson, 1995; Hillman \& Keim, 2001). Given that workers are a stakeholder group critical to organizational survival and financial performance, one might presume that investors, like managers, would view lawsuits alleging overseas labor violations as a 
particularly serious economic threat. In fact, it is possible that investors would view labor-related lawsuits as an even greater threat than lawsuits alleging more serious human rights crimes, including kidnapping, torture, and murder, perpetrated against nonworkers. After all, a broad public consensus appears to have developed in the U.S. in the wake of the NGO-led anti-sweatshop campaigns of the 1990s, that companies have a moral responsibility for the treatment of workers in foreign factories, even when these workers are employed by subcontractor firms (Soule, 2009; Spar \& LaMure, 2003). No such consensus appears to yet exist over corporate obligations with respect to the environment and the treatment of more distant stakeholders (e.g., protestors). It is also possible that investors view labor-oriented lawsuits as a prelude to other anti-corporate activities that may negatively affect firm financial performance such as protests, boycotts, and strikes (King \& Soule, 2007). Based on this, we propose the following:

H5 - ATS lawsuits premised on labor violations will generate a larger negative stock market reaction than those premised on non-labor issues.

6. Number of Defendants - Theory suggests that certain stakeholder actions are more threatening to firms than others because they signal to investors that the public no longer trusts the company (King \& Soule, 2007). Such a lack of trust, or loss of legitimacy, may undermine the company in its dealings with consumers, employees, suppliers, and investors, thereby causing market players to anticipate a future loss in cash flow (Fombrun \& Shanley, 1990; Fombrun, 1996). One possible indicator of threat with respect to civil litigation is the number of corporate defendants named in the lawsuit. 
Although many ATS lawsuits name a single corporate defendant, others target two or more firms, and a few -- including those related to Apartheid-era crimes in South Africa - involve more than two dozen firms and damage claims in the billions of dollars (Fergenson \& Merrigan, 2007). And while the resources that can be marshaled by multiple corporate defendants are likely greater than those available to a single corporate defendant, giving these defendants an edge in a protracted legal dispute, most ATS cases to date have been either dismissed or settled prior to a trial, thereby negating some of these resource-based advantages. In short term, it is likely that the extensive negative media attention these multi-defendant lawsuits tend to generate, and the possibility of a costly settlement, will harm investor sentiment toward target companies and depress their share price. We therefore propose:

H6 - ATS lawsuits involving multiple corporate defendants will generate a larger negative stock market reaction to each defendant than those involving a single corporate defendant.

X. Methodology

Data Collection Technique

The sample for this study is drawn from a variety of data sources. Information on all ATS lawsuits involving MNEs between 1993 and 2010 was gathered using the LexisNexis and Westlaw legal databases. We selected 1993 as the start date for our study since a landmark ATS lawsuit was filed that year by Ecuadorian plaintiffs with the 
assistance of NGOs against Texaco for alleged human rights violations and environmental crimes committed during its nearly three decades of operations in the Ecuadorian Amazon (Aguinda v. Texaco, Inc.). ${ }^{34}$

Our legal research was supplemented by searching business news abstracts in Bloomberg Law, Lexis-Nexis, and ProQuest for articles about the filing of civil lawsuits against corporations published in the major international business press (e.g., The Wall Street Journal, The New York Times, and The Financial Times) and wire services (e.g., Bloomberg, Dow Jones, Reuters, and the Associated Press). Keywords searches were conducted using terms such as "alien tort," "civil litigation," "lawsuit," "human rights," and individual company names, obtaining information on ATS lawsuits involving 141 multinational corporate defendants. Thus, our initial sample consisted of 141 events. This was reduced to 102 events after eliminating privately held corporations, companies not listed on a major U.S. stock exchange, and firms with gaps in their market data. Following the methodology used in past event studies (e.g., Godfrey et al., 2009; Schnietz \& Epstein, 2005), we also screened for possible confounding events such as announcements of earnings, new products, and mergers and acquisitions occurring 3 weeks before the time news of the lawsuit became public, eliminating 6 additional cases.

Our final sample consists of 92 cases involving 67 MNEs. See Appendix A for a list of the cases, defendants, and filing dates. Our sample includes firms cited as defendants in large class-action lawsuits involving dozens of multinational companies such as the South African Apartheid litigation (Khulamani v. Barclay's National Bank

\footnotetext{
${ }^{34}$ While the Aguinda ATS case was dismissed by a U.S. court in 1993, related charges were brought in Ecuador under Ecuadoran law, and in 2011 an Ecuadorian court found Chevron (which acquired Texaco in 2001) liable for $\$ 17$ billion in damages (Carroll \& Gullo, 2011).
} 
Ltd.), as well as cases involving a single corporate defendant (e.g., Pfizer v. Adbullahi). Our sample also includes several companies that had more than one ATS lawsuit filed against them during the time series (e.g., The Coca-Cola Company, Dow Chemical, Chiquita, and Occidental Petroleum). The size of the firms in our sample ranges from a market cap of $\$ 126$ million (Cutter \& Buck) to $\$ 396$ billion (Exxon Mobil). The average market cap is $\$ 60.19$ billion. Tables 2 and 3 provide descriptive statistics and correlations for all independent variables.

TABLE 2: Descriptive Statistics

\begin{tabular}{|l|r|r|r|r|r|}
\hline & $\mathrm{N}$ & Minimum & Maximum & Mean & Std. Deviation \\
\hline MCap & 61 & 126.08 & 396160.00 & 60194.1428 & 76543.20802 \\
Valid N (listwise) & 61 & & & & \\
\hline
\end{tabular}


TABLE 3: Correlation Matrix

Correlation Matrix

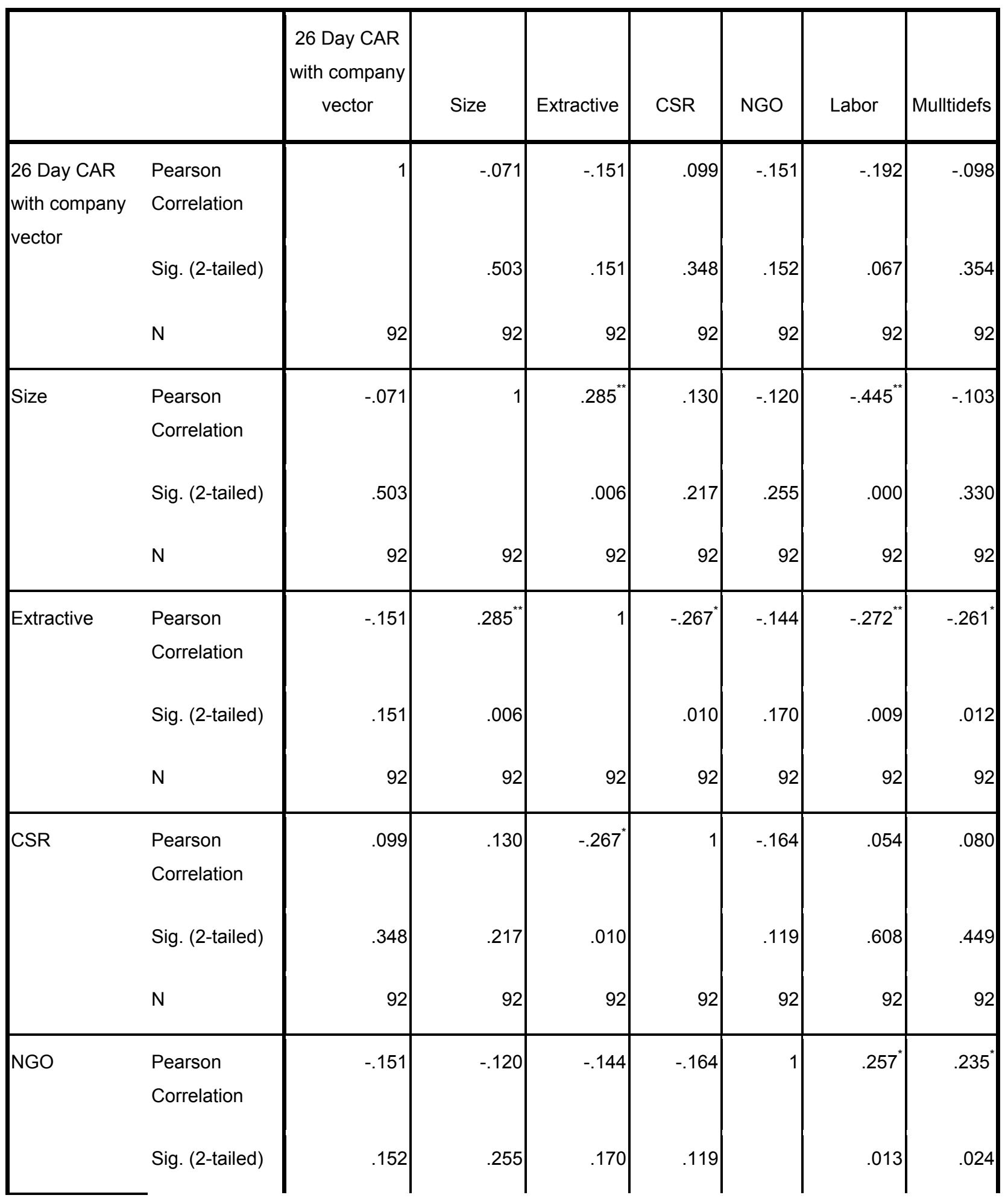




\begin{tabular}{|c|c|c|c|c|c|c|c|c|}
\hline & N & 92 & 92 & 92 & 92 & 92 & 92 & 92 \\
\hline \multirow[t]{3}{*}{ Labor } & Pearson & -192 & $-.445^{* \prime}$ & $-272^{\prime \prime}$ & .054 & $.257^{*}$ & 1 & .224 \\
\hline & Sig. (2-tailed) & .067 & .000 & .009 & .608 & .013 & & .032 \\
\hline & $\mathrm{N}$ & 92 & 92 & 92 & 92 & 92 & 92 & 92 \\
\hline \multirow[t]{4}{*}{ Mulltidefs } & Pearson & -.098 & -103 & $-261^{*}$ & .080 & $.235^{*}$ & $.224^{*}$ & 1 \\
\hline & Correlation & & & & & & & \\
\hline & Sig. (2-tailed) & .354 & .330 & .012 & .449 & .024 & .032 & \\
\hline & $\mathrm{N}$ & 92 & 92 & 92 & 92 & 92 & 92 & 92 \\
\hline
\end{tabular}

${ }^{* *}$. Correlation is significant at the 0.01 level (2-tailed).

*. Correlation is significant at the 0.05 level (2-tailed).

Although all of the cases in our data set involve allegations of grave human rights abuses or environmental misconduct, most of the cases cluster around one of the following issues: 1) violations of international labor standards, including forced labor, child labor, human trafficking, sweatshop labor, and systematic employment discrimination; 2) environmental crimes, including pollution of groundwater and the disruption of ecosystems; 3) harms committed by state security forces, including murder, torture, rape, genocide, kidnapping, and unlawful detention; 4) harms committed by paramilitary groups including intimidation, torture, and murder; and 5) support for the Apartheid regime in South Africa. Figure 5 shows the distribution of cases in our data set according to issue. ${ }^{35}$

35 It should be noted that many lawsuits do not fit neatly into only one of our categories. An ATS lawsuit filed in 2000 against British mining firm Rio Tinto for its activities on Bougainville Island in Papua New Guinea is a case in point. The suit claims that the company requested and 
Figure 5: ATS Lawsuits by Issue

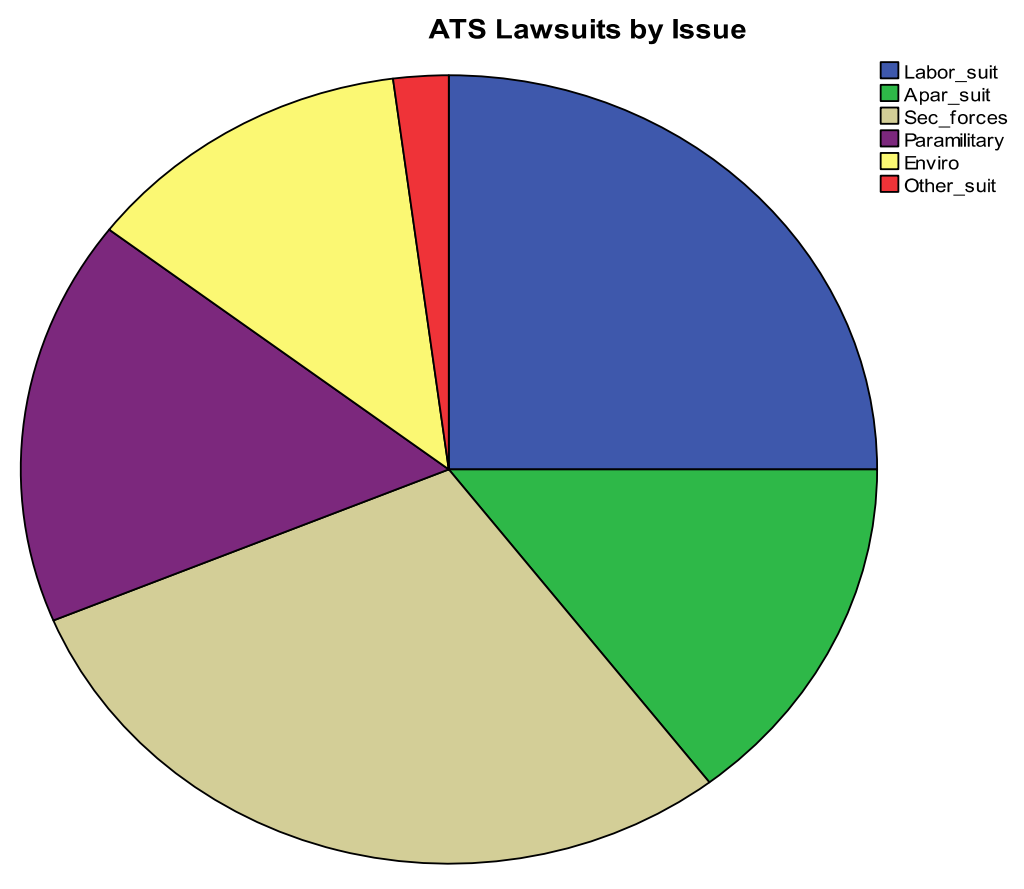

To account for the potential confounding of non-independence of measurement, a company vector was generated, as suggested by Kerlinger and Pedhazur (1973), McNeil, Newman, and Kelley (1996). This variable will allow one to determine the effect of the independent variable of interest (lawsuit) that is independent of company differences due to multiple lawsuits filed against individual companies. We did not include legal appeals as events in our data set, as our focus is the market's reaction to the onset of new litigation.

obtained government support to suppress a local uprising against environmental damage caused by the firm's copper mining operations, as well as its racially discriminatory hiring practices (Kaeb, 2008), and as such, this case is included in three of our categories: "Security forces," "Environment," and "Labor practices." 
While concern could be expressed about what may at first appear to be the small sample size, it is notable that our total sample size is larger than those used by previous studies of similar issues. For example, in their study of the relationship between boycotts and boycott threats and target firm share price, Koku et al., (1997) used a sample size of 54. Event studies of boycotts by Pruitt and Friedman (1986) and Pruitt, Wei, and White (1988), meanwhile, examined 21 and 16 events, respectively.

\section{Statistical Analysis}

We test our hypotheses using an event study methodology and ordinary least squares (OLS) regression (Fraas \& Newman, 2003; Tabachnick \& Fidell, 2007). Event studies use the past performance of a firm's stock to calculate the extent to which its performance on and around an event deviates from expected performance, and then test whether this deviation is statistically significant (McWilliams \& Siegel, 1997). Developed by finance and accounting scholars (Brown \& Warner, 1985), the event-study methodology is based on the efficient market hypothesis, which posits that markets are efficient in reflecting new information and therefore a firm's stock price will quickly adjust to the new information, reflecting all available information about the firm's current and future profit potential (Muth, 1961; Fama 1970). If any new information resulting from the unexpected event is believed to affect a firm's current or future earnings, the security price changes as soon as the market learns of the event. Thus, stock prices are viewed as reliable indicators of a firm's value (Agrawal \& Kamakura, 1995).

In addition to the assumption of efficient markets, the event-study methodology assumes that the events under study are unanticipated, and that no confounding events 
occur during the event window that could affect share price (McWilliams \& Siegel, 1997). While the event-study methodology has its detractors, even critics such as Schleifer (2000) acknowledge that the basic assumptions underpinning the methodology are valid, that when executed properly it produces robust results, and that these studies have significantly enhanced our understanding of stock market reaction to external events.

In recent years management and IB researchers have used event studies to examine the the stock market's reaction to a variety of unanticipated events -- from product recall announcements (Davidson \& Worrell, 1992) and plant closings (Clinebell \& Clinebell, 1994) to congressional votes on international trade-related legislation (Oxley \& Schnietz, 2001). Event studies involve four basic steps: 1) Defining the event and announcement period; 2) Measuring the stock's return during the announcement period; 3) Estimating the expected return of the stock during the announcement period in the absence of the announcement (i.e., normal returns); and 4) Computing the abnormal return and testing its statistical significance (Bhagat \& Romano, 2007). Most event studies follow up this initial analysis by performing regression analysis to determine whether certain variables of interest are related to the change in stock price (Godfrey et al., 2009).

There are several different models used to derive normal returns, but the market model is the one most commonly used in management research (MacKinlay, 1997). This model is based on the argument that the expected return on an asset in the market is linearly related to the contemporaneous return on the market portfolio, such that: 


$$
\mathrm{Rit}=\alpha i+\beta i \mathrm{R} m k t+\mathrm{e} i t \quad \text { (equation } 1)
$$

In this equation, Rit captures the expected return for the $i$ th firm's share price on that day controlling for market-based fluctuations. Rmkt is the return for the overall market portfolio at time $t$, as defined by the Center for Research in Security Prices (CRSP) equally-weighted stock market index; $\alpha i$ and $\beta i$ are firm specific and timeindependent parameters; eit is the error term for stock $i$ at time $t$. Following King \& Soule (2007) and Zajac \& Westphal (2004), we regress stock market returns for the firms in our sample against returns on a broad market portfolio for a period beginning 239 trading days before the event and ending 21 days before the event. We then use the parameters from equation 1 to forecast expected returns for a period of 20 days prior to the event $(t$ 20) to 5 days after the event $(t+5) \cdot{ }^{36}$ We include 5 days following the announcement to ensure that any change in stock price is not temporary or the result of supply and demand adjustments following the announcement (Doh et al., 2010). We then calculate abnormal returns ARit, by subtracting the actual returns, obtained from CRSP, from the forecasted returns, as shown in equation 2.

$$
\mathrm{AR} i t=\mathrm{R} i t-(\alpha i+\beta i \mathrm{R} m k t) \quad(\text { equation } 2)
$$

\footnotetext{
${ }^{36}$ It is important that there is no overlap between the estimation period and the event window so as to prevent the "normal" returns (i.e., those that could have been expected had the event not taken place) from being influenced by the event itself and thereby distorting the abnormal return (MacKinlay, 1997). Our estimation period does not overlap with the event or the preannouncement period, as it ends 21 trading days before the event, and a day before the beginning of the preannouncement period.
} 
In the above equation, ARit is the abnormal return $t$ of security $i$, Rit and Rmkt are the returns on $t$ of security $i$ and the market portfolio, respectively. The parameters $\alpha i$ and $\beta i$ are estimated by an OLS regression. Each firm's abnormal returns are then standardized and cumulated over the event interval to derive the cumulative abnormal return (CAR $i$ ), providing a measure of how much the market value of a firm changed as a result of the event. Cumulative abnormal returns of all firms in the sample are then summed, and the sum is divided by the number of firms to derive the mean CAR, which is then standardized and tested for significance (McWilliams \& Siegel, 1997).

Most event studies begin calculating the event window prior to the day of the event because of the tendency for investors to receive news about the impending event from private, non-news sources and social networks and act upon this news (Schleifer, 2000; Zajac \& Westphal, 2004). This is particularly germane in the case of lawsuits since plaintiffs often use the media as a vehicle to communicate with potential parties and leak information to influence public opinion and gain leverage in legal proceedings (Koku, 2006). As such, we calculate CAR based on a 26-day window, which is consistent with other research examining the shareholder wealth implications of stakeholder actions including boycotts (Pruitt \& Friedman, 1986; Koku, Akhigbe, \& Springer, 1997) and protests (Epstein \& Schnietz, 2002; King \& Soule, 2007). However, to enhance the probability that our findings were not merely a function of the length of the event window, we calculated CAR for three additional windows: 21 days (day -15 to +5$), 11$ days $(-5,+5)$, and two days (day -1 to 0 ). The smaller windows provide a more conservative test (King \& Soule, 2007), but may not capture the full market reaction to the lawsuit announcement. Because we were interested in only investors' initial reactions 
to the filing, we used a short window ( +5 days) following the announcement to minimize the possibility that confounding events, including the company's actions in response to the lawsuit, were captured in our event window (King \& Soule, 2007).

\section{Dependent Variable}

Our dependent variable in this study is mean CAR, which is a standard measure of abnormal stock price return in event studies (Brown \& Warner, 1985; Zajac \& Westphal, 2004). CAR represents the idiosyncratic change in shareholder value, as represented by stock price, surrounding the announcement of the lawsuit. Stated differently, CAR is the sum of the daily differences between the firm's actual and expected return. If the market believes the lawsuit undermines the firm's future financial prospects, then CAR should be negative and significant; if investors determine that the legal action poses no real financial threat to the firm, CAR should not be significantly different from zero.

We derived CAR by gathering daily market returns from CRSP through the Eventus software program available through the Wharton Research Data Service. Following standard event study methodology, we selected the date of the first public announcement of the litigation in the major business press as the event date (Day $t=0$ ). In many cases, the first news item appeared on the day of the filing. In others it appeared on the next trading day, or several days later. But in some cases information about an impending lawsuit was published prior to the actual filing. In these cases, the date of the pre-filing news item was used as the event date. 


\section{Independent Variables}

In addition to assessing the effect of ATS lawsuit announcements on target firm stock price to test hypothesis 1, we examine whether certain characteristics of the defendant, the plaintiff, and the legal case itself moderate the market's reaction to these lawsuits, to test hypotheses 2-6. We thus performed a regression with a set of predictor variables, using the 26-day CAR as the dependent variable.

According to hypothesis 2, firms involved in mineral extraction and production should experience larger negative returns upon announcement of an ATS lawsuit than firms in other sectors because of the close ties these corporations often have to authoritarian governments and militaries, their generally poor public image, and the possibility that litigation may force these firms to settle or curtail otherwise profitable activities. To assess this hypothesis, we create a dichotomous industry variable based on whether the firm's primary business activities involve mineral extraction or production (via the provision of construction services) using the two-digit standard industrial classification (SIC). The SIC classificatory scheme is commonly used in the management and strategy literatures (Russo \& Fouts, 1997; Kale, Dyer, \& Singh, 2002; Epstein \& Schnietz, 2005). Firms involved in extraction or construction are coded with a 1, and include those in the metal mining (10), coal mining (12), oil and gas extraction (13), non-

metallic minerals, except fuels (14), general building contractors (15), heavy construction, except building (16), and special trade contractors (17) categories; firms not involved in these activities are coded with a 0 .

To test hypothesis 3, which predicts that firms with a reputation for social responsibility will experience smaller negative returns upon the announcement of ATS 
lawsuits than firms without such reputations, we include a dichotomous variable based on whether the firm was listed on the Calvert Social Index (CSI) in the year prior to that in which the lawsuit was filed (CSI-listed firms are coded 1; non-listed firms 0 ). The CSI is one of the most widely recognized indices of socially and environmentally responsible corporations. Its membership includes companies that meet rigorous standards for sustainable and socially responsible practices and are selected from the universe of approximately the 1,000 largest U.S. companies, based on total market capitalization, included in the Dow Jones Total Market Index. The Index is reconstituted once a year. As of May 2011, 666 firms comprised the index. While not a reputation rating per se, the CSI provides inputs for stakeholder groups in their formulation of a firm's reputation for social responsibility, and thus represent a good proxy for reputation - and one that has been used by other management researchers (e.g., Doh et al., 2010).

To test hypothesis 4, that lawsuits filed by NGO plaintiffs or with NGO representation will trigger a larger negative stock price reaction in target firms than those filed by private law firms, we include a dichotomous variable based on whether the plaintiff's legal counsel includes an NGO. Those cases involving NGO participation are coded 1; those filed by private firms without any NGO involvement are coded 0 .

To test hypothesis 5, that lawsuits involving allegations of labor violations will result in a larger negative stock market reaction than those involving other issues, we include a dichotomous variable based on whether the principal legal claim centers on violations of internationally recognized labor standards, such as the use of forced labor, child labor, and anti-union activities. Cases involving labor claims are coded 1; all others are coded 0 . 
To test hypothesis 6 , that lawsuits involving multiple corporate defendants will result in a larger negative stock market reaction than those involving a single corporate defendant, we include a dichotomous variable based on the number of defendant firms named in the litigation. Those cases involving a single corporate defendant are coded 0 ; those with multiple corporate defendants are coded 1.

\section{Control Variables}

Because large firms differ from small and medium-sized firms in fundamental ways, including visibility (Rindova et al., 2006), access to resources (Pfeffer \& Salancik, 1978), political influence (Hillman \& Hitt, 1999), and exposure to risk (Godfrey, 2005), firm size is often used as a control variable in empirical studies in the strategy and IB literatures (e.g., Hillman \& Keim, 2001; Rehbein, 2004; Strike et al., 2006). Following this literature, we control for firm size using the firm's market capitalization (market cap), which is a measurement of business value based on share price and number of shares outstanding. A firm's market cap represents the market's view of its stock value and is a determining factor in stock valuation. Since market cap can vary significantly from year to year, we generated a dichotomous variable based on whether the firm's average market cap was greater or less than $\$ 10$ billion over a 5 -year period beginning in May 2006, and ending in May 2011. Firms with an average market cap of less than $\$ 10$ billion are coded 0 ; those with an average market cap exceeding $\$ 10$ billion are coded 1 . The final regression model is as follows:

$$
\mathrm{AR} i t=\alpha 0+\beta 1 S Z+\beta 2 E X T+\beta 3 C S R+\beta 4 N G O+\beta 5 L A B+\beta 6 N D+\mathrm{e}
$$


Where ARit is the abnormal return for firm $i$ over the 26-day event window (-20, $+5), S Z$ is the control variable for the size of the defendant firm, as measured by its market capitalization, $E X T$ is the dummy for whether the target company is in the extractive industry, CSR is the dummy for whether the target company has a reputation for social responsibility, $N G O$ is the dummy variable for whether the plaintiff in the lawsuit is represented by an $\mathrm{NGO}, L A B$ is the dummy variable for whether the lawsuit involves allegations of international labor violations, and $N D$ is the dummy variable for whether the lawsuit names more than one corporate defendant.

XI. Results

To test hypothesis 1 , that the announcement of ATS lawsuits lead to a negative stock market reaction, we assessed the statistical significance of the CAR for four event windows: 2 -days $(-1,0), 11$-days $(-5,+5), 21$-days $(-15,+5)$, and 26 -days $(-20,+5)$. Table 4 shows the test statistics for CAR for these windows, using the Market Model, Equally Weighted Index. ${ }^{37}$

\footnotetext{
${ }^{37}$ Since our sample includes many large-cap firms, we also ran our analysis using a ValueWeighted Index (Market Model). These results were not substantially different, although the CAR in the 11-day window was no longer significant, and the size of the negative CAR in the 21 and 26 day windows was smaller $(-1.13 \%)$ and $(-0.52 \%)$, respectively.
} 
TABLE 4: Test Statistics for Cumulative Abnormal Returns

\begin{tabular}{|l|l|l|l|l|l|l|}
\hline 1 & 2 & 3 & 4 & 5 & 6 & 7 \\
\hline $\begin{array}{l}\text { Event } \\
\text { Window }\end{array}$ & Days & $\mathrm{N}$ & $\begin{array}{l}\text { Mean } \\
\text { CAR }\end{array}$ & CAAR & Patell Z & p-value \\
\hline 26-day & $(-20,+5)$ & 92 & $-4.76 \%$ & $-4.88 \%$ & -4.669 & $<.0001^{* *}$ \\
\hline 21-day & $(-15,+5)$ & 92 & $-4.39 \%$ & $-4.50 \%$ & -4.792 & $<.0001^{* *}$ \\
\hline 11-day & $(-5,+5)$ & 92 & $-1.52 \%$ & $-1.59 \%$ & -2.344 & $<.001^{* *}$ \\
\hline 2-day & $(-1,0)$ & 92 & $-0.61 \%$ & $-0.35 \%$ & -1.203 & $<.1144$ \\
\hline
\end{tabular}

Columns 1 and 2 show the different event windows and the specific days before and after the event included in these windows, respectively. The third column shows the number of cases. Column four provides the mean CAR, which is expressed as a percentage and represents the average cumulative percentage change in a stock price below that which was expected. Column 5 shows the cumulative average abnormal return (CAAR), which is an alternative way of signifying the average change and can be interpreted as the cumulative percentage change in the daily means of the firms' abnormal returns (King \& Soule, 2007). Column 6 contains Patell's Z, a standard measure of statistical significance in event studies, and column 7 shows the p-value.

Our results show that in the 2-day window, the stock market's reaction is negative, as expected, but not significant. The mean CAR is $-0.61 \%$, with a Patell's Z value of -1.203 . These results are consistent with those reported by Koku (2006), who examined class-action lawsuits filed by private parties against corporations and did not find a significant market reaction on the announcement date, and Koku et al. (2001), who analyzed lawsuits filed against corporate defendants by individuals and failed to find significance during a 2-day window surrounding the announcement. 
Koku (2006) did, however, report significance when using a wider event window, as do we. Consistent with our expectations, the mean CAR is negative in all three of our longer windows and statistically significant. Stock prices of targeted firms declined on average by $4.76 \%$ during the 26 -day window $(-20,+5)$, representing a loss in shareholder wealth of roughly $\$ 2.86$ billion for the average firm in our sample. Likewise, the share price of targeted firms declined on average by $4.39 \%$ during the 21 -day window (-15, $+5)$, and by $1.52 \%$ during the 11 -day window $(-5,+5)$, representing losses in shareholder wealth of roughly $\$ 2.6$ billion and $\$ 912$ million, respectively, for the average firm in our sample.

To appreciate the magnitude of this effect, it is instructive to compare our results to those found by researchers analyzing other stakeholder actions. For instance, in their study of the relationship of protests to stock price returns, King and Soule (2007) found that targeted firms suffered a $-1.03 \%$ return during the 26 -day window. This suggests that the market views civil litigation in general, and ATS lawsuits in particular, as a much more serious economic threat to firms than protests - a fact that may help explain why firms targeted by lawsuits are more likely to offer concessions than those targeted with other stakeholder tactics (e.g., Eesley \& Lenox, 2006).

\section{Regression Analysis of CAR}

To determine whether a relationship exists between our independent variables and abnormal returns and the magnitude of any such relationship, we performed an OLS regression using the 26-day CAR as our dependent variable, following the method used by King and Soule (2007). Regression results are shown in Table 5 . 
TABLE 5: Regression Coefficients

\begin{tabular}{|c|c|c|c|c|c|c|}
\hline \multicolumn{7}{|c|}{ Regression Coefficients $^{a}$} \\
\hline \multirow{2}{*}{\multicolumn{2}{|c|}{ Model }} & \multicolumn{2}{|c|}{ Unstandardized Coefficients } & \multirow{2}{*}{$\begin{array}{c}\text { Standardized } \\
\text { Coefficients } \\
\text { Beta }\end{array}$} & \multirow[b]{2}{*}{$\mathrm{t}$} & \multirow[b]{2}{*}{ Sig. } \\
\hline & & B & Std. Error & & & \\
\hline \multirow[t]{2}{*}{1} & (Constant) & -4.027 & 1.874 & & -2.149 & .034 \\
\hline & Size & -1.559 & 2.320 & -.071 & -.672 & .503 \\
\hline \multirow[t]{7}{*}{2} & (Constant) & 3.098 & 3.168 & & .978 & .331 \\
\hline & Size & -3.763 & 2.625 & -.171 & -1.434 & .155 \\
\hline & ${ }^{*}$ Extractive & -4.450 & 2.646 & -.195 & -1.682 & $.096^{\star *}$ \\
\hline & *NGO & -2.167 & 2.534 & -.094 & -.855 & .395 \\
\hline & ${ }^{*} \mathrm{CSR}$ & 2.013 & 2.945 & .076 & .684 & .496 \\
\hline & *Labor & -6.257 & 2.657 & -.281 & -2.355 & $.021^{* *}$ \\
\hline & *Mulltidefs & -1.854 & 2.314 & -.087 & -.801 & .425 \\
\hline
\end{tabular}

a. Dependent Variable: 26 Day CAR with company vector

b. $\quad *$ sign in predicted direction

c. ${ }^{* *}=$ statistically significant at $p<.05$ based upon the appropriate directional test of significance

As we can see, the coefficient for "Labor" is negative and significant $(p<.05)$, suggesting that ATS lawsuits involving allegations of labor rights abuses are viewed by investors as particularly serious threats to the corporate defendant's economic prospects. This finding is consistent with past empirical research showing that protests targeting labor issues generated lower than expected stock price returns than those targeting other issues (King \& Soule, 2007). The coefficient for "Extractive" is also negative and significant $(\mathrm{p}<.05)$, suggesting that investors also view ATS litigation involving large mining and construction firms as a considerable economic threat. This finding is consistent with past research showing that firms in industries with reputations for 
environmentally-damaging operations, including mining, energy, and chemicals, experienced proportionately greater market declines in the aftermath of the 1999 WTO protests in Seattle than firms with reputations for responsible environmental practices (Epstein \& Schnietz, 2002). None of the other predictor variables are significant, although all of the signs are in the expected direction.

\section{Discussion}

Our findings suggest that the announcement of civil lawsuits against MNEs for alleged complicity in human rights abuses and other misconduct overseas has a substantial negative relationship to the target firm's share price. Moreover, we find cases alleging violations of internationally recognized labor standards are associated with a significant loss of shareholder wealth, as are cases targeting extractive companies. These findings have important implications for multinational firms with existing operations in developing countries, as well as those considering such investments. For firms with existing investments, it suggests that they can no longer turn a blind eye to serious human rights abuses committed by government security forces, paramilitary groups, or private security forces, since they may be held liable for abetting these abuses in a U.S. federal court and have to pay a steep financial price.

But it is not only the conduct of foreign governments and security forces that need to be more closely monitored; MNEs increasingly must answer for the activities of joint venture and consortium partners as well as other businesses in their supply chains and certify that the final products sold under their brand names were produced in a humane and ethical way. This is a considerable challenge given the growing complexity of supply 
chains in many industries, which may include overseas suppliers, agents, contractors, and other third parties. As Dovey (2009) observes, a key question for corporate managers is to determine how far down the supply chain their responsibility goes, and then take steps to enhance due diligence. In some cases this may involve terminating relationships with contractors, as Levi Strauss did in Saipan after discovering that the contractor imposed forced labor on some of its Chinese workers and failed to honor minimum wage legislation (Schoen et al., 2005). In others it may involve coming up with creative solutions to preserve valuable sourcing relationships, as Levi's did in Bangladesh after it found out that its local contractor employed workers under the age of 14 in its factories, in violation of company guidelines, but permissible under local law. In this case the company chose to pay the workers while they attended school and then give them fulltime jobs upon turning 14 (Schoen et al., 2005).

Similarly, our research suggests that the "enclave model" of political risk management (Kapstein, 2006) favored over the years by extractive companies and other firms doing business in conflict zones may no longer be viable. After all, this model, which is premised on minimizing contact with local communities and other stakeholder groups through heavy investments in perimeter security and close operational relationships with local militaries, may invite unwanted attention from activist and antigovernment groups. These groups may specifically target the MNE to make a political statement or provoke it into a disproportionate response, which can then serve as the basis for a lawsuit.

A much better approach, in many cases, may be the "engagement model" (Kapstein, 2006), which involves looking for ways to embed the firm within the host 
society, typically by forging close relationships with community groups and investing in schools, clinics, roads, water wells, and other infrastructure. Such an approach may enhance the firm's legitimacy and help it maintain its "social license" to operate (Gunningham, Kagan, \& Thornton, 2004). Firms adopting an engagement strategy especially in the context of violent conflict -- may also gain a sustainable, long term-term competitive advantage (Oetzel, Getz, \& Ladek, 2007). As former Talisman Energy CEO Jim Buckee recently remarked: "If you are seen as a welcome presence on the ground, then you are in a much better position than if you are hated" (Campbell, 2011).

Our research also suggests that firms with existing operations in high-risk developing countries ought to look for ways to reduce their vulnerability to ATS lawsuits. Possibilities run the gamut from adopting human rights policies, voluntary codes of conduct, joining multilateral stakeholder engagement initiatives such as the UN Global Compact (Janney, Dess, \& Forlani, 2009), and entering into multi-stakeholder partnerships with NGOs, academics, and other civil society groups (Dahan et al., 2010). A particularly innovative partnership initiative was launched in 2007 following an ATS lawsuit against Yahoo! Inc. for providing private user information to the Chinese government, which then used it to arrest a political dissident. Formed by technology industry leaders including Yahoo!, Google, and Microsoft, and NGOs, academics, and investors, the Global Network Initiative provides guidance to firms on how to protect freedom of expression and the right to privacy in the face of demands from authoritarian governments (Dovey, 2009).

Other noteworthy multi-stakeholder partnership programs include the Extractive Industries Transparency Initiative, which brings together governments, firms, NGOs, and 
other stakeholder groups to address the issue of transparency in company payments to foreign governments for natural resource projects, and the Voluntary Principles on Human Rights and Security, a set of principles developed by extractive firms, governments, and NGOs to provide guidance on how to balance the need for the security and safety of employees and contractors with human rights obligations (Dovey, 2009). As management research on multi-stakeholder partnerships suggests, participation in these alliances can help enhance firm legitimacy and reduce risks while serving as a source of creativity and innovation that lead to new business opportunities (Hart \& Sharma, 2004; Yaziji, 2004).

For firms that are contemplating major investments in developing countries, particularly those with weak institutions, social and ethnic cleavages, or a history of human rights abuses, our research suggests that they should think twice. Some potentially profitable opportunities may be so fraught with social, legal, and reputational risk that they do not merit the investment. If a decision is made to proceed, firms should begin by conducting detailed risk assessments that go beyond the conventional analyses of political threats, including the possibility of nationalization by host governments or of kidnapping, extortion, and intimidation of personnel by criminal elements. They must also examine the potential social and environmental impact their operations may have on a broader range of stakeholders, the potential grievances these projects might engender, and the possibility that these grievance might resonate with activists and investors both domestically and abroad. As Drimmer (2010) observes, in conducting these risk assessments, investors should seek input for a wide variety of parties, including 
community leaders, government officials, and NGOs, and then craft a compliance program that addresses these concerns.

Knowing that their firms' share prices are vulnerable to ATS lawsuits and the cloud of impropriety that accompany them, managers have an incentive to try to resolve these disputes proactively, before they result in litigation. Thus, from a corporate strategy standpoint, it would seem to make sense for firms facing the prospect of ATS litigation to reach out and initiate a dialogue with external stakeholder groups that could result in an out-of-court resolution. Such advice runs counter to that offered by Koku et al. (2001), who argued that firms should litigate lawsuits brought by individuals (including ATS cases, presumably), while settling those brought by other corporations, owing to the greater likelihood of losing in court to another corporation. While we acknowledge that defendant firms are likely to prevail in ATS cases that make it to trial (based on the small number of cases that have made it that far in the legal process), the victory might be a Pyrrhic one, given the hefty legal costs and damaging media attention that accompany such lawsuits. To this list of negative consequences we can now add the likelihood of a substantial loss of shareholder wealth in the days leading up to, and following, the filing of the lawsuit.

The idea that firms should settle such cases regardless of their merit raises the issue of moral hazard. If NGOs and other stakeholder groups conclude that they can easily win large settlements from corporations by initiating legal action, firms may quickly become inundated with a wave of new cases. However, this possibility is tempered by the reality that NGOs typically have limited resources and that mounting an ATS case is a costly endeavor that requires significant time and legal expertise. 
Moreover, recent court decisions have raised the bar in terms of what type of evidence is required from plaintiffs before a case is allowed to proceed beyond the pleading stage (Dunst, 2009). Thus, we do not foresee an exponential rise in ATS litigation in the coming years - although a steady increase is possible.

\section{Limitations}

This research enhances our understanding of the relationship between anticorporate civil litigation and target firm stock price reaction, thereby filling a gap in the empirical literature on stakeholder challenges to multinational firms. However, our study has several limitations. First, the constraints of our data and time period limit the scope of validity beyond the specific circumstance that is the subject of our analysis. Moreover, the construct validity of some of our measures could be questioned. For instance, while we believe that inclusion in the Calvert Social Index is a reasonable proxy for "Reputation for CSR," firms interact with society in a variety of different and complex ways, and it is possible that particular companies included in the list are viewed unfavorably by certain stakeholder groups, while other firms generally viewed as exemplary corporate citizens were omitted.

\section{Future Research}

Future scholars should analyze the extent to which the declines in shareholder wealth experienced by firms targeted by ATS lawsuits is a temporary phenomena, or more long lasting in nature, and whether subsequent lawsuits against a company have a similar effect on shareholder wealth. Research by Koku et al. (2001) suggests that firms 
that are subject to repeated lawsuits may become "judgment proof," in the sense that investors do not react in the same way to the announcement of new litigation as they did in the past, having already factored the probability of future lawsuits into the current share price.

The filing of the initial lawsuit is by no means the only significant event in the litigation life cycle. The market might view subsequent events including judgments on motions to dismiss, the filing of appeals, reversals by higher courts of lower court decisions, settlements, trials, and verdicts as equally or more significant. Thus, discerning whether there is a systematic pattern in the market reaction to news of such events is another important task for future research. Additionally, scholars should examine whether and how human-rights related litigation filed in U.S. state courts under statutes such as the Torture Victims Protection Act (TVPA) and the Racketeer Influenced and Corrupt Practices Act (RICO), as well as in foreign courts, is related to shareholder wealth, given the trend of plaintiffs filing transnational tort cases similar in substance to ATS cases outside the federal court system. ${ }^{38}$

Finally, future researchers might also examine the extent to which a corporation's stock price is related to the amount of media attention the lawsuit garners, the jurisdiction in which it is filed, and whether the lawsuit is part of a larger stakeholder campaign involving boycotts, protests, or shareholder resolutions. These questions provide a rich

\footnotetext{
${ }^{38}$ Examples of human rights-related cases filed in state rather than federal courts include those brought by banana workers on plantations in Nicaragua and elsewhere against Dole Foods, Dow Chemical, Shell Oil, and Occidental Petroleum for exposure to the pesticide DBCP. Occidental Petroleum has also been sued in a California state court by Peruvian plaintiffs for allegedly contaminating land and rivers in the Amazon region (Carijano v. Occidental Petroleum). An example of a human rights case filed in a foreign court is the one against Trafigura, a multinational oil-trading company, for allegedly dumping toxic oil off the coast of the Ivory Coast (Drimmer, 2010).
} 
research agenda for future scholarly inquiry into the relationship between stakeholderinitiated civil litigation and corporate financial performance. 
Essay III: Is It Who They Are or What They Do? Understanding the Factors that Predict Extractive Firm Vulnerability to Secondary Stakeholder-Initiated Human Rights

Litigation

\section{Abstract and Introduction}

Organizational researchers have recently examined the efforts of activist groups to influence corporate policies and practices through coercive tactics. Yet the issue of why certain firms are targeted for anti-corporate campaigns while others escape scrutiny has not yet been fully explored. Drawing upon social movement and social identity theories, we developed and tested a set of hypotheses on how stakeholder groups select their targets for human rights-related civil lawsuits under the U.S. Alien Tort Statute, a law that gives U.S. federal courts extraterritorial jurisdiction for cases involving allegations of serious offenses committed against foreign citizens. We found support for the idea that multinational targets are selected based on both interest and identity factors. Conclusions and implications for practice are drawn.

Organizational researchers have recently taken an interest in the phenomena of private politics (Baron, 2003), whereby activist groups seek to change corporate practices by directly targeting firms with coercive tactics, rather than exerting influence indirectly via appeals to the government (King \& Soule, 2007; Reid \& Toffel, 2009). ${ }^{39}$ While anticorporate activism has a long history in the United States, dating back at least to the Boston Tea Party (King, 2009), it appears to have taken on new vigor in recent decades,

\footnotetext{
${ }^{39}$ Appeals to the government typically include lobbying legislators and regulators and seeking judicial interpretations that institutionalize new and more favorable norms (Reid \& Toffel, 2009).
} 
spurred by the growth of non-governmental organizations (NGOs) (Yaziji \& Doh, 2009; Doh \& Teegen, 2003). Defined as social, cultural, legal, and environmental advocacy and/or operational groups that have goals that are primarily non-commercial (Kourula \& Laasonen, 2009), NGOs have established themselves as important agents of political and social change, championing issues ranging from animal welfare to climate change (Lyon, 2010). NGOs have raised awareness of ethical issues in global supply chains, spearheaded monitoring efforts of overseas factories, and promoted private certification schemes that encourage firms to adopt sustainable business practices (Conroy, 2007; O'Rourke, 2005). With more than 30,000 NGOs operating internationally, one-tenth of these drawing membership from three or more countries (Vogel, 2008), NGOs have considerable global reach. NGOs have grown in stature and influence in recent years and are now seen by some as having supplanted the role of host governments in the historic business-government bargaining relationship (Yaziji \& Doh, 2009).

Related to the growth of NGOs has been the spread of social movements, which have been defined as "collectivities acting with some degree of organization and continuity outside of institutional channels for the purpose of seeking or resisting change in some extant system of authority (Soule, 2009)." Together, NGOs and social movements, which often share similar characteristics and overlapping membership (Davis \& Zald, 2005), have helped to fill a "governance gap" caused by the decline in power of national governments and organized labor, coupled with the growing clout of "footloose" multinational enterprises (MNEs) (Soule, 2009; King \& Pearce, 2010). 
Using a variety of coercive tactics, from boycotts to shareholder (proxy) resolutions, ${ }^{40}$ NGOs and social movements pressure companies to meet their demands. Some of these tactics, such as civil lawsuits, impose a direct financial obligation on the target firm in the form of legal and public relations expenses (Lenox \& Eesley, 2009). Others, like boycotts and protests, may affect consumption patterns and corporate share price - particularly if they generate extensive media coverage (King \& Soule, 2007; King, 2008; Martin \& Kracher, 2008). All may inflict serious reputational harm, making it more difficult for the firm to attract and retain employees, suppliers, and investors, while diverting managerial attention away from more pressing strategic and operational concerns (Vogel, 2005; Yaziji \& Doh, 2009). ${ }^{41}$

Management and organization researchers seeking to understand the interplay between activist groups and corporations have recently employed stakeholder theory (Freeman, 1984) as a theoretical lens (Laplume, Sonpar, \& Litz, 2008). Stakeholder theory accords NGOs and social movements the status of "secondary stakeholders," which, unlike primary stakeholders (e.g., shareholders, employees, suppliers, and creditors), are not vital to organizational survival (Clarkson, 1995). As such, these groups should attract little managerial attention (Mitchell et al., 1997).

Yet we know that mangers not only pay attention to these secondary stakeholders, they sometimes meet their demands. For instance, PepsiCo, Disney, Levi Strauss, and Apple Computer, among others, bowed to pressure from the student-based Free Burma

\footnotetext{
${ }^{40}$ Proxy resolutions are often initiated by activists who specifically buy enough shares to initiate a vote on these resolutions at annual shareholder meetings (Soule, 2009).

${ }^{41}$ In addition to using coercive tactics to inflict harm upon firms, NGOs and social movements seek to create new markets for sustainable products and services, including "sweat-free" garments and fair trade coffee (O’Rourke, 2005).
} 
Coalition in the 1990s and divested from Burma (Myanmar) (Spar \& LaMure, 2003); Nike capitulated to the United Students Against Sweatshops and affiliated pressure groups and demanded that foreign suppliers improve working conditions within their factories (Soule, 2009); Starkist conceded to the Earth Island Institute's (EII) demands that it implement dolphin-safe fishing practices throughout its foreign supply chain (Frooman, 1999); and grocery chain Trader Joe's agreed under pressure from Greenpeace to remove genetically modified products from its shelves (Frooman \& Murrell, 2005). Meanwhile, in the early 1990s, a coalition of environmental groups that included Greenpeace and the Rainforest Action Network succeeded in getting the forest products industry to establish the Forest Stewardship Council, a private regulatory body that put forth stringent industry-wide deforestation standards (Bartley, 2007).

While there is growing recognition amongst organization researchers that secondary stakeholder groups can and do exert meaningful influence vis-à-vis firms and markets (de Bakker \& den Hond, 2008; King \& Pearce, 2010), the question of why particular firms become targets of activist pressure while others fly below the radar has only received limited attention in the management literature (Whetten, Rands, \& Godfrey, 2002).

Rowley and Moldoveneau (2003) propose that anti-corporate activist groups are driven by two distinct sets of factors: interest-based motivations and identity-based motivations. The former pertain to issues these groups hold to be important, including conservation, social justice, and non-discrimination in the workplace. Identity-based factors, by contrast, relate to the organizational imperative to foster solidarity and collective identity. If stakeholder groups are driven primarily by interest-based 
motivations, they might be expected to target companies in industries that generate negative externalities such as air and water pollution, as well as specific firms perceived to be particularly negligent on social, environmental, and workplace issues. Conversely, if driven primarily by identity-based motivations, these groups might be expected to target companies for reasons unrelated to their industry or social performance. Indeed, such groups might choose to target highly visible and socially progressive firms to generate publicity and mobilize support from members and donors (Rowley \& Moldoveneau, 2003).

A recent review of the empirical literature suggests that "both repeated wrongdoers and larger and more visible firms are at a greater risk of stakeholder scrutiny," thus lending support for both interest-based and identity-based explanations (de Bakker \& den Hond, 2008). Whether this holds true for stakeholder-initiated civil lawsuits, however, remains an unanswered question. Legal challenges differ from other stakeholder tactics in important ways. They are typically more expensive to mount than proxy resolutions, boycotts, or protests, more difficult to organize and execute, and require specialized legal knowledge that few NGOs possess (Holzmeyer, 2009). Moreover, litigation-based campaigns require broader and denser support networks than do other types of stakeholder campaigns, particularly those involving allegations of overseas crimes, since attorneys must often rely on intermediaries to gain access to local communities to gather evidence (Davis, 2008; Risse, Ropp, \& Sikkink, 1999). Finally, since successful legal campaigns require significant resource commitments over extended periods of time, plaintiffs hoping to prevail must consider the resources their prospective target might be able to marshal to defeat the challenge - a strategic calculation that stakeholder groups 
employing alternative tactics like boycotts or protests may not need to make (Holzmeyer, 2009).

Thus, from the standpoint of the NGOs considering potential corporate targets for their legal campaigns, do interest or identity factors take precedence? Or, stated differently, are targeting decisions based on who they are or what they do? We study this question by examining lawsuits filed by NGOs in recent years against natural resources firms under the Alien Tort Statute (ATS), a controversial 1789 law that allows foreign citizens to sue private individuals and corporations in U.S. federal courts for specific international human rights violations. ${ }^{42}$ Since a landmark 1996 case against Unocal for alleged complicity in human rights violations committed by the Burmese military in furtherance of a $\$ 1.2$ billion natural gas pipeline project, ${ }^{43}$ the ATS has been used to sue some of the world's largest MNEs, including Citigroup, Dow Chemical, General Motors, Exxon Mobil, Chiquita, Bridgestone, Coca-Cola, IBM, and Wal-Mart (Gallagher, 2010). These charges range from aiding repressive governments in their efforts to crack down on political dissidents (Yahoo, Cisco Systems) to conducting non-consensual clinical trials on children (Pfizer) (Drimmer, 2010).

Although firms from a wide variety of industries, including chemicals, pharmaceuticals, financial services, and agriculture, and food and beverages, have been

\footnotetext{
${ }^{42}$ The ATS, which is part of the Judiciary Act of 1789, allows individual plaintiffs to sue for violations of the "law of nations." While legal scholars dispute which specific crimes constitute violations of this law, there is general agreement that the list includes extrajudicial killing, rape, genocide, slavery, and torture (Drimmer, 2010).

${ }^{43}$ The Unocal case was filed in 1996 by NGOs Earth Rights International and the Center for Constitutional Rights on behalf of Burmese villagers who claim they were beaten, raped, tortured, and conscripted into labor by the Burmese military as part of the Yadana natural gas pipeline project jointly owned by Unocal, Total of France, and the Burmese government (Davis, 2008).
} 
sued under ATS, those involved in natural resource extraction have been the most frequent targets (Drimmer, 2010). This may be because extractive firms typically have limited choices about where they can invest -- they must go where the resources are. Since these resources are often buried beneath the soil in countries run by authoritarian regimes or torn by internal conflict, MNEs involved in natural resource extraction may be particularly vulnerable to claims of complicity in human rights abuses (Kaeb, 2008).

But even amongst extractive firms, not all players appear equally exposed to ATS litigation. Of the U.S.'s three largest privately-owned oil and gas companies (supermajors), two - Exxon Mobil and Chevron - have been targeted with ATS lawsuits, and both have been sued multiple times. Yet the other supermajor, ConocoPhillips, which also operates in countries prone to instability and violence, has escaped ATS litigation. What explains this anomaly? Likewise, what explains the fact that Occidental Petroleum, a company with assets of $\$ 52$ billion, has been sued four times under ATS, while Marathon Oil, a company of equivalent size (in assets) and with operations in some of the same countries has been given a pass?

Given that legal analysts expect a steady drumbeat of ATS cases against MNEs and their senior executives for years to come (Drimmer, 2010), it is important for managers to understand the factors that may make their firms vulnerable to this type of activist pressure. Such knowledge may allow them to craft effective risk mitigation strategies that safeguard corporate reputations and preserve shareholder wealth. 
XIV. Theory and Literature Review

In recent years a growing, multidisciplinary body of scholarly research has emerged that examines the ways in which activist groups interact with firms and markets (Kourula \& Laasonen, 2009; Doh \& Teegen, 2003; Rao, 2009). Much of this literature uses stakeholder theory (Freeman, 1984) as a conceptual lens. A stakeholder is "any group or individual who can affect or is affected by the achievement of the organization's objectives (Freeman, 1984: 46)." In contrast to the shareholder perspective, which views profit maximization as the sole objective of the corporation (Friedman, 1962), stakeholder theory views the economic goals of the corporation to be less important than organizational survival, which can be enhanced by cultivating strong relationships with a wide array of groups with a stake in the corporation, including employees, customers, suppliers, creditors, and communities, as well as shareholders (Soule, 2009).

Stakeholder theory accords NGOs and social movements the status of secondary stakeholders (Clarkson, 1995). Unlike the primary stakeholders of the company (e.g., shareholders, workers, suppliers, and creditors), secondary stakeholders have no contractual bond to the firms they seek to influence, little resource leverage, and are not necessary for survival (Clarkson, 1995; Eesley \& Lenox, 2006). As such, theory suggests they should attract little attention from managers and have limited sway over corporate policy (de Bakker \& den Hond, 2008). Mitchell and colleagues (1997) claim that managers are most likely to pay attention to the demands of those stakeholders with power, legitimacy, and urgency. ${ }^{44}$ Empirical research supports the notion that managers

\footnotetext{
${ }^{44}$ According to Mitchell and colleagues (1997), a stakeholder has power to the extent that it "has or can gain access to coercive, utilitarian, or normative means to impose its will in the relationship." Legitimacy is "a generalized perception or assumption that the actions of an entity are desirable, proper, or appropriate within some socially constructed system of norms, values,
} 
tend to resist influence efforts by secondary stakeholders, while being more receptive to overtures from primary stakeholders (Agle, Mitchell, \& Sonnenfeld, 1999; David et al., 2007; Eesley \& Lenox, 2006).

But, as previously mentioned, it is clear that secondary stakeholder groups do sometimes influence corporate policies and practices - in ways both subtle and profound. How, then, do secondary stakeholder groups select the corporate targets they wish to influence? As de Bakker and den Hond (2008) observe, few management researchers have analyzed this question. Nor have social movement scholars, who have traditionally focused their attention on influence efforts aimed at states, given this question due attention (Soule, 2009). As Bartley and Child (2007) point out, the constitution of corporate targets for social movement pressure is a topic "ripe for sociological analysis."

Perhaps the most compelling explanation of stakeholder mobilization and targeting has been put forth by Rowley and Moldoveanu (2003). Building upon social movement and social identity theories (Ashforth \& Kreiner, 1999; Fireman \& Gamson, 1979), the authors argue that both interests and identities influence activist groups in their decisions to take action against firms. The case for interest-based motivations is anchored in rational choice theory (Olson, 1965). It suggests that activist groups act to advance or protect their particular interests - especially when they perceive these interests to be under threat (Savage, Nix, Whitehead, \& Blair, 1991). Thus, an environmental NGO (ENGO) might be expected to target a firm that is a notorious polluter, whereas a labor rights advocacy NGO might confront a firm renowned for using sweatshop labor.

beliefs, and definitions." And urgency "exists only when two conditions are met: 1) when a relationship or claim is of a time-sensitive nature and 2) when that relationship or claim is important or critical to the stakeholder." 
Rowley and Moldoveanu (2003) accept this logic, but contend that stakeholder groups also take actions to strengthen their internal solidarity and collective identity, irrespective of whether these actions advance their organization's strategic goals. Thus, a stakeholder group might undertake an action with little realistic chance of success (e.g., a boycott) against a firm that is widely admired (e.g., Starbucks), simply because the action affirms the group's social identity. A stakeholder group might also initiate action against a target firm primarily to differentiate itself from other stakeholder groups that share similar goals, thereby satisfying its desire to establish a unique identity (Rowley \& Moldoveanu, 2003). In short, from an identity-based perspective, collective action is an end in itself, rather than a means to achieve more rational interests (Larana, Johnston, \& Gusfield, 1994).

Several researchers have attempted to subject these ideas to an empirical test. Rehbein, Waddock, \& Graves (2004), for instance, used the Rowley \& Moldoveanu's (2003) theory as the framework for their study of the targeting decisions of religious, environmental, and pro-labor activist groups filing proxy resolutions at shareholder meetings. They found that these shareholder activists tend to target companies with problematic products and poor environmental and community-related practices, thus providing support for interest-based explanations. But they also found that activists target large and highly visible firms, providing support for identity-based explanations.

Similarly, Bartley and Child (2007) found that identity-based characteristics such as firm image, reputation, and size influence the targeting decisions of anti-sweatshop activists, as do interest-based factors, including the extent to which a firm has globalized its production through contractual agreements with foreign garment producers. Lenox 
and Eesley (2009) reached similar conclusions in their study of ENGO campaigns against corporate targets. They found the likelihood of being targeted with lawsuits, protests, boycotts, letter-writing campaigns, and proxy votes to be related to both "issue factors" (i.e., environmental performance) and "identity factors" (i.e., size and visibility).

Taking a different methodological approach, Hendry (2006), who conducted interviews with leaders of ENGOs such as Greenpeace and Environmental Defense, found that activists weighed factors such as the firm's environmental impact, as well as its size and potential influence on others in its organizational field, when making targeting decisions. In short, the available evidence, empirical and anecdotal, suggests that both interest and identity factors influence the targeting decisions of NGOs.

Although it has yet to be examined, there is reason to believe that both interest and identity-based motivations are also salient to NGOs that file ATS litigation. After all, the small cadre of NGOs that initiate these lawsuits (by serving as legal counsel to foreign plaintiffs) are publicly committed to pursuing social justice and advancing international human rights norms. Targeting firms that condone or facilitate crimes like murder, torture, and forced labor, would thus appear to serve their organizational interests.

Moreover, by "naming and shaming" firms that allegedly violate human and workers' rights and despoil the environment, these NGOs may feel they are sending a signal to other firms within the target firm's industry, as well as the broader organizational field, that they should think carefully about their social and environmental footprint (Fielding, 2008). ${ }^{45}$

\footnotetext{
${ }^{45}$ A litigator with the NGO Earth Rights International recently suggested as much: "I think that (the) Unocal (case) and these other cases have caught enough attention that any corporate counsel
} 
Similarly, NGOs that initiate ATS litigation might calculate that their actions could cause government regulators to increase their scrutiny of the target firm, thereby prompting directors concerned about the firm's reputation to pressure managers to improve their social and environmental practices (Williams \& Conley, 2007). Finally, NGOs that initiate ATS cases might believe that even if their efforts do not bear immediate fruit, they are tilling the soil for future social change, thereby serving as "transnational norm entrepreneurs" (Koh, 1998).

Also consistent with interest-based explanations is the idea that NGOs might be motivated to file ATS lawsuits to solidify relationships with like-minded stakeholder groups and gain access to new resource streams (Rowley \& Moldoveanu, 2003). After all, preparing an ATS case is an expensive and time-consuming process that requires extensive research and evidence-gathering, both at home and abroad (Davis, 2008). By leveraging relationships with other advocacy groups, as well as public interest attorneys, and corporate attorneys offering pro-bono services, NGOs may be able to increase the number of cases they take on, while enhancing their odds of success in court (Davis, 2008; Risse, Ropp, \& Sikkink, 1999).

And while it is not clear that "relationship building" has been the explicit objective of any past ATS filings, it certainly has been an important outcome. The landmark Doe vs. Unocal litigation is a case in point. Filed by the Center for Constitutional Rights (CCR) and Earth Rights International (ERI), the case helped galvanize the international human rights community and establish a tight network of NGOs and public interest attorneys with expertise in human rights litigation (Davis, worth his salary... is going to say wait a second you need to think about this. If this happens you're going to get sued" (Davis, 2008). 
2008). The Unocal case also enabled NGOs to tap new sources of finance: ERI was founded with seed money from the Echoing Green foundation based on the promise of the case (Holzmeyer, 2009). Meanwhile, the funds the plaintiffs received from the settlement - estimated at between $\$ 30$ and $\$ 60$ million (Kropf, 2010) -- provided substantial resources to pursue future litigation.

But interest-based explanations for NGO-initiated legal action do not appear to tell the whole story. After all, as previously mentioned, the costs of preparing these lawsuits in terms of time, energy, and resources are substantial, while odds of prevailing in court are exceedingly small. Indeed, of the more than 100 corporate ATS cases that have been filed to date, most have been dismissed by federal courts on jurisdictional grounds, ${ }^{46}$ a few have been settled, ${ }^{47}$ and the two that have made it to trial have resulted in verdicts for the defendants (Drimmer, 2010). ${ }^{48}$ The prospects for success in ATS litigation, in the form of a trial victory or settlement, are in fact so dim that the act of filing such lawsuits -- like that of filing proxy resolutions -- may be akin to pursuing a

\footnotetext{
${ }^{46}$ Under the doctrine of forum non conveniens, the courts may dismiss cases if a more appropriate alternative forum exists.

${ }^{47}$ The list of corporate ATS cases that have been settled in recent years includes the so-called "Nazi gold" lawsuits of the late 1990s, which secured $\$ 1.25$ billion in compensation from Swiss banks for victims of the Holocaust and the case against Unocal in Burma (reportedly between \$30 and $\$ 60$ million). Other major settlements include those involving U.S. apparel and retail companies for allegations related to sweatshop labor in Saipan (\$20 million), Royal Dutch Shell for alleged human rights violations in the Niger Delta (\$15.5 million), and Yahoo! Inc. for divulging private information on political dissidents to the Chinese government (undisclosed amount) (Goldhaber, 2010).

${ }^{48}$ One of these cases (Bowoto v. Chevron) alleged that Chevron was complicit in the Nigerian military's violent crackdown against unarmed protesters at one of the company's offshore oil platforms. The other case (Romero v. Drummond Co.) was based on accusations that the Drummond Company conspired with Colombian paramilitary organizations to murder union leaders at one of its coal mines (Kropf, 2010).
} 
"lost cause" (Rao, 2001) ${ }^{49}$ Given the high costs associated with filing ATS cases and their low success rates, NGOs interested in changing corporate practices in the developing world would seem to be better served by engaging in other types of advocacy. ${ }^{50}$

If interest-based motivations do not fully explain why NGOs choose to target firms with ATS litigation, it may be because other motivations are at play, namely the desire to affirm and solidify the group's identity (Rowley \& Moldoveanu, 2003). There are numerous ways in which the act of filing civil litigation against a corporation could satisfy an NGO's identity needs, even if the litigation is ultimately unsuccessful. For instance, it might mobilize support from members and grass-roots activists that like the idea of confronting powerful corporate interests in a public forum (McCann, 1994). Targeting large, prominent, profitable, and well-reputed corporations with allegations of grave misconduct might also be expected to draw publicity, thereby energizing supporters and renewing their emotional investment in the NGO (Melucci, 1995).

Filing ATS cases against corporations might also enable NGOs to distinguish themselves from other organizations pursuing similar agendas, thereby enhancing their appeal to donors. After all, there is a plethora of advocacy groups committed to progressive causes, and the competition for donations is intense (Weisbrod, 1998). Just as firms find it important to distinguish themselves from their rivals when appealing to

\footnotetext{
${ }^{49}$ Rao (2001) contends that individuals, acting as "gadflies," submit proxy resolutions and attend shareholder meetings to protest firm practices, despite the fact that few other shareholders share their concerns, and with the knowledge that their activities will most likely have little or no impact on firm behavior.

${ }^{50}$ As Holzmeyer (2009) observes, two prominent schools of legal thought, Legal Realism and Critical Legal Studies (CLS), regard litigation as having little potential to promote meaningful social reform and that activists in most cases would be better served by adopting non-legal strategies.
} 
customers and investors, so too must NGOs (Lowery \& Brasher, 2004). Evidence that competitive differentiation takes place amongst NGOs involved in human rights litigation abounds. For instance, the International Labor Rights Fund (ILRF), a Washington, D.C.based human and labor rights advocacy group that has filed ATS cases against numerous MNEs including Coca-Cola, Wal-Mart, Drummond Co., and Chiquita, boasts in a recent annual report that it is the sole human rights and labor NGO to have utilized both ATS litigation and more conventional tactics, such as boycotts, as part of its advocacy efforts (Holzmeyer, 2009).

In sum, there are reasons to expect that both interest and identity factors may influence the targeting decisions of NGOs that file ATS litigation against corporations. We next develop and test a series of hypotheses based on these expectations.

XV. Hypotheses

In this section we put forth a series of hypotheses about the factors we believe may influence the targeting decisions of NGOs filing ATS lawsuits against extractive firms. These hypotheses consider both interest-based and identity-based factors.

Interest-based Factors

1. Social Performance - Jones (1991) suggested that observers seeking to understand what motivates individuals to take action ought to consider the "moral intensity" of the issue at hand. A key element of moral intensity is the "magnitude of the consequences" 
associated with the focal issue. ${ }^{51}$ Issues that are perceived to threaten individual interests in a clear, direct, and profound way are more likely to stimulate action than those which pose a less obvious, immediate, or serious threat. While Jones developed his theory to explain individual action, Rowley and Berman (2000) have argued that the logic is also applicable to stakeholder groups. As such, we might presume that NGOs seeking to promote their interests and agendas would deploy their limited resources in an effort to change the behavior of the firms they perceive to most acutely threaten these interests -namely those generating the largest negative social and environmental impacts (i.e., the worst social performers).

In addition to pressuring these poor performers to change their ways, activists might calculate that suing the most egregious offenders could send a powerful signal to other firms with questionable labor and environmental practices or those considering investments in countries where human rights abuses are pervasive (Davis, 2008). Anecdotal evidence supports the idea that activist groups base their adversarial targeting decisions at least in part on the firm's past conduct. For instance, Hendry (2006) found that nearly three-fourths of ENGO leaders she interviewed cited the magnitude of the

${ }^{51}$ Other components of moral intensity include social consensus, probability of effect, temporal immediacy, proximity, and concentration of effect (Jones, 1991). 
consequences associated with a firm's behavior toward the natural environment (e.g., impacts on biodiversity, climate change, and human health) as critical factors in their targeting decisions. We therefore propose:

H1 - Firms with relatively poor social performance are more likely to be targeted with ATS lawsuits than firms with relatively good social performance. Identity-based Factors

2. Firm size - There are legitimate reasons why stakeholder groups would choose to target large firms with ATS lawsuits. After all, these firms are often market leaders in their industries and have high social prominence (Miles, 1987; Salancik, 1979; Suchman, 1995). Such firms may also have well-known brands. While such brands are often viewed as an asset for the firm, conveying information to consumers about the firm's corporate values and the quality and authenticity of its products and services (O'Rourke, 2005), they represent a liability from the perspective of the activist group that can be exploited through coercive tactics designed to damage these intangible assets (Conroy, 2007). Indeed, as Klein (1999) observes: "the more ambitious a company has been in branding the cultural landscape... the more likely it is to have generated a silent battalion of critics waiting to pounce.”

Targeting large, prominent firms may also help mobilize support from members and other organizations within the NGO's network (Rowley \& Berman, 2000). Amnesty International's recent campaign against Shell for its allegedly damaging business activities in the Niger Delta is a case in point. The NGO admits that it selected Shell as 
the target for the campaign - its largest ever against a single company - because it has a very well-known brand that is useful in mobilizing activists (Williamson, 2009). And targeting large, prominent firms may also assist NGO fundraising efforts, since donors tend to respond favorably to high-profile campaigns that attract media attention (Weisbrod, 1998).

In addition to the identity-enhancing benefits that may accrue to organizations from targeting large firms, such actions may also bring benefits to individuals within these organizations. Organization leaders, in particular, may experience enhanced recognition and respect as a result of high-profile campaigns against market leaders (David et al., 2007; Lenox \& Eesley, 2009). And while the probability of prevailing in a legal dispute against a large firm may be slim, the potential payoff, including sweeping changes to company and industry practices that impact an entire organizational field, may merit the investment (Hendry, 2006). And in the case of an ATS lawsuit, the payoff might be a lucrative financial settlement or a favorable jury verdict accompanied by millions of dollars in damages, providing NGOs with the resources to fund future cases. Based on this, we propose the following:

H2 - The larger the firm, the more likely it is to be targeted with an ATS lawsuit.

3. Reputation - In recent years management researchers have devoted increasing attention to the topic of corporate reputation, exploring its antecedents and outcomes (Lange, Lee, \& Dai, 2011; Rindova, Williamson, Petkova, \& Sever, 2005). Broadly defined as a perceptual representation of the firm's overall appeal to key stakeholders compared with 
leading rivals based on past actions (Roberts \& Dowling, 2002), corporate reputation is widely seen as having considerable economic value (Fombrun, 2001). Indeed, Lev (2001) estimates that "intangible factors," which include a firm's reputation, comprise up to fivesixths of the market capitalization of the S\&P 500 firms. In addition to being able to charge a premium for their products and services, highly-reputed firms may have an advantage over rivals in the competition talented workers, reliable suppliers, and low-cost investment capital (Fombrun \& Shanley, 1990; Fombrun, 1996; Turban \& Greening, 1997). A good reputation may also confer insurance-like benefits in the event of a crisis, cushioning the firm from potentially negative outcomes (Jones, Jones, \& Little, 2000; Schnietz \& Epstein, 2005; Godfrey, Merill, \& Hansen, 2009). In short, a good reputation in marketplace is a powerful intangible asset that may represent a source of competitive advantage for its owner (Hall, 1992; Roberts \& Dowling, 2002).

But research suggests that a firm's reputation may also be a source of vulnerability -- especially if it is perceived that the company has failed to live up to social expectations (King \& Pearce, 2010). Indeed, highlighting hypocrisies so as to "hoist the firm on its own petard" has become a key stratagem of anti-corporate campaigns (Bartley \& Child, 2007; Manheim, 2001; O'Rourke, 2005). Given the great lengths to which firms go to build their reputations through philanthropy and other corporate citizenship initiatives (Gardberg \& Fombrun, 2006), NGOs may calculate that managers concerned with safeguarding their firm's reputational assets might be willing to make concessions in the face of activist pressure that could jeopardize the value of these assets - a phenomena that Spar and LaMure (2003) refer to as "preemptive capitulation." Such concessions might include changes to policies identified as objectionable by activists or the settlement 
of lawsuits on generous terms. Stakeholder groups might also believe that targeting highly reputed firms would send a message to firms further down the status hierarchy (Bartley \& Child, 2007), while generating enhanced commitment from members and donors. Based on this logic we propose:

H3 - Firms with good reputations are more likely to be targeted with ATS lawsuits than firms with poor reputations.

4. Financial Performance - There are reasons to expect that activist groups considering potential corporate targets for ATS litigation might choose firms that have recently experienced weak financial performance. After all, theory suggests that the managers of financially troubled firms may be more sensitized to the concerns of external stakeholders, and more willing to accommodate them, fearing that further "bad news" could trigger even steeper declines in sales or market share, the loss of legitimacy, or enhanced external monitoring (King, 2008). But an alternative logic suggests that firms with weak financial performance may be unattractive targets for activist pressure. Such firms, after all, typically have less slack than firms with good financial performance (Cyert \& March, 1963), and thus fewer resources to make concessions. Indeed, financially distressed firms might be focused primarily on survival, and thus primarily attuned to the needs of primary stakeholders. Conversely, managers of firms with good financial performance may view concessions to secondary stakeholders in the form of changes to operating practices, the adoption of corporate social responsibility (CSR) initiatives, or payments to settle lawsuits as a type of insurance policy that could generate 
goodwill (Godfrey, 2005). Such concessions might also be viewed as a way to help bolster trust and legitimacy and buffer the firm from possible future activist attacks (Baron 2001; Baron \& Diermeier, 2007). Based on this latter logic, we propose:

H4 - The better a firm's financial performance, the more likely it is to be targeted with ATS lawsuits.

XVI. Methodology

\section{Data Collection Technique}

The sample for this study is drawn from multiple data sources. Information on all ATS lawsuits filed against MNEs involved in natural resource extraction and production between 1996 and 2010 was gathered using the LexisNexis and Westlaw legal databases. We selected 1996 as the start date for our study since the first major human rights-related corporate ATS lawsuit (Doe v. Unocal) was filed that year. Our legal research was supplemented by searching business news abstracts in Bloomberg Law, Lexis-Nexis, and ProQuest for articles about the filing of human rights-related civil lawsuits against extractive corporations published in the major international business press (e.g., The Wall Street Journal, The New York Times, and The Financial Times) and wire services (e.g., Bloomberg, Dow Jones, Reuters, and the Associated Press). Keywords searches were conducted using terms such as "alien tort," "civil litigation," "lawsuit," "human rights," and individual company names, obtaining information on ATS lawsuits involving 32 multinational corporate defendants. This was reduced to 14 cases after eliminating 
foreign-headquartered companies, privately owned firms, and firms that were sued by private law firms without NGO involvement. See Appendix B for a list of corporate defendants in ATS litigation and a brief synopsis of the cases.

Our final sample includes a variety of extractive firms, including those that explore for and process petroleum, natural gas, coal, and precious metals, as well as several that provide infrastructure and services for these endeavors. Represented in our sample are defendants in large class-action lawsuits with dozens of MNEs such as the South African Apartheid litigation (Khulamani v. Barclay's National Bank Ltd.), which seeks damages from multinational companies and banks that did business with Pretoria between 1948 and 1994, and cases with a single corporate defendant, such as Bowoto v. Chevron Corp., involving charges of complicity in a violent crackdown by the Nigerian military against unarmed protesters at an offshore oil platform. Our sample also includes several firms that had more than one ATS lawsuit filed against them during the time series, including Exxon Mobil (2), Chevron (2), and Occidental Petroleum (4).

In order to assess the likelihood of that a specific firm might be sued under ATS, we created a second (matching) database of privately-owned U.S. extractive firms that have not been sued under this statute. This control sample was culled from the 2010 Forbes Global list of the world's 2,000 largest publicly owned corporations by performing searches using the industry filters "Oil and Gas Operations," "Diversified Metals and Mining," "Aluminum," and "Construction Services." These searches yielded 40 U.S. firms. We narrowed the list to 36 firms by eliminating companies that did not have five consecutive years of financial or KLD data (Hillman, Shropshire, \& Cannella, 2006). We then examined the two digit Standard Industrial Codes (SIC) codes of the 
firms on the two lists to assure that they were similar and proportional in composition. The SIC codes of the sample firms are as follows: 10 - Metal mining; 12 - Coal mining; 13 - Oil and gas extraction; 16 - Heavy construction, except building; and 49 - Electric, gas, and sanitary services. See Appendix B for the list of firms in our comparison sample.

Our combined sample (sued and not sued firms) consists of 50 companies, with 2010 market capitalizations ranging from $\$ 3.5$ billion (Tesoro) to $\$ 407$ billion (Exxon Mobil). The average market cap is roughly $\$ 35$ billion. In terms of assets, the sample firms range from $\$ 1.7$ billion (Walter Energy) to approximately $\$ 302.5$ billion (Exxon Mobil), with an average of $\$ 32.7$ billion. In terms of revenue generation, they range from about $\$ 520$ million in annual sales (EXCO Resources) to $\$ 342$ billion (Exxon Mobil), with mean sales of approximately $\$ 29$ billion. Table 6 provides descriptive statistics for the firms in our combined sample.

Table 6: Descriptive Statistics for Firms in Combined Sample

\begin{tabular}{|l|r|r|r|r|r|}
\hline & $\mathrm{N}$ & \multicolumn{1}{|c|}{ Minimum } & Maximum & \multicolumn{1}{c|}{ Mean } & Std. Deviation \\
\hline Sales2010 & 43 & .52 & 341.60 & 28.6861 & 62.89131 \\
Profits2010 & 43 & -1.10 & 30.50 & 2.3717 & 5.52759 \\
Assets2010 & 43 & 1.70 & 302.50 & 32.7028 & 55.08475 \\
Market Cap & 43 & 3.50 & 407.20 & 34.8558 & 67.33764 \\
Valid N (listwise) & 43 & & & & \\
\hline
\end{tabular}

Dependent Variable

Our variable of interest in this study is whether the firm was a defendant in an ATS lawsuit filed by an NGO plaintiff or with NGO legal representation between 1996 
and 2010. A "1" indicates that the firm was sued at least once during the 15 -year time series; a "0" indicates that the firm was not sued.

\section{Independent Variables}

We examine whether certain characteristics of the corporate defendant are associated with a higher probability of being sued to test hypotheses 1-4. According to hypothesis 1 (Social performance), firms with poor social performance should experience a higher probability of being sued. To assess this hypothesis, we use data from Kinder, Lydenburg, Domini's (KLD) Socrates database, accessed through Wharton Research Data Services (WRDS). The KLD index is the most commonly used measure of corporate social performance (Hillman \& Keim, 2001). It has been extensively used in empirical research in the fields of strategy (Waddock \& Graves, 1997; Godfrey et al., 2009), international business (Strike, Gao, \& Bansal, 2006), and business and society (Rehbein et al., 2004).

Derived from a variety of sources including annual surveys, annual reports, proxy statements, quarterly reports, and articles in the business press, the KLD index assesses the corporate social performance of some 650 publicly listed U.S.-based firms along a series of dimensions ranging from community relations to the treatment of women and minorities. Each of the 12 KLD categories contains a number of items which are assigned a "1" or a " 0 " depending on whether the firm meets certain criteria. Seven of these categories are qualitative in the sense that they consist of both strengths and concerns, whereas the other five are exclusionary, in that they are comprised of concerns only. Following past research (e.g., Strike et al., 2006; Godfrey et al., 2009) we use the seven 
qualitative categories (community involvement, corporate governance, employee relations, environmental stewardship, diversity, human rights, and product quality) to create a composite social responsibility variable for each firm. We do this by adding the strengths and subtracting the weaknesses for each category of each year, and then averaging these firm-year scores across the entire time series (Rehbein et al., 2004).

According to hypothesis 2 (firm size), firms that are large in size should experience a higher probability of being sued because their social prominence makes them attractive targets for activists seeking to maximize publicity and mobilize support. Although researchers have used various measures as proxies for firm size, including total sales (David et al., 2007; Hillman, Shropshire, \& Canella, 2007; Hambrick \& Canella, 2004) and number of employees (Rehbein et al., 2004), total assets is the most commonly used measure in the strategy and IB literatures (Lenox \& Eesley, 2009; Strike et al., 2006; Bartley \& Child, 2007; Eesley \& Lenox, 2005; Oxley \& Schnietz, 2001; King, 2008). As such, we obtain the total assets of each firm in the sample from Compustat and calculate its average over the 15-year time series.

According to hypothesis 3 (reputation), firms that have reputations for being admired are more likely to be targeted with ATS lawsuits than those without such reputations. To assess this hypothesis, we use data from Fortune magazine's list of America's Most Admired Companies. Published every year since 1983, the Fortune list reports the results of a survey conducted the previous year of some 10,000 business executives and market analysts. These executives are asked to rate the top firms in their own industries based on eight criteria: innovation, financial soundness, employee talent, use of corporate assets, long-term investment value, social responsibility, quality of 
management, and quality of products and services. Many organization researchers have used the Fortune list as an indicator of a company's overall reputation among stakeholders (King, 2008; Fombrun \& Shanley, 1990; Staw \& Epstein, 2000; Brown \& Perry, 1994; Roberts \& Dowling, 2002). Indeed, it is the most commonly used measure of corporate reputation in current strategy and organization research (Sabate \& Puente, 2003; Basdeo et al., 2006). Since there is only minor variation in the list's composition from year to year, we follow past research and create a dichotomous reputation variable, coding the firm " 1 " if it appeared on the list in any year of the time series, and " 0 " otherwise (Bartley \& Child, 2007).

To test hypothesis 4, that firms with better financial performance should experience a higher probability of being sued, we calculate the firm's return on assets (ROA). A commonly used measure of profitability, ROA involves dividing the firm's annual net income by its total assets (Waddock \& Graves, 1997; Bartley \& Child, 2007; Roberts \& Dowling, 2002). Our measure is the natural logarithm of the mean ROA for each firm in the sample over the 15 year time series. Log transformation was performed to assist with interpretation (Contractor, Kundu, \& Hsu, 2003).

\section{Statistical Analysis}

We examine the relationship between firm characteristics and the probability of being sued under ATS by estimating a binary logistic regression model (Tabachnick \& Fidell, 2007). Logistic regression, which predicts the probability of an outcome (e.g., membership in a group) based on a set of predictor variables, is the appropriate statistical technique for this study since our research question deals with the issue of prediction and 
our dependent variable is categorical in nature (sued/not sued) (Mertler \& Vannatta, 2005). As Fraas and Newman (2003) observe, the procedure used to calculate the coefficients in logistic regression compares the probability of an event occurring with the probability of its not occurring for each subject in the sample. This ratio of the two probability values is referred to as the odds value.

While other techniques such as OLS and discriminant analysis could have been employed, logistic regression has several advantages (Newman, Brown, \& Fraas, 2004). First, it requires no assumptions about the distributions of the explanatory variables be made by the researcher - they may be normally distributed, linearly related, or have equal variances within each group (Tabachnick \& Fidell, 2007). Second, the probability values generated by a logistics regression are bounded by the values of zero and one - unlike the values estimated by an OLS regression model (Fraas \& Newman, 2003). As such, logistic regression is a particularly versatile statistical technique well suited to this research.

XVII. Results

Table 7 provides a correlation matrix for our dependent and independent variables. As can be seen, all of the independent variables are correlated with our variable of interest. 
Table 7: Correlation Matrix

\section{Correlations}

\begin{tabular}{|ll|r|r|r|r|r|}
\hline & & Lawsuit & \multicolumn{1}{c|}{ KLD } & Assets_log & Admired & ROA_x_100 \\
\hline Lawsuit & Pearson Correlation & 1 & $.588^{* *}$ & $.405^{* *}$ & $.327^{*}$ & $.457^{* *}$ \\
& Sig. (2-tailed) & & .000 & .004 & .020 & .001 \\
& $\mathrm{~N}$ & 50 & 50 & 50 & 50 & 50 \\
\hline \multirow{2}{*}{ KLD } & Pearson Correlation & $.588^{* *}$ & 1 & $.339^{*}$ & .262 & $.319^{*}$ \\
& Sig. (2-tailed) & .000 & & .016 & .066 & .024 \\
& $\mathrm{~N}$ & 50 & 50 & 50 & 50 & 50 \\
\hline \multirow{2}{*}{ Assets_log } & Pearson Correlation & $.405^{* *}$ & $.339^{*}$ & 1 & $.543^{* *}$ & .268 \\
& Sig. (2-tailed) & .004 & .016 & & .000 & .060 \\
& $\mathrm{~N}$ & 50 & 50 & 50 & 50 & 50 \\
\hline \multirow{2}{*}{ Admired } & Pearson Correlation & $.327^{*}$ & .262 & $.543^{* *}$ & 1 & .143 \\
& Sig. (2-tailed) & .020 & .066 & .000 & & .323 \\
& $\mathrm{~N}$ & 50 & 50 & 50 & 50 & 50 \\
\hline \multirow{2}{*}{ ROA_x_100 } & Pearson Correlation & $.457^{* *}$ & $.319^{*}$ & .268 & .143 & 1 \\
& Sig. (2-tailed) & .001 & .024 & .060 & .323 & 50 \\
& $\mathrm{~N}$ & 50 & 50 & 50 & 50 & 50 \\
\hline
\end{tabular}

${ }^{* *}$. Correlation is significant at the 0.01 level (2-tailed).

*. Correlation is significant at the 0.05 level (2-tailed).

To assure that multicollinearity amongst the predictor variables was not a problem, we performed an OLS regression to generate variance inflation factors and found that none exceeded 3, a value well below the accepted maximum of 10 (Tabachnick \& Fidell, 2007) (See Table 8). 
Table 8: Tolerance Statistics for Independent Variables

\begin{tabular}{|c|c|c|c|c|c|c|c|}
\hline & & & Coefficients $^{a}$ & & & & \\
\hline \multirow[t]{2}{*}{ Model } & \multicolumn{2}{|c|}{ Unstandardized Coefficients } & $\begin{array}{l}\text { Standardized } \\
\text { Coefficients }\end{array}$ & \multirow[b]{2}{*}{$\mathrm{t}$} & \multirow[b]{2}{*}{ Sig. } & \multicolumn{2}{|c|}{ Collinearity Statistics } \\
\hline & B & Std. Error & Beta & & & Tolerance & VIF \\
\hline (Constant) & -.677 & .421 & & -1.610 & .114 & & \\
\hline KLD & .086 & .024 & .430 & 3.566 & $.001^{\star *}$ & .820 & 1.219 \\
\hline Assets_log & .048 & .051 & .129 & .947 & 349 & .644 & 1.552 \\
\hline Admired & .097 & 120 & 106 & .813 & .421 & .698 & 1.433 \\
\hline ROA_x $\_100$ & .035 & .015 & 269 & 2.298 & $.026^{* *}$ & .868 & 1.152 \\
\hline
\end{tabular}

a. Dependent Variable: Lawsuit

** $=$ significant at $p<.05$

Next, we ran a binary logistic regression to determine whether any of our independent variables (social performance; firm size; reputation; and financial performance) were predictors of the likelihood of ATS legal action (sued/not sued). Our regression results indicate the overall model was statistically significant in distinguishing between sued and not sued firms. The -2 Log Likelihood provides an index of model fit. A perfect model would have a -2 Log Likelihood of 0 ; the lower this value, the better the models fits the data (Mertler \& Vannatta, 2005). The -2 Log Likelihood coefficient for our model (29.082) indicates a good fit. The chi-square for our model (29.084) is significant $(\mathrm{p}<.0001)$, suggesting that the model is significantly better in predicting subject membership than the constant-only model (Mertler \& Vannatta, 2005). Cox \& Snell R-square and Nagelkerke R-square coefficients of .454 and .653, respectively, indicate that our model accounts for a substantial proportion of the variability in our 
dependent variable - whether a firm was sued. Table 9 provides several indices of overall model fit.

Table 9: Indices of Model Fit

\begin{tabular}{|l|r|r|c|}
\hline Step & & $\begin{array}{c}\text { Mox \& Snell R } \\
\text { Square }\end{array}$ & $\begin{array}{c}\text { Nagelkerke R } \\
\text { Square }\end{array}$ \\
\hline 1 & $29.084^{\mathrm{a}}$ & .454 & .653 \\
\hline
\end{tabular}

a. Estimation terminated at iteration number 7 because parameter estimates changed by less than .001 .

Table 10 presents the classification table. As can be observed, the model did a somewhat better job correctly predicting firms that were not sued (94.4\%) than firms that were sued (78.6\%). Overall, our model correctly classified $90 \%$ of the cases. In other words, we can infer that our model would correctly predict the likelihood that a new firm would be sued under ATS nine times out of ten.

Table 10: Classification Table

Classification Table ${ }^{\mathrm{a}}$

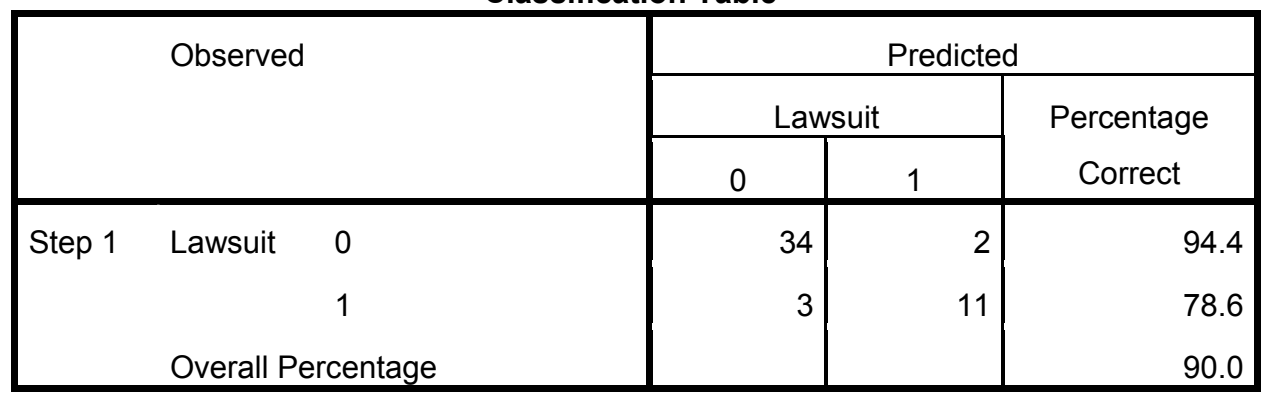

a. The cut value is .500 
The summary of model variables is displayed in Table 11. Our results include Wald statistics for each coefficient. ${ }^{52}$ A logistic coefficient is considered to differ significantly from zero when the probability value of the Wald statistic is less than the established alpha level (Fraas \& Newman, 2003). The Wald logistic coefficients indicate that both social performance (as determined by KLD ratings) (.013) and financial performance (ROA) (.021) significantly predict the likelihood of being sued $(\mathrm{p}<.05)$. Both signs are in the right direction as well, indicating that a higher KLD score (i.e., greater net number of concerns) and higher return on assets are positively associated with the likelihood of being sued. Neither of the other two independent variables is significant at conventional levels. The results in Table 11 are consistent with those generated from our OLS model (Table 8). In that model, both social performance and financial performance account for a significant amount of variance that is unique from that accounted for by other variables.

Table 11: Summary of Model Variables

Variables in the Equation

\begin{tabular}{|ll|r|r|r|r|r|r|}
\hline & B & S.E. & Wald & df & Sig. & $\operatorname{Exp}(\mathrm{B})$ \\
\hline Step $1^{\mathrm{a}}$ & KLD & .840 & .340 & 6.104 & 1 & $.013^{* *}$ & 2.317 \\
& Assets_log & -.276 & .564 & .239 & 1 & .625 & .759 \\
& Admired & 2.805 & 1.712 & 2.686 & 1 & .101 & 16.531 \\
& ROA_x_100 & .437 & .190 & 5.312 & 1 & $.021^{* *}$ & 1.548 \\
& Constant & -6.194 & 4.045 & 2.345 & 1 & .126 & .002 \\
\hline
\end{tabular}

a. Variable(s) entered on step 1: KLD, Assets_log, Admired, ROA_x_100

** = significant at $\mathrm{p}<.05$

${ }^{52}$ The Wald test is the square ratio of its coefficient to its standard error (Fraas \& Newman, 2003). 
Further insights into our results may be gleaned by examining the odds ratios of the regression coefficients in Table 10. Odds ratios represent the change in the likelihood of a dependent variable arising from a one-unit change in the independent variable. An odds ratio of 1.00 indicates no effect. Odds ratios of greater than 1.00 indicate that increases in the independent variable increase the likelihood of the dependent variable in this case the likelihood of being sued. Odds ratios of less than 1.00 indicate negative associations, or that increases in the independent variable decrease the likelihood of being sued (Hillman et al., 2006).

Hypothesis 1 predicts that social performance will be negatively associated with ATS lawsuit filings. Firms with good social performance are expected to be less attractive targets for activists than firms that abuse workers and the environment. The evidence in Table 10 supports this interest-based hypothesis. The odds ratio for our social performance measure indicates that moving from the sample mean to one unit below the mean in social performance more than doubles the likelihood of being sued (odds ratio $=$ 2.317, $\mathrm{p}<.05$ ). This finding is consistent with past research by Lenox and Eesley (2009), who found that ENGOs tend to target the firms with poor environmental performance (i.e., high toxic emissions).

Hypothesis 2 predicts that firm size will be positively associated with ATS lawsuit filings. Larger firms are expected to be more attractive targets for activist groups. The evidence in Table 10 does not support this identity-based hypothesis (odds ratio = 1.00). This result is somewhat surprising given that past research has demonstrated that activist groups tend to target large firms for both boycotts (King, 2008) and shareholder resolutions (Rehbein et al., 2004). A possible explanation is that activist groups that file 
ATS lawsuits have less discretion over whom they can sue than groups initiating other types of anti-corporate challenges since there must be a legal basis for their claims, and as such, targeting the largest firms, while perhaps desirable, is not always feasible. Another possibility is that NGOs initiating ATS lawsuits avoid suing the largest firms owing to the possibility that these resource-rich firms will be more formidable opponents and less likely to make concessions. A third possibility is that smaller MNEs are more likely to commit human rights violations than larger MNEs, which presumably have greater resources to devote to human-rights related training and due diligence.

Hypothesis 3 predicts that firm reputation will be positively associated with ATS lawsuit filings. Better reputed firms are expected to be more attractive targets for activist groups. The evidence in Table 10 does not support this identity-based hypothesis (odds ratio $=1.00)$. This result is also somewhat surprising given King's (2008) finding that activist groups tend to boycott firms with strong reputations. Again, it is possible that NGOs that file ATS litigation have less discretion in their targeting choices than do firms employing alternative tactics and cannot always select firms with good reputations in hopes of tarnishing these intangible assets. It is also possible that firms with good reputations tend to be better corporate citizens and avoid engaging in the types of behaviors abroad that are likely to result in litigation.

Hypothesis 4 predicts that firm financial performance will be positively associated with ATS lawsuit filings. Firms with better financial performance are expected to be more attractive targets for activist groups. The evidence in Table 10 supports this identity-based hypothesis. The odds ratio for our financial performance measure indicates that moving from the sample mean to one unit above the mean in financial performance 
increases the likelihood of being sued by roughly 55 percent (odds ratio $=1.548, \mathrm{p}<.05$ ). This finding is consistent with King (2008), who found that activist groups tend to boycott firms that have experienced weak financial performance, and Eesley and Lenox (2005), who reported that ENGOs tend to select firms that are financially sound as targets for anti-corporate campaigns involving boycotts, protests, lawsuits, letter-writing campaigns, and shareholder resolutions.

\section{Discussion}

This research contributes to the growing body of empirical literature that examines the private political strategies of activist groups (Baron, 2003; King, 2008; Eesley \& Lenox, 2009; Lenox \& Eesley, 2005; Bartley \& Child, 2007; Rehbein et al., 2004; Reid \& Toffel, 2009). Given the rise in transnational tort-related litigation against MNEs in recent years - and the attention these cases have garnered from business executives, policymakers, and the press -- we felt it important to assess how NGOs that file human rights-related civil litigation select their corporate targets. We chose to study ATS lawsuits filed against extractive companies given the size and importance of this industry to the global economy - in 2006, the world's 39 largest publicly listed oil companies generated nearly $\$ 2.8$ trillion in revenue (Rangan \& Barton, 2010) -- and the fact that roughly one-quarter of all the corporate ATS lawsuits filed to date have been against firms engaged in natural resource extraction or production (Drimmer, 2010).

Our results suggest that activist groups sometimes choose their corporate targets with the aim of changing the practices of social performance laggards (i.e., based on what they do). But they also indicate that some ATS lawsuits are targeted at highly profitable 
firms, irrespective of their social performance (i.e., based on who they are). Although we did not directly test our general propositions, it is possible to infer from these results that stakeholder groups are motivated by both interest and identity-based rationales in choosing corporate targets for ATS lawsuits - a finding that is broadly consistent with past empirical research on stakeholder activism (de Bakker \& den Hond, 2007; Rehbein et al., 2004).

Our findings have important implications for theory. Despite more than 25 years of research on stakeholder theory since Freeman's seminal contribution (1984), scholars know relatively little about the mechanisms by which external agents influence organizational behavior and the contextual factors that moderate their success (de Bakker \& den Hond, 2008; King \& Soule, 2007; LaPlume, Sonpar, \& Litz, 2008). By identifying the factors that underlie the targeting decisions of NGOs initiating ATS legal challenges against MNEs, this research addresses the gap in our knowledge of the motives and tactical choices stakeholders make (de Bakker \& den Hond, 2008), thereby advancing stakeholder theory.

This research also has significance for practice. Given the sharp rise in tort-related lawsuits against MNEs in recent years, managers need to have a better understanding of the likelihood of litigation prior to entering new markets - particularly since the anecdotal evidence suggests that financial markets respond unfavorably to the filing of ATS lawsuits (Kobrin, 2004; Kurlantzick, 2004). Our finding that stakeholder groups select their targets for ATS litigation based in part on their conduct -- confronting firms with poor social performance -- would seem to provide a strong justification for firms to improve their overseas practices and stakeholder relations. Possible avenues for action 
might include adopting private certification schemes (Conroy, 2007; Vogel, 2008) and embracing cross-sectoral partnerships with NGOs (Dahan et al., 2010). But it is also possible that managers may seek to blunt the threat of ATS litigation by undertaking political moves to defeat the litigation or making cosmetic changes to policies and practices (David, Bloom, \& Hillman, 2007; Shamir, 2004). Future research might seek to tease out the factors that influence firm response to civil litigation. To this end, Spar and LaMure (2003) offer a framework that may serve as a useful starting point. They identify three strategies that firms facing activist pressure may adopt: preemption, capitulation, and resistance, with the choice of strategy being influenced by transaction costs, brand impact, and competitive position.

Future research also might examine whether there are significant differences amongst activist groups that file corporate ATS litigation and whether these differences influence their targeting decisions. For instance, it is possible that some stakeholder groups are motivated primarily by an interest in changing the target firm's behavior, while other are driven largely by a desire to attract publicity, generate resources, and achieve individual notoriety. A better understanding of the motivations of different stakeholder groups could enable corporate managers to craft more effective risk mitigation strategies.

Another important avenue of inquiry involves examining whether there are systematic differences in the types of firms targeted for lawsuits by NGOs and those targeted by private class-action laws firms. This is a matter of some urgency given the increase in transnational tort litigation filed by class-action attorneys working on contingency fees (Fergenson \& Merrigan, 2007). 
While this research makes an important contribution to our understanding of stakeholder legal activism directed against MNEs, it has several limitations. First it examines only a single industry and it is not clear that the findings are generalizable beyond the extractive sector. Second, it analyzes ATS lawsuits filed against U.S. firms only and it is possible that the targeting decisions of NGOs vary with respect to foreign firms, which are also liable under ATS. Third, it considers only characteristics of the target firm as determinants of stakeholder action and it is possible that characteristics of the NGOs (e.g., ideology, power, and legitimacy) could play an important role in targeting decisions (den Hond \& de Bakker, 2007; Eesley \& Lenox, 2006). Fourth, it is possible that firms are targeted not because of interest or identity factors, but because of opportunities. For example, large firms are more likely than small firms to have complex, operations involving subsidiaries in multiple foreign countries, and it is this complexity which may create exposure to lawsuits (Miles 1987).

Notwithstanding these caveats and limitations, this research provides evidencebased insights into the strategic and tactical decision-making of NGOs pursuing humanrights-related litigation that will hopefully stimulate further research into this important, emerging area of business-society relations.

\section{IXX. Conclusion}

MNEs with operations in the developing world face a growing number and variety of non-market risks that threaten their ability to profit from their investments (Chambers et al., 2010; Grosse, 2005; Henisz, Mansfield, \& Von Glinow, 2010). Among these is the possibility that they will be sued by secondary stakeholder groups in U.S. federal courts over allegations of complicity in overseas human rights abuses. Given the 
huge potential liabilities associated with these cases, they can represent "bet-the-company risks" (Brown, 2011). These risks are exacerbated when stakeholder groups employ extra-legal tactics to gain leverage in the legal proceedings. This dissertation contends that the threat of transnational legal activism represents a new and serious concern to global business that merits attention from management, IB, and strategy researchers. By examining the antecedents and consequences of such legal activism in both conceptual and empirical settings, this work provides a foundation for future scholarship.

As this dissertation shows, the filing of ATS lawsuits is associated with a significant loss of shareholder wealth in the weeks leading up to the filing - a loss which is far greater in magnitude than that associated with other stakeholder tactics such as protests (King \& Soule, 2007) and boycotts (Zadek, 2001). Whether the markets react because of expectations that the legal process will be lengthy and costly and divert managerial attention from running the company, or because it may lead to a costly settlement, or because it may culminate in a billion-dollar judgment at trial, or simply because it may result in serious reputational harm is unclear and warrants future investigation.

What is clear, however, is that investors view these lawsuits as significant events that cloud the target firm's future economic prospects. This research also suggests that activist groups select targets for litigation-based campaigns based on both who they are (i.e., highly profitable companies) and what they do, with extractive firms viewed as poor social performers facing a higher probability of being sued than those with better social performance. 
This research has implications for theory, practice, and policy. From a theoretical standpoint, it contributes to the scholarly effort to understand how a range of relatively resource-poor, powerless, and marginalized stakeholder groups (Gardberg \& Newburry, 2010) are using "voice" (Hirschman, 1970) to challenge corporate policies and practices, promote institutional change, and press for new and binding global norms governing the conduct of international business (Vogel, 2010). These groups include NGOs (Doh \& Teegen, 2003; Yaziji \& Doh), social movements (King \& Soule, 2007; King, 2008; Soule, 2009), and transnational advocacy networks (Riesse et al., 1999). It also addresses the gap in our knowledge of the motives and tactical choices of stakeholder groups that target corporations and the consequences of these actions (de Bakker \& den Hond, 2008), thereby advancing stakeholder theory.

This research also has relevance for practice. Given the sharp rise in human rights-related lawsuits against MNEs in recent years, managers need to have a better understanding of the likelihood and costs (both direct and indirect) of litigation prior to entering new markets - particularly those with endemic human and labor rights violations, ethnic and social cleavages, and a recent history of political turmoil. Our findings provide strong justification for multinational managers to seek ways to improve their overseas business practices and stakeholder relations, so as to make their firms less attractive targets. But our research suggests that becoming a model corporate citizen may not immunize a firm from being targeted by stakeholder groups with identity-based motivations.

This research also has important policy implications. The sharp rise in foreign direct investment to emerging markets in recent years has been heralded as a promising 
development in global economic affairs (Khanna \& Palepu, 2010). But if MNEs perceive the legal risks of doing business in emerging markets to be too great, they may scale back their investments or withdraw entirely, with grave consequences for local development (Hufbauer, 2009). There is some evidence that such a retrenchment is already occurring. Chiquita, which has been sued numerous times under the ATS in recent years owing to revelations that the company paid "protection money" to left-wing and right-wing terrorist organizations in Colombia, sold off its Colombian assets in 2004 -- reportedly at a significant financial loss (Baue, 2007). Canada's Talisman Energy, another target of ATS litigation, divested its $\$ 770$ million stake in a Sudanese petroleum project in 2002. Meanwhile, Exxon Mobil announced in August 2011 that it was selling off its interests in three natural gas companies in Aceh, Indonesia - less than a month after a previously dismissed ATS lawsuit stemming from alleged human rights violations by Indonesian soldiers protecting its Aceh facilities was reinstated by a U.S. federal appeals court (Driver, 2001). ${ }^{53}$

U.S. government officials and policy analysts have also warned that the growing tide of ATS litigation could strain relations with foreign governments, which object to U.S. efforts to impose its legal authority over what they view as purely domestic matters (Davis, 2008), and prompt the exit of Western MNEs from countries with weak governing institutions, to the detriment of U.S. policy in the struggle against international terrorism (Shamir, 2004). A related worry is that the departure of Western firms from

\footnotetext{
${ }^{53}$ The lawsuit, brought by Indonesian villagers who claim that they and their family members were beaten, tortured, kidnapped, raped, and murdered by Indonesian soldiers guarding Exxon's natural gas operations, was dismissed in 2009, but overturned by the U.S. Court of Appeals for the District of Columbia Circuit in a 2-1 ruling (Kendall, 2011).
} 
developing nations in Asia, Africa, and Latin America could open the door to stateowned firms from emerging nations that are less beholden to pressures from civil society and less committed to social responsibility (Schrage, 2003). Indeed, when Talisman Energy divested from an oil pipeline project in the Sudan in 2003 amidst intense stakeholder pressure, India's state-owned oil company ONGC Videsh Limited purchased its assets. The project continues to this day, but without the community development projects and transparency initiatives that Talisman claims it had implemented (Manhas, 2007).

But a compelling argument can also be made that corporate liability for overseas human rights violations under ATS actually advances U.S. national interests. For one, it may promote exemplary corporate conduct in a way that voluntary and non-binding CSRrelated initiatives do not (Vogel, 2010), thereby showing authoritarian host governments and their citizens how responsible capitalism and democratic politics can go hand in hand. Indeed, as Herz (2008: 228) observes, "the potential for aiding and abetting liability ensures that corporation will not only explain democratic values and institutions to repressive governments, but will also demonstrate that those values and institutions are not merely aspirations but actually govern the conduct of members of a democratic society."

Additionally, by pressuring MNEs to avoid or divest from countries where basic human rights are not upheld, such litigation may prompt host governments to clean up their acts in order to avoid pariah status from international investors. As Kurlantzick (2004: 66) observes, MNEs appear to be in a unique position to influence authoritarian regimes in places like Myanmar that have resisted the demands of NGOs and foreign 
governments to reform: "Officials close to the Rangoon junta say that the regime cares little about the pressure tactics of the United States, Britain, and other Western governments, because they have little impact on the everyday lives of the generals. But, the officials say, Yangon's military leaders do pay attention when companies pull out, since a collapsing economy hits their pocketbooks."

Meanwhile, to the extent that the threat of extraterritorial litigation encourages MNE managers to be more discerning when choosing foreign business partners, more directly involved in formulating policies governing operations, and more vocal in their advocacy of human rights within their firms and across their supply chains, it may serve a useful purpose (Schrage, 2003). The net result may not only be higher workplace standards and safer working conditions in overseas factories, farms, and mines, but more productive and committed workers, greater legitimacy, less business risk, and enhanced sustainability.

While these policy questions are not likely to be settled any time soon, this research helps clarify them, while contributing to our understanding of an important new phenomena in business-society relations with profound implications for MNEs, their stakeholders, and host societies. 


\section{LIST OF REFERENCES}

Agle, B. R., Mitchell, R. K. and Sonnenfeld, J. A. (1999) "Who matters to CEOs? An investigation of stakeholder attributes and salience, corporate performance, and CEO values." Academy of Management Journal, 42(5): 507-525.

Agrawal, J. and Kamakura, K. A. (1995) "The economic worth of celebrity endorsers: An event study analysis.” Journal of Marketing, 59(3): 56-62.

Alon, I., Gurumoorthy, R., Mitchell, M. C., and Steen, T. (2006) "Managing micro political risk: a cross-sector examination." Thunderbird International Business Review, 48(5): 623-642.

Alon, I., and \& Herbert, T. T. (2009) "A Stranger in a strange land: Micro political risk and the multinational firm." Business Horizons, 52, 127-137.

Ashforth, B. E., and Kreiner, G.E. (1999) "How can you do it? Dirty work and the challenge of constructing a positive identity." Academy of Management Review, 24: 413434.

Banks, D. W. and Kinney, W. R. (1982) "Loss contingency reports and stock prices: an empirical study." Journal of Accounting Research, 20: 240-54.

Bansal, P. (2005) "Evolving sustainably: a longitudinal study of corporate sustainable development." Strategic Management Journal, 26: 197-218.

Baron, D. P. (2001) "Private politics, corporate social responsibility and integrated strategy.” Journal of Economics and Management Strategy, 10: 7-45.

Baron, D. P. (2003) "Private politics." Journal of Economics and Management Strategy, 10: 7-45.

Baron, D. P. \& Diermeier, D. (2007) "Strategic activism and nonmarket strategy." Journal of Economics \& Market Strategy," 16(3): 599-634.

Barret, P. M. (2011) "Chevron Looks to Its Home Court for a Comeback Win." Bloomberg Businessweek, 18 July.

Bartley, T. (2007) "How foundations shape social movements: the construction of an organizational field and the rise of forest certification." Social Problems, 54(3): 229-255.

Bartley, T. and Child, C. (2007) "Shaming the corporation: Globalization, reputation, and the dynamics of anti-corporate movements." Working paper, Indiana University, Bloomington, IN. http://www.indiana.edu/ tbsoc/ (Accessed 12 May 2011). 
Baue, B. (2007) "To avoid risk of Alien Tort Claims Act cases, companies must improve human rights." Socialfunds.com, 17 August.

Baye,, M. R., Kovenock, D. and de Vries, C. G. (2005) "Comparative analysis of litigation systems: An auction-theoretic approach." The Economic Journal, 115(505): 583-601.

Beer, M. (2009) High commitment, high performance: How to build an organization for sustained competitive advantage. San Francisco: Josey-Bass.

Bhagat, S., Bizjak, J. and Coles, J. L. (1998) "The shareholder wealth implications of corporate lawsuits." Financial Management, 27(4): 5-28.

Bhagat, S., Brickley, J. A., and Coles, J. L. (1994) "The costs of inefficient bargaining and financial distress." Journal of Financial Economics, 35: 221-247.

Bhagat, S. and Romano, R. (2007) "Empirical studies of corporate law." in Polinsky, M. and Shavell, S. (eds.), Handbook of Law and Economics. Harvard Law School.

Black, E., Carnes, T., and Richardson, V. (2000) "The market valuation of corporate reputation." Corporate reputation review, 3(1): 31-42.

Bonardi, J. P. and Keim, G. D. (2005) "Corporate political strategies for widely salient issues." Academy of Management Review, 30(3): 555-576.

Bonardi, J. P., Hillman, A., and Keim, G. D. (2005) "The attractiveness of political markets: Implications for firm strategy. Academy of Management Review, 30(2): 397413.

Brown, R. M. (2011). “Corporate responsibility to respect human rights." Memorandum. http://bit.ly/ozf2BU

Brown, S. J. and Warner, S. (1985) "Using daily stock returns: the case of event studies." Journal of Financial Economics, 14: 3-31.

Campbell, D. (2011) “Lessons from Talisman Energy Inc.'s Sudanese foray.” Alberta Oil Magazine, 1 June. http://www.albertaoilmagazine.com/2011/06/there-will-be-risk/ (Accessed 16 June 2011)

Carroll, J. and Gullo, K. (2011) “Chevron's \$17 billion Ecuador judgment may be unenforceable, analysts say."Bloomberg, 15 February.

Center for Legal Policy (2011) "The litigation industry." Manhattan Institute for Policy Research, www.manhattan-institute.org 
Chambers, D., Wernick, D., Zdanowicz, J. and Von Glinow, M. A. (2010) How Dangerous Are Measurement Errors to Homeland Security? Thunderbird International Business Review, 52(6): 553-569.

Clarkson, M. B. E. (1995) “A stakeholder framework for analyzing and evaluating corporate social performance." Academy of Management Review, 20(1): 92-117.

Clinebell, S. K., and Clinebell, J. M. (1994) "The effect of advanced notice of plant closings on firm value." Journal of Management, 20: 553-564.

Conroy, M. (2007) Branded! How the 'certification revolution' is transforming global corporations. Galbriola Island, BC, Canada: New Society.

Contractor, F., Kundu, S. and Hsu, C. (2003) "A three-stage theory of international expansion: the like between multinationality and performance in the service sector." Journal of International Business Studies, 34: 5-18.

Cooper, M. (2006) "Danish energy firm will stop buying from Drummond, pending court case," Platts Coal Outlook, 27 November.

Crumb, M. J. (2010) "PETA stock: Group has shares in 80 companies; finds influence in boardroom." Associated Press, 24 May.

Cyert, R. M. and March, J. G. (1963) A behavioral theory of the firm. Englewood Cliffs, N. J.: Prentice-Hall.

Dahan, N. M., Doh, J. P., Oetzel, J., and Yaziji, M. (2010) "Cooperation and co-creation in cross-sectoral collaboration: New business models for developing markets." Long Range Planning, 43(2-3): 326-342.

David, P., Bloom, M., and Hillman, A. J. (2007) "Investor activism, managerial responsiveness, and corporate social performance.” Strategic Management Journal, 28, 91-100.

Davidson, W. N. III, Worrell, D. L., and El-Jelly, A. (1995) "Influencing managers to change unpopular corporate behavior through boycotts and divestitures: A stock market test." Business \& Society, 34: 177-196.

Davidson, W., and Worrell, D. (1992) "The effect of product recall announcements on shareholder wealth." Strategic Management Journal, 13: 467-473.

Davis, J. (2008) Justice Beyond Borders: The Struggle for Human Rights in U.S. Courts. New York: Cambridge University Press.

Davis, G. F., Morill, C., Rao, H., and Soule, S. (2008). "Introduction: Social movements in organizations and markets." Administrative Science Quarterly, 53, 389-394. 
Davis, G. F., McAdam, D., Scott, W. R. and Zald, M. N. (Eds.) Social Movements and Organization Theory, Cambridge: Cambridge University Press.

Davis, G. F. and Zald, M. N. (2005) "Social Change, Social Theory, and the Convergence of Movements and Organizations." In Davis, G. F., McAdam, D., Scott, W. R. and Zald, M. N. (Eds.) Social Movements and Organization Theory, Cambridge: Cambridge University Press.

Davis, G. F., Morrill, C., Rao, H. and Soule, S. A. (2008) "Introduction: Social movements in organizations and markets." Administrative Science Quarterly, 53: 389394.

De Bakker, F. G. A. and Den Hond, F. (2008) "Introducing the Politics of Stakeholder Influence: A Review Essay.” Business and Society, 47: 8-20.

Deephouse, D. and Carter, S. M. (2005) “An Examination of Differences Between Organizational Legitimacy and Organizational Reputation.” Journal of Management Studies, 42:2, 329-360.

Della Porta, D. and Mario, D. (1999) Social movements: An introduction. Malden, MA: Blackwell Publishing.

De la Torre, J. and Neckar, D. H. (1988) "Forecasting political risks for international operations." International Journal of Forecasting, 4 (2): 221-241.

Den Hond, F., De Bakker, F. G. A. (2007) "Ideologically motivated activism: how activist groups influence corporate social change activities." Academy of Management Review, 32(3): 901-924.

Doh, J. P., Howton, S. D., Howton, S. W., Siegel, D. S. (2010) "Does the Market Respond to an Endorsement of Social Responsibility? The Role of Institutions, Information, and Legitimacy." Journal of Management, 36(6): 1461-1485.

Doh, J. P., Newburry, W. E., and Teegen, H. (2003) "Cooperative strategies in environmental nongovernmental organizations." In Doh, J. P. and Teegen, H. (eds.). (2003) Globalization and NGOs: Transforming business, government and society. Westport, CT: Praeger.

Doh, J. P., and Teegen, H. (2003) Globalization and NGOs: Transforming business, government and society. Westport, CT: Praeger.

Dovey, K. (2009) "Human rights." Berkshire Encyclopedia of Sustainability: The Business of Sustainability, 276-281. 
Drimmer, J. C. (2010) Think globally, sue locally: Out-of-court tactics employed by plaintiffs, their lawyers, and their advocates in transnational tort cases. Washington, D.C.: U.S. Chamber Institute for Legal Reform.

Drimmer, J. C. and Lamoree, S. R. (2011) "Think globally, sue locally: trends and out-ofcourt tactics in transnational tort actions. Berkeley Journal of International Law, 29(2): 456-527.

Drimmer, J. C. and Millerwise Dyck, J. (2009) "Human rights lawsuits: mitigating a new threat." Oil \& Gas Journal, 5 October.

Driver, A. (2011) “Exxon selling Indonesia assets linked to lawsuit.” Reuters, 8 August.

Dunst, L. G. (2010) “On the frontier of Alien Tort Claims.” New York Law Journal, 19 July.

Eesley, C. and Lenox, M. (2005) "Secondary Stakeholder Actions and the Selection of Firm Targets." Working Paper, Proceedings of the 2006 Academy of Management Conference. Atlanta, GA. August, 2006.

Eesley, C. and Lenox, M. J. (2006) "Firm responses to secondary stakeholder action." Strategic Management Journal, 27: 765-781.

Epstein, M. and Schnietz, K. (2002) "Measuring the cost of environmental and labor protests to globalization." International Trade Journal, 16(2): 129-160.

Fama, E. F. (1970) "Efficient capital markets: A review of theory and empirical work." Journal of Finance, 25: 383-417.

Fergenson, A. and Merrigan, J. (2007) "There they go again: The trial bar's quest for the next litigation bonanza." National Legal Center for the Public Interest, January, 11(1): 131 .

Fielding, A. (2008) "Yahoo? Reining in the wild west with the Alien Tort Claims Act." Human Rights Review. 9: 513-523.

Fireman, B. and Gamson, W. A. (1979) "Utilitarian logic in the resource mobilization perspective." In McCarthy, J. D. and Zald, M. N. (Eds.), The dynamics of social movements: Resource mobilization, social control and tactics: 8-44. Cambridge: Winthrop.

Fombrun, C. J. (1996) “Reputation: Realizing value from the corporate image." Boston: Harvard Business School.

Fombrun, C. J. and Shanley, M. (1990) "What's in a name? Reputation building and corporate strategy." Academy of Management Journal, 33: 233-258. 
Fombrun, C. (2001) "Corporate reputations as economic assets.” in Hitt, M., Freeman, R. and Harrison, J. (eds.), Handbook of Strategic Management. Blackwell, Oxford, UK.

Fraas, J. W. and Newman, I. (2003) "Ordinary Least Squares regression, discriminant analysis, and logistic regression: Questions researchers and practitioners should address when selecting an analytic technique." Paper presented at the annual meeting of the Eastern Educational Research Association, Hilton Head Island, February 26-March 1.

Freeman, E. R. (1984) Strategic management: A stakeholder approach. Englewood Cliffs, NJ: Prentice Hall.

Freeman, E. R., Harrison J. S., and Wicks, A. (2007) Managing for Stakeholders: Survival, Reputation, and Success. Yale University Press: New Haven, CT.

Friedman, M. (1962) Capitalism and freedom. Chicago: University of Chicago Press.

Frooman, J. (1999) "Stakeholder influence strategies." Academy of Management Review, 24: 191-205.

Frooman, J. and Murrell, A. J. (2005) "Stakeholder influence strategies: The roles of structural and demographic determinants." Business \& Society, 44(1): 3-31.

Frost, C. (1991) "Loss contingency reports and stock prices: a replication and extension of Banks \& Kinney.” Journal of Accounting Research, 29: 157-168.

Frynas, J. G. (2004) "Social and environmental litigation against transnational firms in Africa." Journal of Modern African Studies, 42(3): 363-388.

Gallagher, K. (2010) "Civil litigation and transnational business: An Alien Tort Statute primer.” Journal of International Criminal Justice, 8(3): 745-767.

Gande, A. and Lewis, C. M. (2009) "Shareholder-initiated class action lawsuits: shareholder wealth effects and industry spillovers." Journal of Financial and Quantitative Analysis, 44(4): 823-850.

Garcia, F. H. and Ewing, A. (2008) "Defending corporate reputation from litigation threats." Strategy \& Leadership, 36(3): 41-45.

Gardberg, N. A. and Fombrun, C. (2006) "Corporate citizenship: creating intangible assets across institutional environments." Academy of Management Review, 31(2):329346.

Gardberg, N. A. and Newburry, W. (2010) "Who boycotts whom? Marginalization, company knowledge, and strategic issues." Business \& Society. 
Godfrey, P. C. (2005) "The relationship between corporate philanthropy and shareholder wealth: A risk management perspective." Academy of Management Review, 30(4): 777798.

Godfrey, P. C., Merrill, C. B. and Hansen, J. M. (2009) "The relationship between corporate social responsibility and shareholder value: an empirical test of the risk management hypothesis." Strategic Management Journal, 30: 425-445.

Goldhaber, M. D. (2008) "Open wounds: Big oil and big mining face a host of allegations that they helped commit human rights abuses." The American Lawyer, 1 October.

Goldhaber, M. D. (2009) "A win for Wiwa, a win for Shell, a win for corporate human rights." The AmLaw Daily, 10 June. Accessed at http://amlawdaily.typepad.com/amlawdaily/2009/06/a-win-for-wiwa-a-win-for-shell-awin-for-corporate-human-rights.html

Goldhaber, M. D. (2010) "The life and death of the corporate alien tort." Americanlawyer.com, 12 October. Accessed at http://www.law.com/jsp/tal/PubArticleTAL.jsp?id=1202473215797\&slreturn=1\&hbxlogi $\underline{\mathrm{n}=1}$

Grosse, R. G. (ed.) (2005) International Business and Government Relations in the $21^{\text {st }}$ Century. Cambridge: Cambridge University Press, 193-216.

Gunningham, N., Kagan, R. A., and Thornton, D. (2004) "Social license and environmental protection: Why businesses go beyond compliance." Law \& Social Inquiry, 29(2): 307-341.

Hart, S. L. and Sharma, S. (2004) "Engaging fringe stakeholders for competitive imagination." Academy of Management Executive, 18(1): 7-18.

Hendry, J. R. (2006). "Taking aim at business: What factors lead environmental nongovernmental organizations to target particular firms?" Business \& Society, 45(1): 47-86.

Henisz, W. J. and Zelner, B. A. (2003) "The Strategic Organization of Political Risks and Opportunities." Strategic Organization 1(4): 451-460.

Henisz, W. J. and Zelner, B. A. (2004) "Political risk management: a strategic perspective.” In T. H. Moran (Ed.), International Political Risk Management: The Brave New World. Washington, D.C: The World Bank Group.

Henisz, W. J. and Zelner, B. A. (2010) "The hidden risks in emerging markets." Harvard Business Review, April, 88-95. 
Henisz, W, E., Mansfield, M. and Von Glinow, M. (2010) "Conflict, Security and Political Risk: International Business in Challenging Times." Journal of International Business Studies, 41(5): 759-764.

Herz, R. L. (2008) "The liberalizing effects of tort: How corporate complicity liability under the Alien Tort Statute advances constructive engagement." Harvard Human Rights Journal, 21: 207-239.

Hillman, A. J. and Hitt, M. A. (1999) "Corporate political strategy formulation: A model of approach, participation, and strategy decisions." Academy of Management Review, 24(4): 825-842.

Hillman, A. J. and Keim, G. D. (2001) "Shareholder value, stakeholder management, and social issues: what's the bottom line?" Strategic Management Journal, 22(2): 125-139.

Hillman, A. J., Shropshire, C., and Cannella, A. A. (2007) "Organizational predictors of women on corporate boards.” Academy of Management Journal, 50: 941-952.

Hischman, A. O. 1970. Exit, voice, and loyalty: Responses to decline in firms, organizations, and states. Cambridge, MA: Harvard University Press.

Holzmeyer, C. (2009) "Human rights in an era of neoliberal globalization: the alien tort claims act and grassroots mobilization in Doe v. Unocal." Law \& Society Review, 43(2): 271-304.

Hufbauer, G. C. (2009) The Alien Tort Statute of 1789: Time for a fresh look. Peterson Institute for International Economics. Policy Brief Number PB 09-9 (May): 1-6.

Hufbauer, G. C. and Mitrokostas, K. (2004) "International implications of the Alien Tort Statute." Journal of International Economic Law, 7(2): 245-262.

Janney, J. J., Dess, G., and Forlani, V. (2009) "Glass houses? Market reactions to firms joining the UN Global Compact." Journal of Business Ethics, 90(3): 407-423.

Jones, G. (2010) "Multinational Strategies and Developing Countries in Historical Perspective.” Harvard Business School Working Paper, 10-076.

Jones, G., Jones, B. and Little, P. (2000) "Reputation as reservoir: Buffering against loss in times of economic crisis." Corporte Reputation Review, 3(1): 21-29.

Jones, T. M. (1991) "Ethical decision-making by individuals in organizations - An issuecontingent model." Academy of Management Review, 20: 404-437.

Julian, S. D., Ofori-Dankwa, J. C., and Justis, R. T. (2008) "Understanding strategic responses to interest group pressures.” Strategic Management Journal, 29: 963-984. 
Kaeb, C. (2008) "Emerging issues of human rights responsibility in the extractive and manufacturing industries: Patterns and liability risks." Northwestern Journal of International Human Rights, 6(2): 327-353.

Kale, P., Dyer, J. H., and Singh, H. (2002) "Alliance capability, stock market response, and long-term alliance success: The role of the alliance function." Strategic Management Journal, 23: 747-767.

Karpoff, J. M. and Lott, J. R. (1993) "The reputational penalty firms bear from committing criminal fraud." Journal of Law and Economics, 36: 757-802.

Kapstein, E. (2006) "Avoiding Unrest in a Volatile Environment." in Mastering Uncertainty, a four-part weekly supplement to The Financial Times, Part 1: "Seeking Shelter from the Storm." 17 March.

Keck, M. E. and Sikkink, K. (1998) Activists Beyond Borders: Advocacy Networks in International Politics. Ithaca: Cornell University Press.

Kendall, B. (2011) "Exxon hit by reversal in human-rights case." Wall Street Journal, 9 July.

Khanna, T., \& Palepu, K. G. (2010) Winning in Emerging Markets: A Road Map for Strategy and Execution. Cambridge: Harvard Business Press.

Kerlinger, F. N. and Pedhazur, E. (1973) Multiple regression in behavioral research. New York: Holt, Rinehart, \& Winston.

King, B. G. (2008) "A political mediation model of corporate response to social activism.” Administrative Science Quarterly, 53: 395 - 421.

King, B. G. (2009) "When markets become contentious.” Contexts, 8(3): 34-39.

King, B. G. and Soule, S. A. (2007) "Social movements as extra-institutional entrepreneurs: The effect of protests on stock price returns." Administrative Science Quarterly, 52: 413-442.

King, B. G. and Pearce, N. A. (2010). "The Contentiousness of Markets: Politics, Social Movements and Institutional Change in Markets." Annual Review of Sociology, 36: 249267.

Klein, N. (1999) No logo: Taking aim at the brand bullies. New York: Picador.

Kobrin, S. J. (1979) "Political Risk: A Review and Reconsideration." Journal of International Business Studies, 10: 67-80. 
Kobrin, S.J. (1982) Managing political risk assessment: strategic response to environmental change. Berkeley: University of California Press.

Kobrin, S. J. (2004) "Oil and Politics: Talisman Energy in Sudan." New York University Journal of International Law and Politics, 36(2/3): 425-456.

Kobrin, S. J. (2005) "Multinational enterprise, public authority, and public responsibility: the case of Talisman Energy and human rights in Sudan." In R. G. Grosse (ed.), International Business and Government Relations in the $21^{s t}$ Century, Cambridge: Cambridge University Press, 193-216.

Koh, H. H. (1998) "The 1998 Frankel Lecture: Brining international human rights home." Houston Law Review.

Koku, P. S. (2006) "An analysis and the effects of class-action lawsuits." Journal of Business Research, 59: 508-515.

Koku, P. S., Akhigbe, A., and Springer, T. M. (1997) "The financial impact of boycotts and threats of boycotts." Journal of Business Research, 40(1): 15-20.

Koku, P. S., Qureshi, A. A., and Akhigbe, A. (2001) "The effects of news on initial corporate lawsuits." Journal of Business Research, 53: 49-55.

Kolker, C. (2006) “Jungle Warfare.” Litigation. http://amlawdaily.typepad.com/amlawdaily/files/junge warfare.pdf

Kourala, A. and Laasonen, S. (2010) "Nongovernmental organizations in business and society, management, and international business research: Review and implications, from 1988 to 2007." Business and Society, 49(1): 35-67.

Kropf, S. E. (2010) "Human rights litigation against multinational energy corporations under the Alien Tort Statute." Energy Litigation, 9(3): 1-5.

Kurlantzick, J. (2004) "Taking the multinationals to court: How the Alien Tort Act promotes human rights." World Policy Journal. Spring: 60-67.

LaFrance and Lehman, (2005) "Corporate awakening - Why (some) corporations embrace public-private partnerships." Business Strategy and the Environment, 14: 216229.

Lambert, R. A. and Larcker, D. F. (1987) "An analysis of the use of accounting and market measures of performance in executive compensation contracts." Journal of Accounting Research, 25, 85-125.

Lange, D., Lee, P. M., and Dai, Y. (2011) “Organizational reputation: A review.” Journal of Management, 37(1): 153-184. 
Laplume, A. O., Sonpar, K., and Litz, R. A. (2008) "Stakeholder theory: reviewing a theory that moves us." Journal of Management, 34(6): 1152-1189.

Larana, E., Johnston, H., and Gusfield, J. R. (1994) New social movements: From ideology to identity. Philadelphia: Temple University Press.

Latham \& Watkins (2010) "Client alert: The steady rise of Alien Tort Claims Act lawsuits and the effect on U.S. companies," Number 1079, 7 September.

Lenox, M. J., Eesley, C. E. (2009) "Private environmental activism and the selection and response of firm targets." Journal of Economics and Management Strategy, 18(1): 45-73.

Lev, B. (2001) Intangibles: Management, Measurement, and Reporting. Brookings Institute.

Love, E. G. and Kraatz, M. S. (2009) "Character, conformity, or the bottom line? How and why downsizing affected corporate reputation." Academy of Management Journal, 52: $314-335$.

Lowery, D. and Brasher, H. (2004) Organized interests and American government. Boston: McGraw Hill.

Lyon, T. (2010) Good Cop Bad Cop - Environmental NGOs and their strategies towards business, Earthscan: Washington.

Mackey, A., Mackey, T. B. and Barney, J. B. (2007) "Corporate social responsibility and firm performance: investor preferences and corporate strategies." Academy of Management Review, 32(3): 817-835.

MacKinlay, A. C. (1997) "Event studies in economics and finance." Journal of Economic Literature, 35: 13-39.

Manhas, R. (2007) “Talisman in Sudan: Impacts of divestment.” Compact Quarterly. March http://www.enewsbuilder.net/globalcompact/e article000775162.cfm?x=b11,0,w

Mankowski, C. (2006) "TIAA-CREF drops Coke from Social Choice Account." Reuters, 18 July.

Mannheim, J. B. (2001) The Death of a Thousand Cuts: Corporate Campaigns and the Attack on the Corporation. Mahwah, NJ: Lawrence Erlbaum.

Margolis, J. D. and Walsh, J. P. (2003) "Misery loves companies: rethinking social initiatives by business." Administrative Science Quarterly, 48(2): 268-305. 
Markwick, S. (1998) "Trends in political risk for corporate investors." In T. H. Moran (ed.), Managing International Political Risk, Malden: Blackwell Publishers.

Markoff, J. (2011) "Suit claims Cisco helped China pursue Falun Gong." The New York Times, 22 May.

Martin, K. D. and Kracher, B. (2008) "A conceptual framework for online business protest tactics and criteria for their effectiveness. Business \& Society, 47, 291-311.

McCann, M. 1994. Rights at work: Pay equity reform and the politics of legal mobilization. Chicago: University of Chicago Press.

McNeil, K., Newman, I., and Kelly, F. J. (1996) Testing research hypotheses with the general linear model. Carbondale: Southern Illinois University Press.

McWilliams, A. and Siegel, D. (1997) "Event studies in management research: theoretical and empirical issues." Academy of Management Journal, 40(3): 626-657.

Melucci, A. (1995) “The process of collective identity." In Johnston, H. and Klandermans, B. (Eds.), Social movements and culture (pp. 41-64). Minneapolis: University of Minnesota.

Mertler, C. A. and Vannatta, R. A. (2005) Advanced and multivariate statistical methods (3e). Glendale, CA: Pyrczak Publishing.

Miles, R. H. (1987) Managing the corporate social environment: A grounded theory. Englewood Cliffs, NJ: Prentice Hall.

Mitchell, R. K., Agle, B. R., and Wood, D. J. (1997) "Toward a theory of stakeholder identification and salience: Defining the principle of who and what really counts." Academy of Management Review, 22: 853-886.

O’Rourke, D. (2005) "Market movements: Non governmental organization strategies to influence global production and consumption," Journal of Industrial Ecology, 9(1-2): 115-128.

Oetzel, J. (2005) "Smaller may be beautiful but is it more risky? Assessing and managing political and economic risk in Costa Rica.” International Business Review, 14: 765-790

Oetzel, J., Getz, K. A., and Ladek, S. (2007) "The role of multinational enterprises in responding to violent conflict: A conceptual model and framework for research." American Business Law Journal, 44(2): 331-358.

Olson, M. J. (1965) The logic of collective action. Cambridge, MA: Harvard University Press. 
Orlitzky, M., Schmidt, F., and Rynes, S. (2003) "Corporate social and financial performance: A meta-analysis.” Organization Studies, 24: 403-441.

O'Rourke, D. (2005) "Market movements: nongovernmental organization strategies to influence global production and consumption." Journal of Industrial Ecology, 9.1-2:11528.

Oxley, J. and Schneitz, K. (2001) “Globalization derailed? Multinational investors' response to the 1997 denial of fast-track negotiating authority." Journal of International Business Studies, 32(3): 479-496.

Peterson, M. J. (1992) "Transnational activity, international society and world politics." Millennium: Journal of International Studies, 21(3): 371-388.

Pfeffer, J. and Salancik, G. R. (1978) The external control of organizations: A resource dependence perspective. New York: Harper \& Row.

Proffitt W. T. Jr, and Spicer A. (2006) Shaping the shareholder activism agenda: Institutional investors and global social issues. Strategic Organization 4 (2): 165-190.

Pruitt, S. W. and Friedman, M. (1986) "Determining the effectiveness of consumer boycotts: A stock price analysis of their impact on corporate targets." Journal of Consumer Policy, 9: 375-387.

Pruitt, S. W., Wei, K. C. J., and White, R. E. (1988) "The impact of union-sponsored boycotts on the stock prices of target firms." Journal of Labor Research, 9(3): 285-289.

Rangan, V. K. and Barton, B. (2010) "Breaking new ground: the emerging frontier of CSR in the extractive sector," in N. C. Smith, C. B. Bhattacharaya, D. Vogel, \& D. I. Levine (eds.), Global challenges in responsible business. New York: Cambridge University Press.

Rao, H. (2001) Gadflies and corporate behavior. Working paper, Emory University, Atlanta, GA.

Rao, H. (2009) Market rebels: How activists make or break radical innovations. Princeton, NJ: Princeton University Press.

Rees, C. (2010) "Mediation in business-related human rights disputes: Objections, opportunities and challenges." Corporate Social Responsibility Initiative Working Paper No. 56. Cambridge, MA: John F. Kennedy School of Government, Harvard University.

Rehbein, K., Waddock, S. and Graves, S. B. (2004) "Understanding shareholder activism: Which corporations are targeted?” Business \& Society, 43: 239-268. 
Reid, E. M. and Toffel, M. W. (2009) "Responding to Public and Private Politics: Corporate Disclosure of Climate Change Strategies." Strategic Management Journal, 30: 1157-1178.

Ricart, J. E., Enright, M. J., Ghemawat, P., Hart, S. L., and Khanna, T. (2004). "New frontiers in international strategy." Journal of International Business Studies, 35(3): 175200.

Rindova, V. P., Pollock, T. G., Hayward, M. L. A. (2006) "Celelebrity firms: The social construction of market popularity." The Academy of Management Review, 31(1): 50-71.

Rindova, V. P., Williamson, I. O., Petkova, A. P., and Sever, J. M. (2005) "Being good or being known: An empirical examination of the dimensions, antecedents, and consequences of organizational reputation." The Academy of Management Journal, 48(6): 1033-1049.

Risse, T., Ropp, S. and Sikkink, K. (Eds.) (1999) The Power of Human Rights: International norms and domestic change. New York: Cambridge University Press.

Rivoli, P. and Salorio, E. (1996) "Foreign direct investment and investment under uncertainty." Journal of International Business Studies, 27(2): 335-357.

Roberts, P. W. and Dowling, G. R. (2002) "Corporate reputation and sustained superior financial performance.” Strategic Management Journal, 23: 1077-1093.

Robock, S.H. (1971) "Political risk identification and assessment." Journal of World Business, 6(4): 6-20.

Rondinelli, D. A. and London, T. (2003) "How corporations and environmental groups cooperate: Assessing cross-sector alliances and collaborations." The Academy of Management Executive, 17(1): 61-76.

Rowley T. J. and Moldoveanu, M. (2003) "When will stakeholder groups act? An interest- and identity based model of stakeholder group mobilization." Academy of Management Review 28 (2): 204-219.

Rowley, T. and S. Berman (2000) "A brand new brand of corporate social performance." Business and Society, 39(4): 397-418.

Russo, M. V. and Fouts, P. A. (1997) "A resource-based perspective on corporate environmental performance and profitability." Academy of Management Journal, 40(3): 534-559.

Sabate, J. M. F., and Puente, E. Q. 2003. "Empirical analysis of the relationship between corporate reputation and financial performance: A survey of the literature." Corporate Reputation Review, 6: 166-177. 
Salancik, G. R. (1979) "Interorganizational dependence and responsiveness to affirmative action: The case of women and defense contractors." Academy of Management Journal, 22: 375 .

Savage, G., Nix, T., Whitehead, C., and Blair, J. (1991) "Strategies for assessing and managing stakeholders." Academy of Management Executive, 5(2): 61-75.

Schnietz, K. E. and Epstein M. J. (2005) "Exploring the financial value of a reputation for corporate social responsibility during a crisis." Corporate Reputation Review, 7(4): 327345.

Schoen, E. J., Falchek, J. S. and Hogan, M. M. (2005) "The Alien Tort Claims Act of 1789: Globalization of business requires globalization of law and ethics." Journal of Business Ethics, 62: 41-56.

Schrage, E. (2003) "Judging corporate accountability in the global economy." Columbia Journal of Transnational Law, 42: 153-176.

Scott, W. R. (2001) Institutions and organizations. Thousand Oaks, CA: Sage.

Shamir, R. (2004) "Between self-regulations and the Alien Tort Claims Act: On the contested concept of corporate social responsibility." Law \& Society Review, 38(4): 635664.

Shamir, R. (2010) "Capitalism, Governance, and Authority: The Case of Corporate Social Responsibility." Annual Review of Law and Social Science, 6: 531-53.

Sharma, S. and Henriques, I. (2005) "Stakeholder influences on sustainability practices in the Canadian forest products industry."Strategic Management Journal, 26: 159-181.

Sheffi, Y. (2005) The resilient enterprise. Boston: MIT Press.

Shleifer, A. (2000) Inefficient Markets: An Introduction to Behavioral Finance (Clarendon Lectures in Economics). Oxford University Press: Oxford, UK.

Sikkink, K. (1993) "Human rights, principled issue-networks, and sovereignty in Latin America.” International Organization, 47(3): 411-441.

Simon, J. D. (1984) "Political risk assessment: past trends and future prospects." Journal of International Business Studies, 15(3): 123-143.

Smith, J., Chatfield, C., and Pagnucco, R. (eds) (1997) Transnational social movements and global politics: Solidarity beyond the state. Syracuse: Syracuse University Press.

Smith, N. C., \& Cooper-Martin, E. 1997. Ethics and target marketing: The role of product harm 
and consumer vulnerability. Journal of Marketing, 61:1-20

Soule, S. A. (2009) Contention and corporate social responsibility. New York: Cambridge University Press.

Spar, D. L. and La Mure, L. T. (2003) "The power of activism: assessing the impact of NGOs of global business." California Management Review, 45: 78-101.

Staw, B. M. and Epstein, L. D. 2000. What bandwagons bring: Effects of popular management techniques on corporate performance, reputation, and CEO pay. Administrative Sciences Quarterly, 45: 523-556.

Stempel, J. (2011a) "Daimler must face Argentina abuse lawsuit in U.S." Thompson Reuters News \& Insight, 18 May.

Stempel, J. (2011b) “Indonesia torture case vs Exxon Mobil revived.” Reuters, 8 July.

Strike, V. M., Gao, J. and Bansal, P. (2006) "Being Good While Being Bad: Social Responsibility and the International Diversification of US Firms." Journal of International Business Studies, 37(6): 850-862.

Suchman, M. C. 1995. Managing legitimacy: Strategic and institutional approaches. Academy of Management Review, 20: 571-610.

Tabachnick, B. G., and Fidell, L. S. (2007) Using Multivariate Statistics, 5th ed. Boston: Allyn and Bacon.

Tarrow, S. (2005) The new transnational activism. Cambridge: Cambridge University Press.

Teegen, H., Doh, J. P. and Vachani, S. (2004) "The importance of nongovernmental organizations (NGOs) in global governance and value creation: An international business research agenda." Journal of International Business Studies, 35: 463-483.

Turban, D. B. and Greeening, D. W. (1997) "Corporate social performance and organizational attractiveness to prospective employees." Academy of Management Journal, 40(3): 658-672.

Vogel, D. (2005) The market for virtue. Washington, DC: The Brookings Institution.

Vogel, D. (2008) "Private global business regulation." Annual Review of Political Science, 11: 261-282.

Vogel, D. (2010) "The Private regulation of global corporate conduct: Achievements and limitations." Business and Society, 49(1): 68-87. 
Waddock, S. A. and Graves, S. B. (1997) "The corporate social performance-financial performance link.” Strategic Management Journal, 18(4): 303-319.

Weisbrod, B. (1998) To profit or not to profit. Chicago: Northwestern University Press.

Wells, L.T. Jr. (1998). God and fair competition: Does the foreign direct investor face still other risks in emerging markets?" In T. H. Moran (Ed.). Managing international political risk. Malden: Blackwell Publishers.

Whetten, D. A., Rands, G., and Godfrey, P. (2002) "What are the responsibilities of business to society?" In Pettigrew, A., Thomas, H., and Whittington, R. (Eds.), Handbook of strategy and management (pp. 373-408). London: Sage Ltd.

Williams, C. A. and Conley, J. M. (2007) "Is there an emerging fiduciary duty to consider human rights?" University of Cincinnati Law Review, 74(1): 75-104.

Williamson, H. (2009) "Time to redraw the battle line." Financial Times-Business Education. Published on December 30, 2009.

Yaziji, M. (2004) “Turning gadflies into allies." Harvard Business Review 82(2): 110115.

Yaziji, M. (2005). "Toward a theory of Social Risk." International Studies of Management and Organization, 34 (4): 87-107.

Yaziji, M. and Doh, J. P. (2009). NGOs and corporations: Conflict and collaboration. New York: Cambridge University Press.

Zajac, E. J. and Westphal, J. D. (2004) "The social construction of value: Institutionalization and learning perspectives on stock market reactions." American Sociological Review, 69: 433-457. 


\section{APPENDICES}

APPENDIX A - List of ATS Cases and Dates by Firm

\begin{tabular}{|c|c|}
\hline Corporation & Date \\
\hline $\begin{array}{l}\text { Abercrombie \& } \\
\text { Fitch }\end{array}$ & $3 / 3 / 2000$ \\
\hline Anglo American & $4 / 4 / 2003$ \\
\hline $\begin{array}{l}\text { Archer Daniels } \\
\text { Midland }\end{array}$ & 7/15/2005 \\
\hline Barclay's PLC & $11 / 12 / 2002$ \\
\hline BP & $11 / 12 / 2002$ \\
\hline Brylane Inc. & 1/13/1999 \\
\hline $\begin{array}{l}\text { Caci International, } \\
\text { Inc. }\end{array}$ & 6/9/2004 \\
\hline $\begin{array}{l}\text { Caci International, } \\
\text { Inc. }\end{array}$ & $7 / 1 / 2008$ \\
\hline Caterpillar & 3/15/2005 \\
\hline Chevron & $5 / 28 / 1999$ \\
\hline
\end{tabular}




\begin{tabular}{|c|c|}
\hline Chevron & $11 / 12 / 2002$ \\
\hline $\begin{array}{l}\text { Chiquita Brands } \\
\text { Intl }\end{array}$ & $6 / 7 / 2007$ \\
\hline $\begin{array}{l}\text { Chiquita Brands } \\
\text { Intl }\end{array}$ & $6 / 14 / 2007$ \\
\hline $\begin{array}{l}\text { Chiquita Brands } \\
\text { Intl }\end{array}$ & $7 / 19 / 2007$ \\
\hline $\begin{array}{l}\text { Chiquita Brands } \\
\text { Intl }\end{array}$ & $11 / 14 / 2007$ \\
\hline $\begin{array}{l}\text { Chiquita Brands } \\
\text { Intl }\end{array}$ & $8 / 13 / 2008$ \\
\hline $\begin{array}{l}\text { Chiquita Brands } \\
\text { Intl }\end{array}$ & $4 / 14 / 2010$ \\
\hline Citigroup & $6 / 17 / 2002$ \\
\hline Citigroup & $11 / 12 / 2002$ \\
\hline Coca-Cola & $7 / 20 / 2001$ \\
\hline Coca-Cola & $11 / 10 / 2005$ \\
\hline Credit Suisse & $6 / 17 / 2002$ \\
\hline Cutter \& Buck, Inc & $1 / 13 / 1999$ \\
\hline Daimler-Chrysler & $8 / 19 / 2002$ \\
\hline
\end{tabular}




\begin{tabular}{|c|c|}
\hline Daimler-Chrysler & $11 / 12 / 2002$ \\
\hline Daimler-Chrysler & $1 / 14 / 2004$ \\
\hline $\begin{array}{l}\text { Dayton Hudson } \\
\text { Corp }\end{array}$ & $1 / 13 / 1999$ \\
\hline Deutsche Bank & $11 / 12 / 2002$ \\
\hline $\begin{array}{l}\text { Donna Karen } \\
\text { International }\end{array}$ & $1 / 13 / 1999$ \\
\hline Dow Chemical Co & $2 / 2 / 2004$ \\
\hline Dow Chemical Co & $9 / 26 / 2006$ \\
\hline Dress Barn & $1 / 13 / 1999$ \\
\hline Exxon Mobil Corp & $6 / 21 / 2001$ \\
\hline Exxon Mobil Corp & $8 / 2 / 2002$ \\
\hline Exxon Mobil Corp & $11 / 12 / 2002$ \\
\hline Fluor Corp. & $11 / 12 / 2002$ \\
\hline Fluor Corp. & $4 / 4 / 2003$ \\
\hline Ford Motor Co. & $11 / 12 / 2002$ \\
\hline
\end{tabular}




\begin{tabular}{|c|c|}
\hline Freeport-McMoran & $4 / 29 / 1996$ \\
\hline Gap, Inc & 1/13/1999 \\
\hline General Motors & $11 / 12 / 2002$ \\
\hline Gold Fields Ltd & $5 / 2 / 2003$ \\
\hline Gymboree Corp. & 1/13/1999 \\
\hline Honeywell Int'I & $8 / 2 / 2002$ \\
\hline $\begin{array}{l}\text { Hewlett Packard } \\
\text { Co }\end{array}$ & $9 / 27 / 2002$ \\
\hline IBM & $2 / 12 / 2001$ \\
\hline IBM & $6 / 24 / 2002$ \\
\hline IBM & $11 / 12 / 2002$ \\
\hline $\begin{array}{l}\text { J.C. Penney } \\
\text { Company, Inc }\end{array}$ & $1 / 13 / 1999$ \\
\hline J.P. Morgan Chase & $11 / 12 / 2002$ \\
\hline $\begin{array}{l}\text { Jones Apparel } \\
\text { Group }\end{array}$ & $1 / 13 / 1999$ \\
\hline KBR, Inc & $1 / 13 / 1999$ \\
\hline
\end{tabular}




\begin{tabular}{|c|c|}
\hline Limited, Inc & 1/13/1999 \\
\hline Liz Claiborne, Inc & $1 / 13 / 1999$ \\
\hline $\begin{array}{l}\text { May Deparment } \\
\text { Stores Company }\end{array}$ & 6/13/1999 \\
\hline Monsanto & $2 / 4 / 2004$ \\
\hline $\begin{array}{l}\text { Newmont Mining } \\
\text { Corp. }\end{array}$ & $6 / 4 / 2002$ \\
\hline Nokia Corp & $8 / 20 / 2010$ \\
\hline Nordstrom, Inc & $1 / 13 / 1999$ \\
\hline $\begin{array}{l}\text { Occidental } \\
\text { Petroleum }\end{array}$ & $4 / 24 / 2003$ \\
\hline $\begin{array}{l}\text { Occidental } \\
\text { Petroleum }\end{array}$ & $2 / 4 / 2004$ \\
\hline $\begin{array}{l}\text { Occidental } \\
\text { Petroleum }\end{array}$ & $8 / 11 / 2006$ \\
\hline Oshkosh B'Gosh & $1 / 13 / 1999$ \\
\hline Pfizer & $8 / 30 / 2001$ \\
\hline $\begin{array}{l}\text { Phillips-Van } \\
\text { Heusen }\end{array}$ & 6/13/1999 \\
\hline Rio Tinto & $9 / 6 / 2000$ \\
\hline
\end{tabular}




\begin{tabular}{|c|c|}
\hline Rio Tinto & $11 / 12 / 2002$ \\
\hline Polo Ralph Lauren & 1/13/1999 \\
\hline $\begin{array}{l}\text { Royal Dutch } \\
\text { Petroleum }\end{array}$ & $11 / 8 / 1996$ \\
\hline $\begin{array}{l}\text { Royal Dutch } \\
\text { Petroleum }\end{array}$ & $8 / 2 / 2002$ \\
\hline $\begin{array}{l}\text { Royal Dutch } \\
\text { Petroleum }\end{array}$ & $9 / 23 / 2002$ \\
\hline $\begin{array}{l}\text { Royal Dutch } \\
\text { Petroleum }\end{array}$ & $11 / 12 / 2002$ \\
\hline Sasol Ltd & $4 / 7 / 2003$ \\
\hline $\begin{array}{l}\text { Sears Roebuck \& } \\
\text { Co }\end{array}$ & $6 / 13 / 1999$ \\
\hline Siemens A G & $8 / 20 / 2010$ \\
\hline $\begin{array}{l}\text { Southern Peru } \\
\text { Copper }\end{array}$ & $12 / 28 / 2000$ \\
\hline Talbots, Inc & $3 / 3 / 2000$ \\
\hline Talisman & $11 / 7 / 2001$ \\
\hline Texaco & $11 / 4 / 1993$ \\
\hline Titan Corp. & $6 / 9 / 2004$ \\
\hline
\end{tabular}




\begin{tabular}{|c|c|}
\hline $\begin{array}{l}\text { Tommy Hilfiger } \\
\text { USA Inc. }\end{array}$ & $1 / 13 / 1999$ \\
\hline Total Fina ELF SA & $11 / 12 / 2002$ \\
\hline UBS & $6 / 17 / 2002$ \\
\hline UBS & $11 / 12 / 2002$ \\
\hline Union Carbide & $11 / 15 / 1999$ \\
\hline Unisys & $1 / 13 / 1999$ \\
\hline Unocal & $10 / 3 / 1996$ \\
\hline $\begin{array}{l}\text { Wal-Mart Stores, } \\
\text { Inc }\end{array}$ & $1 / 13 / 1999$ \\
\hline $\begin{array}{l}\text { Wal-Mart Stores, } \\
\text { Inc }\end{array}$ & $9 / 13 / 2005$ \\
\hline Warnaco, Inc & 1/13/1999 \\
\hline Xerox & $9 / 27 / 2002$ \\
\hline Yahoo! & $4 / 18 / 2007$ \\
\hline
\end{tabular}


APPENDIX B - List of U.S. Extractive Firms Sued Under ATS, 1996-2010

\begin{tabular}{|c|c|c|c|c|}
\hline Firm & Year & Case & Country & Allegations \\
\hline CHEVRON CORP & 1999 & $\begin{array}{l}\text { Bowoto, et al. v. Chevron, } \\
\text { et al. }\end{array}$ & Nigeria & $\begin{array}{l}\text { Plaintiffs allege that the } \\
\text { defendants provided } \\
\text { assistance to and } \\
\text { participated in military } \\
\text { raids by the Nigerian } \\
\text { military against } \\
\text { demonstrators on a } \\
\text { Chevron oil rig. }\end{array}$ \\
\hline CHEVRON CORP & 2002 & $\begin{array}{l}\text { Khulumani Group et al. v. } \\
\text { Barclay Nat'l Bank et al. }\end{array}$ & South Africa & $\begin{array}{l}\text { Plaintiffs allege that the } \\
\text { defendants, which include } \\
\text { businesses from a variety } \\
\text { of sectors, supported } \\
\text { apartheid-related race } \\
\text { discrimination and other } \\
\text { human rights abuses, } \\
\text { including murders, } \\
\text { massacres, imprisonment, } \\
\text { torture, forced removals, } \\
\text { and theft of assets. }\end{array}$ \\
\hline $\begin{array}{l}\text { EXXON MOBIL } \\
\text { CORP }\end{array}$ & 2001 & $\begin{array}{l}\text { John Doe I, et al. v. Exxon } \\
\text { Mobil Corp. }\end{array}$ & Indonesia & $\begin{array}{l}\text { Plaintiffs allege that firm } \\
\text { was vicariously liable for } \\
\text { murder, genocide, torture, } \\
\text { kidnapping, and other } \\
\text { crimes against humanity } \\
\text { allegedly committed by } \\
\text { the Indonesian military in } \\
\text { Aceh, in northern Sumatra, } \\
\text { in the course of fighting a } \\
\text { civil war and protecting } \\
\text { the firm's gas production } \\
\text { facilities. }\end{array}$ \\
\hline $\begin{array}{l}\text { EXXON MOBIL } \\
\text { CORP }\end{array}$ & 2002 & $\begin{array}{l}\text { Khulumani Group et al. v. } \\
\text { Barclay Nat'I Bank et al. }\end{array}$ & South Africa & $\begin{array}{l}\text { Plaintiffs allege that the } \\
\text { defendants, which include } \\
\text { businesses from a variety } \\
\text { of sectors, supported } \\
\text { apartheid-related race } \\
\text { discrimination and other } \\
\text { human rights abuses, } \\
\text { including murders, } \\
\text { massacres, imprisonment, } \\
\text { torture, forced removals, } \\
\text { and theft of assets. }\end{array}$ \\
\hline FLUOR CORP & 2002 & $\begin{array}{l}\text { Khulumani Group et al. v. } \\
\text { Barclay Nat'l Bank et al. }\end{array}$ & South Africa & $\begin{array}{l}\text { Plaintiffs allege that the } \\
\text { defendants, which include } \\
\text { businesses from a variety } \\
\text { of sectors, supported } \\
\text { apartheid-related race }\end{array}$ \\
\hline
\end{tabular}




\begin{tabular}{|c|c|c|c|c|}
\hline & & & & $\begin{array}{l}\text { discrimination and other } \\
\text { human rights abuses, } \\
\text { including murders, } \\
\text { massacres, imprisonment, } \\
\text { torture, forced removals, } \\
\text { and theft of assets. }\end{array}$ \\
\hline $\begin{array}{l}\text { FREEPORT- } \\
\text { MCMORAN }\end{array}$ & 1996 & $\begin{array}{l}\text { Beanal, et al. v. Freeport- } \\
\text { McMoran, Inc. }\end{array}$ & Indonesia & $\begin{array}{l}\text { Plaintiffs alleged that } \\
\text { defendant was liable for } \\
\text { environmental abuses, } \\
\text { human rights violations } \\
\text { and genocide, in } \\
\text { connection with its } \\
\text { copper, gold and silver } \\
\text { mining activities in } \\
\text { Indonesia. }\end{array}$ \\
\hline KBR INC & 2008 & $\begin{array}{l}\text { Adhikari v. Daoud \& } \\
\text { Partners v. KRR }\end{array}$ & Iraq & $\begin{array}{l}\text { Plaintiffs alleged that the } \\
\text { defendant engaged in an } \\
\text { illegal human-trafficking } \\
\text { scheme involving } 12 \\
\text { Nepali men, ages } 18-27, \\
\text { who were recruited in } \\
\text { Nepal to work in luxury } \\
\text { hotels in Jordan, but were } \\
\text { instead sent against their } \\
\text { will to work in a U.S. } \\
\text { military base in Iraq. The } \\
\text { Nepalese workers were } \\
\text { kidnapped and killed en } \\
\text { route to the base by } \\
\text { Islamic militants. }\end{array}$ \\
\hline $\begin{array}{l}\text { NEWMONT } \\
\text { MINING CORP }\end{array}$ & 2002 & $\begin{array}{l}\text { Maugein v. Newmont } \\
\text { Mining Corp. et al. }\end{array}$ & Peru & $\begin{array}{l}\text { Plaintiffs sought redress } \\
\text { for a toxic mercury spill by } \\
\text { a trucking contractor of } \\
\text { the firm that injured more } \\
\text { than } 1,000 \text { indigenous } \\
\text { villagers from the Andean } \\
\text { countryside. }\end{array}$ \\
\hline $\begin{array}{l}\text { OCCIDENTAL } \\
\text { PETROLEUM CORP }\end{array}$ & 2003 & $\begin{array}{l}\text { Mujica v. Occidental } \\
\text { Petroleum, et al. }\end{array}$ & Colombia & $\begin{array}{l}\text { Plaintiffs alleged that the } \\
\text { firm provided support to } \\
\text { the Colombian military in } \\
\text { return for protecting } \\
\text { Occidental's pipeline in } \\
\text { Colombia. Support was } \\
\text { instrumental in the } \\
\text { planning and execution of } \\
\text { a helicopter-borne cluster } \\
\text { bomb attack that killed } \\
\text { members of plaintiff's } \\
\text { family. }\end{array}$ \\
\hline $\begin{array}{l}\text { OCCIDENTAL } \\
\text { PETROLEUM CORP }\end{array}$ & 2004 & $\begin{array}{l}\text { Vietnam Association for } \\
\text { the Victims of Agent } \\
\text { Orange/Dioxan v. The Dow }\end{array}$ & Vietnam & $\begin{array}{l}\text { Plaintiffs sought damages } \\
\text { from U.S. chemical } \\
\text { manufacturers for the }\end{array}$ \\
\hline
\end{tabular}




\begin{tabular}{|c|c|c|c|c|}
\hline & & Chemical Company et al. & & $\begin{array}{l}\text { Vietnamese victims of } \\
\text { Agent Orange, a toxic } \\
\text { defoliant used by the U.S. } \\
\text { military during the } \\
\text { Vietnam War. }\end{array}$ \\
\hline $\begin{array}{l}\text { OCCIDENTAL } \\
\text { PETROLEUM CORP }\end{array}$ & 2006 & $\begin{array}{l}\text { Shiguago v. Occidental } \\
\text { Petroleum Corp. }\end{array}$ & Ecuador & $\begin{array}{l}\text { Plaintiffs alleged that the } \\
\text { firm is complicit in human } \\
\text { rights violations } \\
\text { committed by paramilitary } \\
\text { groups that guard the } \\
\text { company's pipeline. }\end{array}$ \\
\hline $\begin{array}{l}\text { OCCIDENTAL } \\
\text { PETROLEUM CORP }\end{array}$ & 2007 & $\begin{array}{l}\text { Carijano v Occidental } \\
\text { Petroleum Corp. }\end{array}$ & Peru & $\begin{array}{l}\text { Plaintifs alleged that the } \\
\text { firm's illegal disposal of } \\
\text { toxic wastEwater in the } \\
\text { Peruvian Amazon resulted } \\
\text { in severe contamination of } \\
\text { the land and rivers in the } \\
\text { regikn, causing adverse } \\
\text { health effects including } \\
\text { lead and cadmium } \\
\text { poisoning, and damage to } \\
\text { llvElihoOds. }\end{array}$ \\
\hline $\begin{array}{l}\text { SOUTHERN } \\
\text { COPPER CORP }\end{array}$ & 2000 & $\begin{array}{l}\text { Flores v. Southern Peru } \\
\text { Copper Corp. }\end{array}$ & Peru & $\begin{array}{l}\text { Plaintiffs, residejts of Peru, } \\
\text { alleged that pollution from } \\
\text { the defendant flrm's } \\
\text { miNing, refining, and } \\
\text { smelting opepatiojs caused } \\
\text { a variety of serious human } \\
\text { health problems including } \\
\text { respiratory diseases. }\end{array}$ \\
\hline UNOCAL CORP & 1996 & Doe, et al. v. Unocal Corp. & Burma & $\begin{array}{l}\text { Providing support to the } \\
\text { Burmese military which } \\
\text { allegedly engaged in } \\
\text { forced relocation of } \\
\text { villages, used forced labor, } \\
\text { and engaged in torture, } \\
\text { extrajudicial killings, and } \\
\text { rape in furtherance of a } \\
\text { natural gas pipeline } \\
\text { project. }\end{array}$ \\
\hline
\end{tabular}


APPENDIX C - List of U.S. Extractive Firms Not Sued Under ATS, 1996-2010 (Comparison Sample)

\begin{tabular}{|c|c|c|}
\hline Firm & SIC Code & Description \\
\hline ALCOA INC & 33 & Primary Metal Industries \\
\hline ANADARKO PETROLEUM CORP & 13 & Oil and Gas Extraction \\
\hline APACHE CORP & 13 & Oil and Gas Extraction \\
\hline BAKER HUGHES INC & 35 & Industrial Machinery and Equipment \\
\hline $\begin{array}{l}\text { CAMERON INTERNATIONAL } \\
\text { CORP }\end{array}$ & 35 & Industrial Machinery and Equipment \\
\hline CHESAPEAKE ENERGY CORP & 13 & Oil and Gas Extraction \\
\hline CIMAREX ENERGY CO & 13 & Oil and Gas Extraction \\
\hline CONCHO RESOURCES INC & 13 & Oil and Gas Extraction \\
\hline CONOCOPHILLIPS & 29 & Petroleum Refining \\
\hline CONSOL ENERGY INC & 12 & Coal Mining \\
\hline CONTINENTAL RESOURCES INC & 13 & Oil and Gas Extraction \\
\hline DENBURY RESOURCES INC & 13 & Oil and Gas Extraction \\
\hline DEVON ENERGY CORP & 13 & Oil and Gas Extraction \\
\hline EI PASO ENERGY & 49 & Electric, Gas, and Sanitary Services \\
\hline EOG RESOURCES INC & 13 & Oil and Gas Extraction \\
\hline EXCO RESOURCES INC & 13 & Oil and Gas Extraction \\
\hline FMC TECHNOLOGIES INC & 35 & Industrial Machinery and Equipment \\
\hline HALLIBURTON CO & 13 & Oil and Gas Extraction \\
\hline HESS CORP & 29 & Petroleum and Coal Products \\
\hline $\begin{array}{l}\text { JACOBS ENGINEERING GROUP } \\
\text { INC }\end{array}$ & 16 & Heavy Construction Except Building \\
\hline MARATHON OIL CORP & 29 & Petroleum and Coal Products \\
\hline MURPHY OIL CORP & 29 & Petroleum and Coal Products \\
\hline
\end{tabular}




\begin{tabular}{|l|l|l|}
\hline NATIONAL OILWELL VARCO INC & 35 & Industrial Machinery and Equipment \\
\hline NEWFIELD EXPLORATION CO & 13 & Oil and Gas Extraction \\
\hline NOBLE ENERGY INC & 13 & Oil and Gas Extraction \\
\hline PEABODY ENERGY CORP & 12 & Bituminous Coal/Lignite Surface Mining \\
\hline $\begin{array}{l}\text { PIONEER NATURAL RESOURCES } \\
\text { CO }\end{array}$ & 13 & Oil and Gas Extraction \\
\hline QEP RESOURCES INC & 13 & Oil and Gas Extraction \\
\hline SOUTHWESTERN ENERGY CO & 49 & Electric, Gas, and Sanitary Services \\
\hline SPECTRA ENERGY CORP & 49 & Electric, Gas, and Sanitary Services \\
\hline SUNOCO INC & 29 & Petroleum and Coal Products \\
\hline TESORO CORP & 29 & Petroleum and Coal Products \\
\hline ULTRA PETROLEUM CORP & 13 & Crude Petroleum and Natural Gas \\
\hline VALERO ENERGY CORP & 29 & Petroleum and Coal Products \\
\hline WALTER ENERGY INC & 12 & Coal Mining \\
\hline WHITING PETROLEUM CORP & 13 & 49 \\
\hline WILLIAMS COS INC & & Eil and Gas Extraction \\
\hline
\end{tabular}


VITA

\section{DAVID ADAM WERNICK}

June 27, 1966

$1984-1988$

1993

1994-1997

$1997-2000$

2002-Present
Born, Boston, Massachusetts

B.A., Political Science

Tulane University

New Orleans, Louisiana

M.A., International Studies

Florida International University

Miami, Florida

Managing Editor

Latin America Advisor

New York, New York

Communications Director

Americas Society/Council of the Americas

New York, New York

Instructor

Department of Management \& Int'1 Business

Florida International University

Miami, Florida

\section{PUBLICATIONS}

Chambers, D., Wernick, D., Zdanowicz, J. and Von Glinow, M. A. (2010). How Dangerous Are Measurement Errors to Homeland Security?

Thunderbird International Business Review, 52(6): 553-569.

Wernick, D., and Von Glinow, M. A. (Forthcoming, 2012). Reflections on the Evolving Terrorist Threat to Luxury Hotels: A Case Study on Marriott International, Thunderbird International Business Review. 